Equal Opportunities and Ethnic Inequality in

\title{
European Labour Markets
}

Discrimination, Gender and

Policies of Diversity

KAREN KRAAL, JUDITH ROOSBLAD

$\&$ JOHN WRENCH (EDS.) 
Equal Opportunities and Ethnic Inequality in European Labour Markets 


\section{IMISCOE}

International Migration, Integration and Social Cohesion in Europe

The IMISCOE Network of Excellence unites over 500 researchers from European institutes specialising in studies of international migration, integration and social cohesion. The Network is funded by the Sixth Framework Programme of the European Commission on Research, Citizens and Governance in a Knowledge-Based Society. Since its foundation in 2004, IMISCOE has developed an integrated, multidisciplinary and globally comparative research project led by scholars from all branches of the economic and social sciences, the humanities and law. The Network both furthers existing studies and pioneers new research in migration as a discipline. Priority is also given to promoting innovative lines of inquiry key to European policymaking and governance.

The IMISCOE-Amsterdam University Press Series was created to make the Network's findings and results available to researchers, policymakers and practitioners, the media and other interested stakeholders. High-quality manuscripts authored by IMISCOE members and cooperating partners are published in one of four distinct series.

IMISCOE RESEARCH advances sound empirical and theoretical scholarship addressing themes within IMISCOE's mandated fields of study.

IMISCOE REPORTS disseminates Network papers and presentations of a time-sensitive nature in book form.

IMISCOE DISSERTATIONS presents select PhD monographs written by IMISCOE doctoral candidates.

IMISCOE TEXTBOOKS produces manuals, handbooks and other didactic tools for instructors and students of migration studies.

IMISCOE Policy Briefs and more information on the Network can be found at www.imiscoe.org. 


\section{Equal Opportunities and Ethnic Inequality in European Labour Markets}

Discrimination, Gender and Policies of Diversity

edited by Karen Kraal, Judith Roosblad and John Wrench 
Cover design: Studio Jan de Boer, Amsterdam Layout: The DocWorkers, Almere

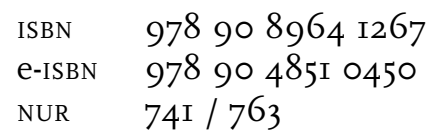

(C) Karen Kraal, Judith Roosblad and John Wrench / Amsterdam University Press, Amsterdam 2009

All rights reserved. Without limiting the rights under copyright reserved above, no part of this book may be reproduced, stored in or introduced into a retrieval system, or transmitted, in any form or by any means (electronic, mechanical, photocopying, recording or otherwise) without the written permission of both the copyright owners and the authors of the book. 


\section{Contents}

Preface

I The ideal of equal opportunities and the practice of unequal chances

Karen Kraal, John Wrench, Judith Roosblad and Patrick Simon Introduction

Democratic states' idealism versus reality

Explaining unequal opportunities

How can societies combat discrimination and create equal opportunities?

The focus and organisation of this book

The role for future research

2 Ethnic inequality and discrimination in the labour market

Angela Nilsson and John Wrench

Introduction

Comparative data on employment rates

Data on inequality in working conditions

Evidence of discrimination

Types of discrimination

Conclusions

3 Migrant and minority women, inequalities and discrimination in the labour market

Eleonore Kofman, Judith Roosblad and Saskia Keuzenkamp

Introduction

Labour participation and unemployment of men and women, both migrant and native

Differences in sectors of employment

Income, working conditions and terms of employment

Deskilling and underutilisation of skills and educational qualifications

Immigration, legal status and employment 
$4 \quad$ Employment equity policies in work organisations

Stijn Verbeek and Rinus Penninx

Introduction $\quad 69$

Different concepts and perspectives $\quad 70$

Classifications of employment equity policies $\quad 71$

Existence of employment equity policies and their evaluation $\quad 78$

$\begin{array}{ll}\text { Conclusions } & 87\end{array}$

5 Diversity management and the business case 95

Michael Fischer

Introduction $\quad 95$

What is diversity management? $\quad 96$

The benefits of diversity management $\quad 99$

The implementation of diversity management 101

The business case: the diversity-performance link 103

Contextualising the impact of diversity 108

The business case for diversity management 112

$\begin{array}{ll}\text { List of contributors } & 119\end{array}$ 


\section{Preface}

Knowledge on processes of international migration and integration is often highly fragmentised, while there is evidence that such knowledge can contribute to migration and integration policymaking. For these reasons, 23 European institutes joined forces and established a Network of Excellence on International Migration, Integration and Social Cohesion (IMISCOE) in the Sixth Framework Programme of the European Commission. IMISCOE brings together knowledge and expertise that covers a wide range of topics. These topics involve research into both European and worldwide developments that influence migration flows and integration processes, and are often the subject of political and public debate. IMISCOE aims to share this knowledge and expertise with policymakers and other stakeholders in the field. It endeavours to reach these target groups and to make scientific knowledge available to them. After all, scientists and policymakers work in different sectors and face varying responsibilities and time constraints.

In the context of the IMISCOE Network of Excellence, we initiated a special kind of collaboration between science and policymaking on the theme of equal opportunities and ethnic inequality in European labour markets. IMISCOE researchers drafted four reports on specific subthemes within this thematic field: I) ethnic discrimination and equal opportunities; 2) gender and access to the labour market; 3 ) equity policies within work organisations; and 4) diversity management. These reports were first discussed in a preparatory session and then presented at an international meeting including representatives of trade unions, international companies and employers' organisations. Our aim was to share knowledge on the specific topics and identify information gaps and effective measures to achieve equal opportunities.

This publication is a compilation of the four aforementioned reports and has been made possible by financial support from the Dutch Ministry of Housing, Spatial Planning and the Environment (VROM, Directie Integratie en Inburgering). We would also like to thank the National Network of Diversity Management (DIV) for identifying key partners for the workshops that led to this publication. Finally, we would like to thank Andrew Maggiore for carefully editing the manuscript and helping bring this publication to its realisation. 
The results of the discussions that took place at the workshops and an abstract of the working papers are also available on the IMISCOE website (www.imiscoe.org). See IMISCOE Policy Brief No. 6, 'Diversity, Equality and Discrimination in Working Life' (Kraal \& Roosblad 2008a) and IMISCOE Working Paper No. 22, 'Equal opportunities in the labour market for immigrant people and ethnic minorities' (Kraal \& Roosblad 2008b). 


\title{
1 The ideal of equal opportunities and the practice of unequal chances
}

\author{
Karen Kraal, John Wrench, ${ }^{\mathrm{I}}$ Judith Roosblad and \\ Patrick Simon
}

\section{Introduction}

In November 2007, the IMISCOE Network of Excellence organised an international policy workshop entitled 'Equal Opportunities in European Labour Markets', in which researchers and representatives of trade unions, international companies and employers' organisations came together to discuss opportunities on the labour market for immigrants and ethnic minorities. ${ }^{2}$ In preparation for this international workshop, IMISCOE researchers prepared working papers with specific focus on: I) discrimination; 2) gender; 3) equity policies; and 4) diversity management. ${ }^{3}$

The organisers and participants concurred that there is a continuous need to analyse labour market mechanisms in post-industrial Western societies. This is because immigrants and ethnic minorities still experience unequal and limited access to these labour markets, despite the increasing number of laws and policy measures developed at the European, national and local levels to tackle discrimination. ${ }^{4}$ They deemed it crucial to create a dialogue between different parties that have valuable knowledge and experience related to this field, but they also wanted to develop expertise from both the scientific and practical angles. Together, the participants aimed to transfer knowledge from social science and economics to a more operational perspective and, conversely, to consider the experiences and logic of human resource managers or trade unionists as legitimate scientific data that can lead to a better understanding of discrimination.

The four workshop papers and the discussions that took place at the international workshop form the basis of this publication. ${ }^{5}$ Before presenting the focus and organisation of this book, we will first outline the relevance of the overall theme and the specific subthemes and explain how these are interlinked. 


\section{Democratic states' idealism versus reality}

Democratic states typically promote equal opportunities in society as a desired outcome of governance and as essential for stability, social cohesion and prosperity. Ideally, all residents of a country should have equal opportunities to participate in the various realms of society, such as politics, education, healthcare, culture and the labour market, regardless of their age, gender, religion or ethnic background.

Equal opportunities in the labour market are important for various reasons and contribute to social cohesion and prosperity in a number of ways. It is the labour market where people earn their living and where their quality of life and that of their offspring are determined. In many cases, wage earning is a condition for being fully part of a welfare state's social security system, including the right to health insurance and a pension. Society benefits from an optimal use of people's capacities and their limited dependence on government aid. Chronic unemployment or being forced to work below one's qualification level can lead to an underutilisation of worker potential, and therefore to the loss of this human capital.

Labour markets are organised around the concept of competition, which means that there are processes of selection. People are selected on the basis of skills that are in line with the requirements of the specific job, such as educational background and language proficiency. In 'fair' selection processes, equal opportunities in the labour market express themselves according to criteria that are relevant to a rational market.

Unfortunately, many people still have limited or no access to the labour market. Immigrants and ethnic minorities suffer unevenly from unequal chances in the labour market. Since the I970s, most European countries have consistently demonstrated significantly higher rates of unemployment for immigrants and ethnic minorities who originate from outside Europe. Research also shows that the majority of immigrant workers are overrepresented in jobs with poor career prospects and regularly experience problems once they have a job. These can include lower wages, unfavourable terms of employment, less access to opportunities for promotion, training or higher pay and verbal or physical harassment (Jonsson \& Wallette 200I; Zorlu 200I).

It has long been assumed that the problem of labour market exclusion was one that affected primarily 'first-generation' immigrants, but young ethnic minorities, even when they are born and educated in EU member states, still do not experience equal employment opportunities. Despite the fact that these young people may have access to social mobility and get better positions than those of their parents, research reveals that in most democratic states, the majority of immi- 
grants and ethnic minorities still experience fewer and less favourable opportunities in the labour market.

In addition to social arguments for equal opportunities in the labour market, equal opportunities are also important from a business point of view in that they maximise the available resources in the labour market. Not acknowledging the potentials of certain groups of workers can drive up the price of labour in times of labour shortages, and especially in times of economic growth (Brekel van den et al. 1999). Furthermore, a heterogeneous workforce could help an enterprise to relate to a wide range of clientele and create business opportunities through the employment of people who have insights into new customer markets (Lewis \& Lewis I996).

\section{Multiple disadvantages: the role of gender}

Not only do migrant and ethnic minority workers have fewer opportunities in the labour market than their indigenous counterparts, but research has shown that the cumulative effects of gender and ethnic inequalities lead to a gender stratification in which native men have the best labour market opportunities and migrant and minority women are the most disadvantaged in many EU member states. Their employment is heavily concentrated in particular segments of the market characterised by low pay, low status and insecure jobs (EU Monitoring Centre on Racism and Xenophobia 2003). Nonetheless, migrant women are not a homogeneous group and differ by demographic characteristics, nationality, education, skills, religion, mode of entry (labour, family, asylum, student), duration of residence, labour force participation and employment.

\section{Explaining unequal opportunities}

There are many reasons for the exclusion of immigrants and ethnic minorities from the labour market and their overrepresentation in precarious and 'atypical' work. There has been a tradition of media and politicians emphasising what might be called 'supply-side' factors in explaining why post-war labour migrants and their descendants in Western European countries have long been overrepresented in long-term unemployment or in poorly paid, insecure and generally undesirable work. Immigrants are seen as having a weak command of the local language, a poor educational history, and fewer qualifications than their indigenous counterparts. Therefore, 'integration policies' try to reduce these supply-side disadvantages by encouraging immigrants to take language courses, improve their education and attend vocational train- 
ing courses, as well as courses in the host country's culture and institutions.

In recent years, however, there has been an increasingly vocalised concern throughout the EU that this emphasis is flawed. Certainly an education and training approach can be necessary for newly-arrived immigrants and refugees or in cases where economic restructuring and organisational changes have put new demands on longer-established immigrant workers, but this tactic is often irrelevant for many longsettled migrants and their children. The problems faced by these groups are less easily explained by supply-side arguments. Even with language fluency and comparable education, members of minority ethnic groups are shown to suffer labour market exclusion and marginalisation when compared to their autochthonous peers. Here, demandside factors are more important in constraining the employment opportunities of ethnic minorities in Europe, regardless of how well qualified these individuals might be. One of these demand-side factors is 'racial' or ethnic discrimination.

\section{The role of discrimination}

Even when educational background, length of stay and language skills are not the problem, high unemployment and poor employment conditions for immigrants and ethnic minorities continue to exist. Therefore, researchers generally conclude that a significant degree of unequal opportunities in the labour market is the result of discrimination (Knocke \& Hertzberg 2003; Helgesson 2000; Höglund 2002). Discrimination can be defined as treating people differently on the basis of their gender, race, religion, ethnicity or their membership (perceived or otherwise) in a given social group. The form of discrimination that is known as 'ethnic discrimination' takes place when the criterion for negative treatment is based on one's supposed belonging to an ethnic category or group. In the case of migrant women, race and ethnicity as central dimensions of inequalities in the labour market intersect with the dimension of gender.

Although discrimination can be used to explain a lot of labour market exclusion, it is a very loaded term. Most employers do not wish to be accused of being discriminatory and those who are being discriminated against may also be reluctant to explain their situation in terms of discrimination. Often, people prefer just to speak about diversity when discussing ethnic labour market participation. The dissemination of the concept of diversity is strongly connected to the development of management tools in human resource networks, especially in the framework of the European strategy against discrimination (Kalev, Dobbin \& Kelly 2006; EC 2005). While changes of terminology may assist in 
making debate more comfortable, real change in practice is about better understanding the explicit forms and causes of discrimination and possible measures to combat it.

\section{How can societies combat discrimination and create equal opportunities?}

Equal opportunities for all, whether in the labour market or in society at large, have been on the agenda of the European Union for several decades. In 2000, the European Union enacted two directives that prevent its residents from being discriminated against on the grounds of race and ethnic origin (the Racial Equality Directive) and on the grounds of religion, disability, age or sexual orientation (the Employment Framework Directive). The two directives define a set of principles and guidelines to guarantee people in the EU a common minimum level of legal protection against discrimination. At the national level, individual countries have also enacted laws and formulated policies to improve employment equity within their own borders. But social partners, both at the EU and national level, are also seen as playing an important role in bringing about equal opportunities in the labour market. After all, it is the workplace where people actually enter the labour market and opportunities can be created. At the same time, however, there are competing views on the desirability, selection and possible effects of specific equity policies and measures, and it is not completely clear how successful antidiscrimination policies actually are.

In recent years, the EU has increasingly turned its attention to issues surrounding migrant women's participation in the labour market and the challenges they face. The European Commission has acknowledged that getting a better understanding of migrant women in the labour market is a key condition to developing appropriate policy responses to the problems these women are confronting.

\section{Diversity management and the business case}

Managing for diversity is a management strategy that intends to make productive use of differences between individuals, ethnic and otherwise. It is based on the premise that diverse, well-managed teams will produce better results and that diverse companies will gain a market advantage. In contrast to other employment equity policies, diversity management is primarily driven by the 'business case', or the argument that diversity and/or the managing of it will increase organisational efficiency and profitability. As diversity management gains popularity as a business practice in Europe, the question of whether it deli- 
vers the benefits its advocates promise becomes increasingly relevant in particular to those involved in the discussion and implementation of employment policies relating to ethnic and other minorities. An examination of the literature, however, shows that there is no consensus regarding the business benefits of diversity and the management of it.

\section{The focus and organisation of this book}

In this volume, we aim to describe the current labour market position and opportunities of immigrants and ethnic minorities, to analyse the factors that negatively influence this position and these opportunities (specifically those of migrant and ethnic minority women), as well as to ultimately analyse antidiscrimination measures and policies (specifically within companies and businesses) and their effects. The main purpose of this volume is not to build new knowledge, but to introduce up-to-date research findings and challenge some established assumptions regarding discrimination and equity policies.

The four described subthemes will be dealt with in four separate chapters. Chapters 2 and 3 focus primarily on examining the labour market position of immigrants and ethnic minorities, both men and women, and in doing so these chapters draw heavily on statistical data. Chapters 4 and 5 address different types of equity policies and evaluate their effects, thereby relying more on previous research that has employed survey data to evaluate such policies.

For all the chapters, however, we have chosen to address the topics from a comparative European perspective. Not only does research show that the labour market position of immigrants is worrisome throughout Europe, but comparison between different national settings will help us understand the various mechanisms that influence this labour market position and provide insight into the effects of related policies. For example, various research methods presented in Chapter 2 that have been used in different European countries show that ethnic discrimination plays an important role in limiting the chances of immigrants and ethnic minorities in Western labour markets. Therefore, our aim has been to consider and compare research data from various European countries in our workshop papers, and to bring together representatives from various European countries in the workshop that underlies this volume.

That said, using and comparing cross-national data is not without its difficulties. Countries typically use different registration methods (such as for the first and second generation), but labour market structures, provisions and related policies differ as well. Each chapter takes such 
difficulties into account and explains how it deals with possible incomparability or even lack of data.

In Chapter 2, Angela Nilsson and John Wrench discuss the role of ethnic discrimination in working life and present evidence of such discrimination. Through the presentation of various international comparative statistics and national case studies, they first show the labour market position of immigrants and ethnic minorities in various EU member states. This position is characterised by high unemployment rates and poor work conditions. The authors argue that this situation cannot be explained exclusively by the minorities' skill level and their specific migration history. Court cases, surveys and field experiments in various countries show that ethnic discrimination plays an important role in limiting the chances of immigrants and ethnic minorities in Western labour markets. The chapter concludes with reference to a typology of different forms of discrimination that provides insight into the specific processes that underlie both direct and indirect discrimination.

In Chapter 3, Eleonore Kofman, Judith Roosblad and Saskia Keuzenkamp discuss the position of migrant and minority women in the labour market in relation to that of migrant men and native women. They present innovative empirical results concerning labour market participation of both migrant men and women, and widen their empirical approach by taking a closer look at specific sectors in the labour market where migrant and minority women are typically employed or excluded. The authors discuss various factors that are of influence on the labour market position of migrant women, including skills, migration history, legal status and educational background. In their conclusion, they argue that such factors alone cannot explain the poor and vulnerable labour market position of especially migrant women, and that ethnic discrimination also plays a crucial role. Ethnicity and gender as central dimensions of inequality seem to interact and lead to multiple disadvantages.

In Chapter 4, Stijn Verbeek and Rinus Penninx look at processes of ethnic discrimination and unequal positions in the labour market from a policy perspective. For this purpose, they analyse up-to-date literature on employment equity policies (EEPs) written by some key authors in the field. The workshops that led to this volume revealed that trade unions, employers' associations and large companies are stakeholders that should be informed about the state of research in this field. As a result, Verbeek and Penninx focus in on EEPs within organisations. The authors introduce some crucial aspects of EEPs and describe the various instruments that make up such programmes, outlining their scope in the process. 
In Chapter 5, Michael Fischer analyses the increasingly popular business practice of diversity management as a form of equity policy and reflects critically on the main assumptions underpinning this approach. He illustrates the characteristic features of diversity management and its benefits as described by its proponents, and gives an overview of the way in which diversity management is implemented. The author then looks at the business case for diversity. This includes a discussion of the effects of diversity upon performance and of the intervening variables that influence this impact. Finally, he examines the relevance of this debate about the supposed positive relation between diversity and staff performance for the business case of diversity management. The author argues that this relevance is limited, as the business case for diversity management and the business case for diversity are two interconnected, but different issues.

\section{The role for future research}

Scientific research can play an important role in the field of equal opportunities. Through scientific research, we are able to analyse and evaluate policies that aim to achieve equal opportunities and combat discrimination. It can provide data that monitors the labour market position of migrants and minorities and the occurrence of ethnic discrimination, but it can also enhance our understanding of certain concepts that apply to this field. Some of these concepts are often used in scientific, political and public debate, but their exact meaning is not always clearly explained and sometimes even confused. Examples include diversity and equality, equal treatment and equal results, diversity and diversity management and the social justice case versus the business case. Nevertheless, the choice to use certain concepts when discussing labour market participation also involves a choice for certain policies and measures relating to these concepts.

The term 'diversity' is becoming dominant when discussing equal opportunities, particularly in public and political debate. This relates to the aforementioned unpleasantness that the term 'discrimination' can connote. Diversity implies positivity and something challenging, while discrimination is shrouded in negativity. Nonetheless, diversity is not the same as equality. A diverse staff does not necessarily mean that ethnic discrimination is nonexistent and that opportunities are the same for all people involved. Companies can even specifically aim to hire workers from ethnic minority groups because they are only too willing to recruit exploitable workers in this category. ${ }^{6}$ Equality, however, entails opportunities and chances uninfluenced by ethnic discrimination. To achieve equal chances in the labour market, antidiscrimination, 
equality and diversity should be combined. Equal chances are not brought about by a diverse staff alone, but require equal work conditions and career prospects as well.

The terms 'equal treatment' and 'equal results' are also used interchangeably on a regular basis, but both involve different policies and measures. Employment equity can be explained as the equal treatment of all people, regardless of background, that allows them equal opportunities to access the labour market and move to other jobs. But employment equity should also account for equal results - ensuring that people with comparable education and work experience not only have equal access to work, but also perform at comparable levels and earn comparable incomes. If our goal is to achieve the equal treatment of all people, our policies must also accommodate measures focused specifically on ensuring these equal results. The success of a policy aimed at granting equal employment access will be defined differently than that of a policy promoting the equal treatment of people already enjoying work. As we will show later, the latter approach is more controversial, as it could lead to the enforcement of hard affirmative action, forcing companies and organisations to implement such policies - whatever form they may take - and, notably, to combat institutional discrimination in a proactive way. Aiming at equal treatment alone, however, will leave many forms of discrimination untouched.

The business case for diversity and the business case for diversity management are two interconnected but different issues. While the business case for diversity aims to increase the diversity of employees because this will improve business performance, the business case for diversity management means managing a diverse staff well, utilising the positive elements that come along with the diversity and increasing business success. As we will show, research has no clear answers regarding the first concept - namely, that a diverse workforce will automatically lead to business benefits. Such research indicates that the good management of diversity is a way to avoid potentially negative effects while promoting potentially positive ones.

Finally, we should be clear on our assumptions when discussing labour market opportunities. In our terminology, we refer to the social justice case versus the business case: in other words, you have to versus you will benefit from. Is our goal to analyse how labour market mechanisms influence labour market participation and performance because we assume that all people deserve equal chances, no matter how much it costs, or because we assume that this will profit business? Typically speaking, the former is the basis of scientific discussions, while the latter might be more likely to interest stakeholders like businesses and companies. 
Awareness of the interconnected yet very different character of the abovementioned pairs can strengthen further research in this field. By disentangling such concepts and unveiling the normative values that influence their application, scientific research can contribute to a better understanding of the labour market position of immigrants and ethnic minorities, as well as aiding in the evaluation of related equity policies.

\section{Detecting and monitoring labour market participation}

In this context, statistics are an important set of hard data. Through the use of statistics, we can inspect apparently neutral procedures and practices, identify their possible discriminatory consequences and promote equality actively (Goldston 200I). Applying statistics in this manner has always been considered controversial. Reference to race or ethnicity in labour market registrations was a suspect practice in itself, since racial characteristics are considered deceptive, unknown to the victims of racism and often to the persons responsible for selection as well. The monitoring of apparently neutral procedures can reveal their discriminatory effects on specific (and often vulnerable) groups. In short, statistical data makes it possible to bring disguised forms of discrimination out into the open.

Measuring discrimination goes beyond the mere counting of discriminatory acts or quantitative assessment of unfavourable treatment. It includes a range of statistical applications in equal treatment strategies, such as statistics to reveal the existence of systemic or indirect discrimination. Social science research and analysis of discrimination cases form a body of knowledge that reveals the structural nature of discrimination, as confirmed by the persistence of differences in treatment and results recorded by surveys or by exploitation of census data. But it is also necessary to increase public awareness of the general character of discrimination and to outline options for policymakers. Statistical proof provides particularly eloquent arguments that underline victims' testimony and give it credibility.

As we will show, current research is not able to offer a representative picture of the existence and effectiveness of equity policies in different countries, and the range of possible unintended consequences, is not adequately documented yet. Current knowledge seems to be relatively impressionistic, this because it is difficult to evaluate the effects of instruments and programmes with so many contextual factors at play. Furthermore, there is no systematic monitoring and analysis of the benefits of a diverse workforce, nor is there a cost-benefit analysis of the policies aimed at increasing diversity. Moreover, many studies seem to focus on the effects of diversity on the individual and group levels, while the effects on the organisational level and upon actual organisa- 
tions are also of crucial importance. It can also be problematic that many studies on the effects of diversity have measured performance in laboratory settings, which do not include all the contextual factors of actual organisations, and that research in real organisations is comparably underdeveloped. Employment equity policies should therefore remain high on the research agenda. Which sorts of programmes will enhance group processes and efficiency, and which might be potentially useless, or even counterproductive? Again, statistics could play a crucial role as an inspection tool that checks the procedures applied by bodies that have implemented equity policies. Statistical monitoring subjects systems to continuous in-depth inspection, making it possible to identify suspected discrimination and unequal treatment and results. It can also help to set and revise objectives to measure the progress of equality programmes.

Equal opportunities in the labour market will not be maintained or achieved without the commitment of all stakeholders, including employers, trade unions, public authorities and the employees themselves. But good intentions are not sufficient per se: tools and methods are required, as well as knowledge about the consequences of the different processes involved in working life. Awareness through monitoring and data collection is a crucial parameter to secure equal opportunities in European societies.

\section{Notes}

I The views expressed in this chapter are those of John Wrench and his co-authors, and not those of the EU Agency for Fundamental Rights.

2 The following organisations were represented at this international workshop (in alphabetical order): ABN AMRO, the Netherlands; ArbeitKammer (AK) Vienna; Centre for Research in International Migration and Ethnic Relations (CEIFO), University of Stockholm; Confederation of Swedish Enterprise; City district Geuzenveld, Amsterdam; DIV/National Network Diversity Management, the Netherlands; ERCOMER/Erasmus University of Rotterdam; European Union Agency for Fundamental Rights (FRA), Vienna; FNV (Dutch Trade Union Federation); Foreningen Nydansker, Denmark; Vrije Universiteit Amsterdam (VU); ICTU (Irish Congress of Trade Unions); Independent High Commission for Equality and against Discrimination (HALDE), France; International Trade Union Confederation, Brussels; National Farmers' Union, United Kingdom; NSZZ Solidarność (Independent and Self-Governing Trade Union), Poland; Rabobank, the Netherlands; Social and Cultural Planning Office, the Netherlands; SZW (Dutch Ministry of Social Affairs and Employment); Migration Research Group, Hamburg Institute of International Economics (HWWI); The Swedish Confederation of Professional Employees (TCO); Unite/Transport and General Workers Union (T\&G), United Kingdom; VNO-NCW (Confederation of Netherlands Industry and Employers); VROM (Dutch Ministry of Housing, Spatial Planning and the Environment).

3 The respective authors of these four state-of-the-art reports were: a) Angela Nilsson (CEIFO, University of Stockholm); b) Eleonore Kofman (Social Policy Research Cen- 
tre, Middlesex University) with Bernadetta Siara (Westminster University), Floya Anthias and Maja Cederberg (FEMIPOL Project, Oxford Brookes University); c) Stijn Verbeek (Erasmus University Rotterdam); and d) Michael Fischer (Migration Research Group, Hamburg Institute of International Economics (HWWI). A compilation of these reports was first discussed in an expert meeting with representatives of Dutch trade unions and employers' associations, co-organised with the Dutch National Network Diversity Management (DIV). A revised paper functioned as the main discussion paper during the international workshop in November 2007.

4 Here, the term 'ethnic minority' is used to mean a relatively recent population, namely the post-World War II immigrants from outside Europe and their descendants, who often, but not always, have citizenship rights in an EU member state.

5 Both these reports and the results of the discussion are also published as IMISCOE Working Paper No. 22 and IMISCOE Policy Brief No. 6 (see www.imiscoe.org/ publications).

6 As we will see in Chapter 2, this is called 'opportunistic discrimination': this is differential treatment, and possible exploitation, based not necessarily on the racism or prejudice of the employer, but on the knowledge that the minority ethnic group is in a weak position in society and in the labour market.

\section{References}

Brekel, C. van den, M. van Klaveren \& K. Tijdens (1999), The Absence of Women in the ICT-sector.

EC, DG ESAEQ (2005), The business case for diversity. Good practices in the workplace. www.ec.europa.eu/employment_social/fundamental_rights/pdf/pubst/stud/ busicase_en.pdf

EU Monitoring Centre on Racism and Xenophobia (2003), Migrants, Minorities, and employment: Exclusion, Discrimination and antidiscrimination in 15 member states of the European Union. Vienna: EUMC.

Goldston, J., (200I). 'Race and ethnic data: a missing resource in the fight against discrimination', in A. Krizsàn (ed.), Ethnic Monitoring and Data Protection: the European Context, I9-4I. Budapest: CEU-INDOK.

Helgesson, Linda (2000), 'Högutbildad men diskvalificerad - Några invandrares roster om den svenska arbetsmarknaden och vägen dit', Gerum Kulturgeografi 2000: 2. Umeå: Umeå Universitet.

Höglund, S. (2002), 'Invandrarna och arbetsmarknaden', in Arbetslivet, L. H. Hansen \& P. Orban (eds.), 40I-435. Lund: Studentlitteratur: Lund.

Jonsson, A. and M. Wallette (200I), "Är utländska medborgare segmenterade mot atypiska arbeten?', in Arbetsmarknad and Arbetsliv, nr. 3 2/200I. Stockholm: Arbetslivsinstitutet.

Kalev, A., F. Dobbin and E. Kelly (2006), 'Best practices or best guesses? Assessing the efficacy of corporate affirmative action and diversity policies'. American Sociological Review 7I (4): 589-6r7.

Knocke, W. \& F. Hertzberg (2003), Retorik och praktik i rekryteringsprocessen. Stockholm: Arbetslivsinsitutet.

Kraal, K. \& J. Roosblad (2008a), 'Diversity, Equality and Discrimination in Working Life', IMISCOE Working Paper No. 6, Amsterdam: IMISCOE.

Kraal, K. \& J. Roosblad (2008b), 'Equal opportunities in the labour market for immigrant people and ethnic minorities', IMISCOE Working Paper No. 22, Amsterdam: IMISCOE.

Lewis, S. and J. Lewis (1996). The work-family challenge. London: Sage Publications. 
O'Grady, A., N. Balmer, B. Carter, P. Pleasance, A. Buck and H. Genn (2005), 'Institutional Racism and Civil Justice', Ethnic and Racial Studies 28 (4): 620-638.

Zorlu, A. (200I), Do ethnicity and sex matter in pay and employment choices? Analysis of 8 groups in the Dutch labour market. Amsterdam: University of Amsterdam Press. 



\title{
2 Ethnic inequality and discrimination in the labour market
}

\author{
Angela Nilsson and John Wrench
}

\section{Introduction}

Unequal opportunities in work life are perceived as serious problems, not only because they have an impact on the income and social status of those who are excluded or subordinated in the labour market, but also because they undermine the social political system, lead to the waste of human resources and to the underutilisation of skills, knowledge and manpower, and prevent access to the advantages that different types of knowledge can bring in a globalised economy (Fridholm 2006; EC 2005).

As stated in Chapter I, it is common wisdom that not everybody has equal possibilities in working life. Disparities in skills, talents, merits, ambitions, experiences, so to say human capital, but also networks, 'habitus', social and family background, so to say social capital, shape a person's position in economic life. But these structural parameters are mediated, or jeopardised, by gender and race/ethnicity. In this chapter, we focus on the influence of ethnic discrimination on access to the labour market. Racial and ethnic discrimination is a multifaceted concept that can be understood and used in different ways. In this report, the concept means different, unfair and negative treatment of people because of the colour of their skin or their ethnic background, instead of taking into account criteria such as skills, aptitudes and qualifications. In working life, this implies, for instance, that persons with an immigrant background are valued less than they deserve.

To be able to combat discrimination, we need an overview of the problem and its occurrence, as well as an understanding of the different mechanisms that generate discrimination. The aim of this chapter is to provide a synthetic overview of the main issues related to ethnic and racial discrimination in working life. By doing this, we aim to highlight the necessary changes that have to be made in order to establish a fairer and more equitable working life. 
The chapter is structured in the following way:

- Firstly, the chapter presents comparative European statistical data and research findings that demonstrate the unequal circumstances of immigrants and ethnic minorities in the labour market in different Western societies. This data covers differences in rates of employment and in employment conditions.

- This is followed by the presentation of indirect and direct evidence on the part that ethnic discrimination plays in this labour market inequality. This consists of (I) statistical evidence, presenting indirect evidence of discrimination; (2) direct examples of discrimination from cases dealt with by courts and tribunals; and (3) direct evidence of discrimination from research, in particular surveys and 'discrimination testing' field experiments.

- Finally, the chapter shows how the identification and categorisation of the various types of discrimination can help to provide better insight into the various underlying dynamics of, and possible solutions to, the problem.

\section{Comparative data on employment rates}

When analysing the labour market position of immigrants and ethnic minorities, a first step to take is to look into international comparative statistical data on employment rates: how well do immigrants and ethnic minorities gain access to the labour market in the various EU member states?

Figure I sets out a comparison of the employment rates of the native-born and foreign-born population in sixteen European countries, plus the US and Canada. The figure shows that in the majority of countries, the rate of employment is lower for the foreign-born than for the native-born. One of the largest differences between unemployment levels is found in Denmark, where 6 per cent of the native Danish were unemployed in 2003 , compared to 25 per cent of citizens with a background from a non-European country (Muus 2002).

The unemployment rate of citizens in comparison with that of noncitizens is another piece of statistical data that can be useful in gaining insight into the labour market position of immigrants and ethnic minorities. While most EU member states do not record ethnic or national origin in their official statistics, almost two-thirds of them do provide statistics from which the rates of unemployment of 'citizens of countries from outside the EU' can be compared to those of 'citizens of member states'. In 2007, a comparison was made in sixteen EU member states between the unemployment rate of non-citizens from outside 
the EU-25 and that of EU citizens for the second quarter of 2006 (FRA 2007: 44-45).

Figure 2.1 International comparison of the employed part of the population: differences between native-born and foreign-born, aged 15-64, 2003

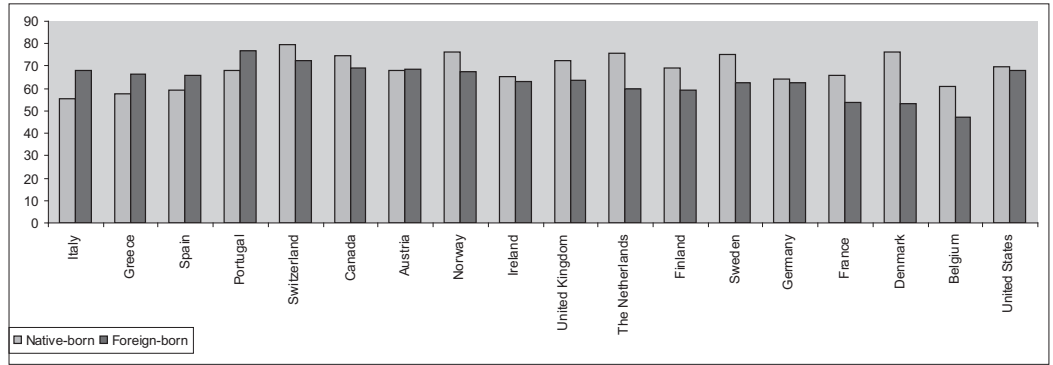

Source: Integrationsverket 2006, refer to OECD 2005

Figure 2.2 'The ratio of the unemployment rate of non-citizens from outside the EU-25 to that of EU citizens in sixteen member states, second quarter of 2006

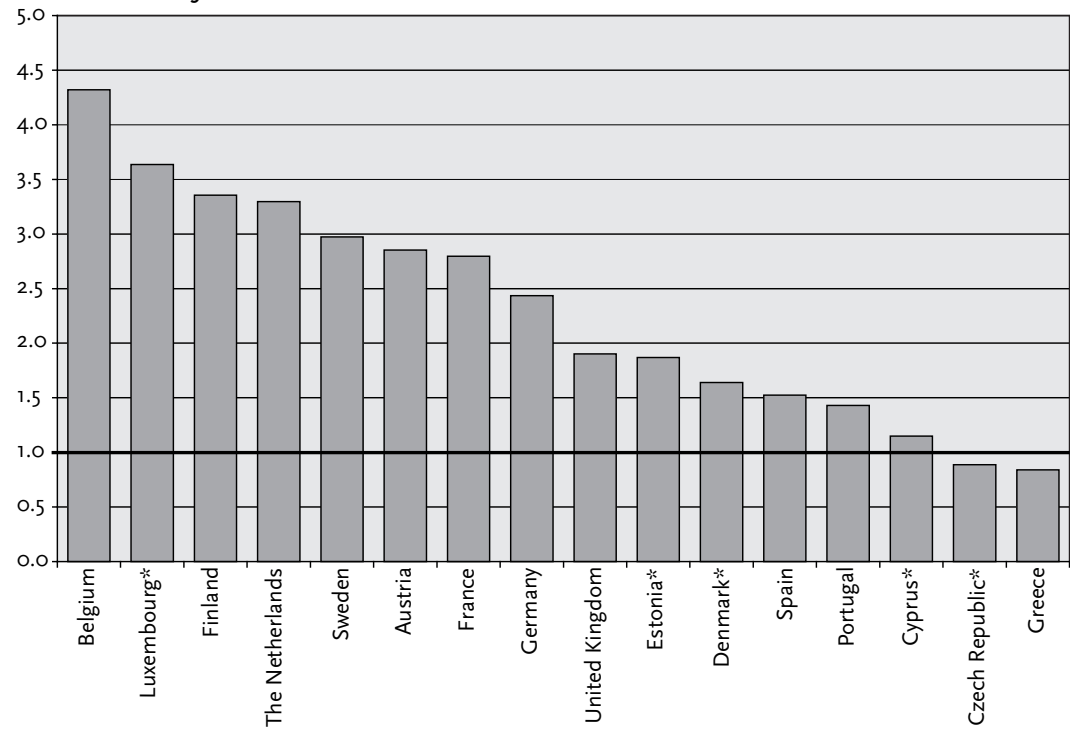

*Data on the unemployment rate of non-citizens from outside the EU-25 may be unreliable or uncertain for these countries.

Level ' 1.0 ' on the vertical axis denotes the level of unemployment of citizens of the member state.

Source: EUROSTAT - Figure from 'Report on Racism and Xenophobia in the Member States of the EU', FRA 2007 
Figure 2 shows that non-citizens from outside the EU are in most cases significantly more likely to be unemployed than citizens.

The employment rates of immigrants are furthermore highly sensitive to economic fluctuations. The patterns are the same in most Western European countries (OECD 200I). When there are plenty of jobs, immigrants are included in the labour market, but during times of recession, they are among the first to be excluded and they have the least chance of finding new employment (Integrationsverket 2006). In 2008, the United Kingdom Equalities and Human Rights Commission forecast a 'mass exodus' of one million migrant workers from Great Britain alone who will be sent home due to the global financial crisis. ${ }^{2}$ Similarly, the Secretary-General of the UN, Ban Ki-moon and the International Labour Organization warned that the crisis would lead to millions of migrant workers in Europe losing their jobs. ${ }^{3}$

\section{Limitations of international comparative statistics}

While the above figures on unemployment rates seem to provide an initial basis for comparison of labour market integration between member states, this comparison is only of limited value. The statistics are affected by distorting factors related to the characteristics, policies and registration methods of the different member states, such as the varying requirements for obtaining national citizenship. For example, in a member state where citizenship is relatively easy to obtain, the unemployed 'non-citizens' group will contain proportionately more recent arrivals, while in a country where it takes much longer to acquire citizenship, the 'non-citizens' group will contain more longer-term residents, but this does not necessarily reflect a worse labour market position. ${ }^{4}$

Another problematic aspect of international statistics is that the immigrant population is usually described as one category, which thereby hides the heterogeneity of a group that ranges from labour immigrants to refugees, from atomic physicists to illiterates and from individuals who migrated during the 1960 s to those who migrate in the $21^{\text {st }}$ century. These differences are potentially relevant to labour market success and can be crucial for the immigrants' position in the labour market (Integrationsverket 2006).

Furthermore, the specific migration history of the country in question can influence the labour market position of immigrants who are part of this history. Former colonial powers have experienced extensive immigration flows from their former colonies. Many of these immigrants are familiar with the new country's language, and even speak it as their native language. Quite a large part of those who migrated to Belgium and France came from former colonies and countries where French was spoken, and almost 86 per cent of the foreign citizens in 
Great Britain came from a country were English is spoken (Integrationsverket 2006; EUMC 2006). For some migration flows, geographical closeness plays a role, such as in the case of the Finns who migrated to Sweden, while linguistic closeness is more important for others, such as the many migrants who chose the US, Canada, Australia, New Zealand, Great Britain or Ireland as their destination (OECD 2003; Integrationsverket 2006). Some of them speak the new country's language as their mother tongue, while others hear that language for the first time the day of their arrival. Proficiency of language and familiarity with cultural values can enhance one's chances on the labour market.

This discussion about the shortcomings of statistics is even more complex when we consider the labour market position of the second generation, and more generally the members of ethnic and racial minorities. Data describing these groups is generally not collected in European countries, and the definition of these populations varies across member states depending on the history of immigration, colonisation, slavery and the existence of national minorities. ${ }^{5}$ As a consequence, the assessment of the labour market position of the second generation and ethnic minorities relies on fuzzy classifications and cannot be consistently compared between countries. ${ }^{6}$

In sum, these types of statistics have their limitations in international comparison. Because of these limitations, it is more meaningful to focus on studies within individual countries in order to gain better insight into the patterns of employment inequality.

\section{National studies on unemployment rates of immigrants}

Some individual member states have unemployment statistics that can be broken down by ethnic or national group, and these can show striking differences between groups within one country. In Belgium, the highest unemployment rates among all groups are those for Turkish and Moroccan nationals (45 per cent for males, 56 per cent for females) compared to the unemployment rates for Belgian nationals of Io per cent (Algemene Directie Werkgelegenheid en Arbeidsmarkt 2006). North Africans in the Netherlands, Belgium, France and Portugal, especially the young people among them, are faced with an unemployment rate far higher than that of the native majority population (Meurs et al. 2006; Silberman et al. 2007; EUMC 2002a, b, c). In the Netherlands, of all the non-Western immigrant groups, Moroccans top the list with an unemployment rate of 20 per cent (Van den Maagdenburg 2004). For 'new' immigrant groups, most of whom are from refugee backgrounds, unemployment figures are considerably higher than 
for the 'traditional' immigrant groups (Klaver \& Odé 2005; Veenman \& Van Ours 2002).

Some of the highest rates of unemployment in Europe can be found among Roma and Traveller groups. A 2005 Czech report showed that only 26 per cent of the economically-active Roma population had not experienced unemployment (Inter-ministerial Commission for Roma Community Affairs 2005), and statistics in Ireland showed unemployment among male Travellers measuring 73 per cent, compared to a national level of slightly more than 9 per cent (Central Statistics Office 2004).

Both national studies and, to a limited extent, international comparative statistics teach us that unemployment rates among the nonWestern immigrant population and ethnic minorities are much higher than among the native population in most EU member states. A next step in analysing the labour market position of immigrants and ethnic minorities is through research on the labour market conditions when they are employed.

\section{Data on inequality in working conditions}

Research confirms that not only does labour market participation differ between the native population and people with a migration background, but also the terms of employment differ (Meurs et al. 2006; Rooth \& Ekberg 2003; EUMC 2002d: 4). Often, immigrants are engaged in atypical work and have unfavourable contracts with regard to working hours, the length of contract and salary scale. Statistical studies from Sweden, Belgium, the Netherlands, the UK and France show that the share of manpower in short-term employment is higher among immigrants than the native population (Attström 2007, EUMC 2002a; Houtzager et al. 2002: I5; EUMC 2002c). In Sweden, among people born outside Europe and with a maximum time of residence of nine years in Sweden, 3I per cent of the female workforce and 27 per cent of the male workforce are employed on a short-term basis. In comparison, 9 per cent of the Swedish-born female workforce and I5 per cent of the Swedish-born male workforce are employed on the short term (Attström 2007). The disadvantages with insecure employment are, for instance, less access to occupational health services, to in-service training and to social rights such as vacations (Meurs et al. 2006; EUMC 2002a). Furthermore, temporary employment does not appear to be an effective entrance to long-term employment for immigrants; on the contrary, they risk getting stuck permanently in an unstable form of employment. There is no support for the idea that shortterm employment is preferred by those who are searching for work, 
and several studies show that most people in temporary employment wish to have long-term employment (Aronsson et al. 2000).

Not only do terms of employment differ between native and foreign born people, but wages for comparable work also differ. Studies from the Netherlands, France and the UK show that the average gross income for ethnic minority employees is lower than for native employees (Houtzager et al. 2002: 4I; Meurs et al. 2006; EUMC 2002c). The average pay for men born in Sweden is higher than for men born abroad (Le Grand \& Szulkin 1999). These differences between Swedish-born and immigrant men do not decrease over time. Immigrant men who have been living in Sweden for more than twenty years still have lower wages than Swedish men with similar levels of education and experience (ibid.).

Finally, opportunities in the labour market can be limited by being occupied below one's education level, as was shown in a study among academically trained people in Sweden. Foreign-born academics are more likely to have an occupation below their education level than native-born academics in Sweden. Sixty per cent of all foreign-born academics had a job matching their education and competence, while up to 80 per cent of the natives had such a job (Rooth \& Ekberg 2006). The study also revealed that those who initially accepted a low-level job tended to be 'locked in' to that kind of occupation in the long run. This indicates that even the initial occupation needs to be of high level to make an individual's occupational position successful on the long term. Consequently, the quantity as well as the quality of earlier employment has an influence on future positions for immigrants in the labour market.

\section{Evidence of discrimination}

So far, we have seen that both the level of employment and conditions of employment are significantly inferior for immigrants or their second generation when compared to workers from majority groups. We will now consider examples of research to explore the role that ethnic discrimination plays in this. The issue here is to demonstrate that unequal economic outcomes do not only derive from disparities in qualifications, social background or experience in the labour market. There are, for example, many statistics and empirical studies which prove the fact that foreigners are more often unemployed than people with a 'native' background, even if they make similar efforts and have equivalent qualifications (OECD 2005; Neergard 2006). We will consider both indirect and direct evidence of discrimination. 


\section{Indirect statistical evidence}

To illustrate the role of discrimination in more detail, we first focus on Sweden. In the case of Sweden, the employment level of those with origins from outside Europe was only 49 per cent, compared to natives with a corresponding level of 80 per cent. There are factors that partly explain these differences in degree of employment, such as the loss of or differences in human capital and the length of time spent in the country in question (Ekberg et al. 2004; Schröder \& Wilhelmsson 2000; Arai et al. 1999; Simon 2007: 653). There is, however, no empirical evidence that language skills, educational level, job seeking activities or possible cultural differences could entirely explain the differences in the labour market performance (Lappalainen 2005; Arai et al.I999). In a Swedish survey on the educational level of immigrants, it was found that the immigrants' average level differed only slightly from the native population. In addition, statistics on the second generation show that differences in labour market outcomes remain even after obtaining acceptable grades in Swedish and finishing a minimal level of upper secondary school education (Arai et al. I999). In another study, comparisons were made between youngsters who were adopted as children and grew up in middle/upper-class Swedish families and native white Swedish youngsters (Rooth 200I). The individuals who were adopted as children were divided into two groups: those who could be considered as physically resembling native Swedes and those who could be considered as differing in appearance (skin, eye and hair colour). After carrying out a statistical compensation for differences in educational level, civil status and age, an unexplained difference in labour market participation of almost 7 per cent remained for the adopted children with a 'foreign look'.

Similar results have been found in other countries. While lack of success in the labour market is often related to skill level and qualifications, analyses which have applied controls for other variables indicate that human capital characteristics cannot explain all the differences in success for different groups. For example, studies in France show that the children of immigrants from North or Sub-Saharan Africa, despite their educational capital and familiarity with French social norms, face a higher risk of unemployment than native French, while the situation for immigrants from Southern Europe does not differ significantly from native French people (Meurs et al. 2006: 657; Silberman \& Fournier 2006). In Belgium, a similar situation holds for immigrants from Turkey and Morocco (EUMC 2002a: 13). Evidence from the UK suggests that the second generation has closed the gap with their white British counterparts regarding occupationally-related qualifications but not with respect to employment, again with significant differences be- 
tween groups (EUMC 2002c). More recently, studies comparing access to employment of equally qualified minority and majority populations in Belgium (VDAB 2007), Germany (Burkert \& Seibert 2007), the Netherlands (Langenberg \& Lautenbach 2007) and the UK (Botcherby 2006) found that after correcting for other variables, such as skills, age, gender and educational attainment, there were still differences between majority and minorities in accessing jobs at various levels.

This data shows that across many countries in Europe, success in gaining employment is not simply a reflection of ability or skill. The persistence of inequalities even after such relevant variables have been controlled for in the statistics suggests that factors of direct and indirect discrimination are also part of the explanation. The fact that qualified people are not getting access to jobs in line with their qualifications provides indirect evidence of discrimination, which is inferred from otherwise inexplicable inequalities. How can we be more certain that discrimination plays a part in this inequality? For this we need to turn to direct sources of evidence, one of which is concrete complaints of discrimination in the area of employment that appear each year in courts and tribunals.

\section{Direct evidence of discrimination}

\section{Evidence from complaints and complaints bodies}

All EU member states have been obliged to complete transposition of two antidiscrimination directives mentioned in Chapter I (Directives $2000 / 43 / \mathrm{EC}$ and $2000 / 78 / \mathrm{EC}$ ) since 2003 , and all new member states since 2004 (EUMC 2005: I9-20). Specifically Article 13 of Directive $2000 / 43 / E C$ states that member states must designate 'a body or bodies for the promotion of equal treatment of all persons without discrimination on the grounds of racial or ethnic origin'. Such bodies should have competences that include the provision of independent assistance to victims of discrimination in pursuing their complaints.

Due to the enforcement of the antidiscrimination directives, most European countries now have special authorities against discrimination where victims can file their complaints if they have been subject to discrimination. In the Netherlands, for instance, complaints can be filed at authorities such as the Antidiscrimination Agencies (AGBs), the Equal Treatment Commission (CGB) and the Public Prosecutions Department. In a Dutch report, it was noted that complaints are most often about recruitment and selection processes (Houtzager et al. 2002: 37). In Sweden, the 'Ombudsman' (DO) takes care of complaints and supervises measures taken by employers to counteract ethnic discrimination in working life. These complaints and measures are often connected to recruitment (Sjögren 2004). 
An examination of the Annual Reports of the EU's Fundamental Rights Agency or the European Commission against Racism and Intolerance (ECRI) national reports by the Council of Europe show examples of the kinds of complaints and court cases that can be found across Europe year after year. Just a few will be mentioned to demonstrate the nature of such cases. For example:

- In Belgium in 2005, the Chief Executive Officer of a Flemish private company that constructs sectional gates stated that his company refused to recruit non-white employees for the installation and repair of its gates, on the grounds that his Belgian customers would prefer to have whites on the job. This was strongly condemned in the Belgian media and a discrimination complaint was filed with the Centre for Equal Opportunities and Opposition to Racism (CEOOR).

- In Italy in 2006, a black Italian girl filed a complaint for racial discrimination against the owner of a restaurant who refused to employ her, saying that her skin colour could 'disturb' some of his customers (Manfredi 2007).

- In Hungary in 2006, the National Railway Company was fined for discrimination after dismissing all Roma employees while renewing the contracts of non-Roma employees who were less qualified (NEKI 2007).

- In France in 2006, a young black woman with French citizenship and a diploma in hairdressing was told on two occasions by the manager of a salon that she was not looking for an employee. Nonetheless, when the young woman asked one of her white friends to apply for the job, the vacancy was still open. After an official investigation involving the French 'High authority for the fight against discrimination and for equality' (HALDE), the manager of the salon declared that she 'felt more comfortable' with white employees because this would better suit her customers. The court found that discrimination had taken place and the manager of the hair salon was fined $€ 3,000$ plus other damages.

- In the UK in 2007, a woman who suffered eight years of racial abuse at a small electronics company where she was the only ethnic minority employee was awarded $£ 34,000$ in compensation by an employment tribunal. She had been referred to as 'nigger', literature from an extreme right-wing political party was placed on her workstation, and colleagues openly discussed the party's anti-immigrant policies in her presence. The tribunal ordered the company to work with the Commission for Racial Equality (now merged into the Equalities and Human Rights Commission) to provide diversity training for all directors and managers. ${ }^{7}$ 


\section{Evidence from research on direct and indirect discrimination}

Discrimination can manifest itself in many subtle ways and is seldom possible to catch in action. Therefore, different types of research methods have been necessary to expose the process of discrimination, such as surveys, participant observation and field experiments.

\section{Victim surveys}

One method to measure and understand discrimination is the victim survey. Such surveys typically consist of questionnaires and interviews that gather information on the victims discrimination experiences (Lange I999, 2000).

There are many examples of quantitative and qualitative victim surveys in EU member states (Hönekopp et al. 2002: 48ff; EUMC 2002d: I9; Lange 1999), and in recent years the amount of victim surveys has been steadily growing in an increasing number of countries. According to these studies, many people with an immigrant background experience discrimination in working life in various ways, often related to their specific origin (Lange 2000). Victim surveys show that most European countries have certain groups that experience more discrimination than others: for instance, groups in France and Sweden from Maghreb countries and in Germany from Turkey (Hönekopp et al. 2002). In the Netherlands, a study commissioned by the Ministry of Justice in 2005 found that around 60 per cent of a representative sample of jobseekers of Moroccan and Turkish backgrounds were of the opinion that they had suffered rejection because of their origins, and a quarter said they had experienced harassment or discrimination in the workplace (Boog et al. 2006). And in a more recent official survey in the same country, focus group interviews revealed that ethnic minority respondents adopt 'coping strategies' in the face of discrimination, such as not mentioning their country of birth (Andriessen et al. 2007).

Discrimination in working life is reported through victim surveys in new EU member states as well. For example, in Estonia in 2005, I7 per cent of ethnic non-Estonian respondents felt that during the previous three years, they had experienced limitations of their rights or maltreatment in the workplace because of their ethnic origin, compared to fewer than 2 per cent of Estonians (Hallik et al. 2006). In Slovenia in 2007, a survey by the government's Office for Equal Opportunities identified inter alia experiences of racial and sexual harassment in the workplace, and also showed that a majority of victims did not report the incident to anyone (Vlada Republike Slovenije 2007).

At the EU level, the Eurobarometer and the European Social Survey include questions related to the experience of discrimination that can be used to develop cross-country comparisons. Nevertheless, these are of limited value because they cover the whole population and therefore 
pick up only a small number of immigrants and minorities. More useful is the 2008 EU-MIDIS survey, which sampled only immigrant/ethnic minority groups on their experiences of discrimination in nine areas of social life, including employment, covering 23,565 people in 27 member states. The results show that reported rates of discrimination are highest among the Roma and those with a Sub-Saharan background, and are also particularly high among those with a North African background. ${ }^{8}$

\section{Surveys on the attitudes or practices of 'gatekeepers'}

In addition to surveys on the discrimination experiences of victims, surveys have been conducted on discrimination practices and attitudes of the majority population that may affect the occurrence of discrimination (Höglund 2002). Such surveys have proved the existence of both indirect and direct forms of discrimination.

One study looked for answers to why antidiscrimination programmes in the Swedish labour market have given such poor results (Nilsson 2006). The study, carried out in six municipalities, focused on the recruitment processes and on the employers' and employees' judgements of the applicants' competences and qualifications. The results clearly showed that recruiters often reason from certain norms, values and routines rooted in the workplace or within a certain occupation, and look for people who are familiar with and who share these styles of thought. This had an impact on how recruiters classified applicants' educational and other formal qualifications. The study showed that certain attitudes can function as the 'gatekeepers' in staff recruitment and negatively affect people who do not have their roots in Swedish culture and are less familiar with companies' styles of thought (Nilsson 2006). In another Swedish study on attitudes of 'gatekeepers' (focusing on the recruitment of managers), the selection process was found to be characterised by a very narrow definition of competence and a limited understanding of possible career paths. Those who were not perceived to have the correct education, work experience and personal characteristics were excluded. What was perceived as 'correct', however, was to a large extent hidden and only 'obvious' for people within the organisation. The study showed that when 'correct' is defined and determined mainly by native-born managers, it can result in ethnic discrimination (Sjölin 2006). Also, regarding indirect discrimination, surveys among employers have revealed that informal recruitment practices through informal social networks can militate against foreignborn jobseekers since they generally lack access to these informal channels (Behtoui 2006b; Segendorf 2005; Knocke et al. 2003; Neergaard 2005). 
While the above examples illustrate practices of exclusion that are to some extent unconscious or unintended, there is also research evidence to indicate direct and intentional discrimination on the part of employers. In Bulgaria in 2005, for example, a study found that 77 per cent of employers would refuse to hire Roma people in construction, agriculture, and other activities requiring low qualifications (Министерски сьвет 2005). In Belgium in 2007, a survey among 688 self-employed individuals found that eight out of ten would not consider hiring a person of foreign nationality, even for occupations for which there are labour shortages (Decoo 2007).

It is likely that these examples often reflect the existence of straightforward 'racist discrimination', i.e. actions by people who act on the basis of their own negative stereotypes about a minority group. Nonetheless, the examples might also reflect 'societal discrimination', i.e. actions by people who are taking into account the assumption that other people have negative attitudes towards a minority group. ${ }^{9}$ For example, in interviews with managers and employers in Germany in 2006, many explained that they might hold back from recruiting 'second-generation' Turkish people because they wanted to avoid negative economic or social consequences due to presumed conflicts between Turkish employees and German clients or between Turkish and German employees (Gestring et al. 2006).

\section{Participant observation}

Another way discrimination has been studied is through the personal experience of the researcher. Such studies were first conducted in the US during the I950s and later became famous in Europe through the German journalist Günter Wallraff. The examinations were carried out by native white men who disguised themselves as a member of a discriminated group, respectively as a black man in the southern states of the US and as a Turkish 'guest worker' in Germany (Griffin I968; Wallraff I986). These studies provided concrete firsthand accounts of the operation of racism and discrimination in the workplace, and in doing so made a large impact on public opinion.

\section{Field experiments}

An increasingly common method to analyse discrimination is the field experiment, such as 'situation testing' or 'matched pair testing'. Here, test persons with comparable merits, age, educational background and work experience but from different ethnic backgrounds apply for the same jobs (Carlsson \& Rooth 2006; Attström 2007; Integrationsverket 2004; Bovenkerk 2000; Bertrand \& Mullainathan 2004). Through such field experiments, quantitative knowledge about direct discrimination during recruitment processes is collected. Many social scientists 
consider recruitment as probably the most critical point when it comes to discrimination in working life.

Field methods can be used to map different grounds of discrimination (due to sex, ethnicity, age, functional disability or sexual orientation), but are mostly used to analyse ethnic discrimination during staff recruitment. As part of the experiment, the 'applicants' might send a written application by mail, or search for a job by phone or in person. If discrimination occurs, a higher proportion of those who belong to the minority group will be excluded during the recruitment process. This may happen at different stages: during the first selection, after the phone call or after the interview (Blank et. al. 2004).

Field experiments were conducted by the ILO in Spain, the Netherlands, Belgium and Germany in the I990s, and more recently in Italy, France and Sweden. Even though there are contextual differences between these countries (regarding the labour market, policies, methods of job searching, etc.) and the studies were conducted in different time frames, the results are clear: evidence for discrimination was found in all countries.

When situation testing was carried out in Italy, the results showed that most ethnic discrimination occurs during the first seconds of jobenquiring phone calls. Since all applicants in the test group shared the same language skills and educational background, the only possible factor that could explain the exclusion of applicants with an immigrant background was the applicants' foreign name. The foreign-named applicants were often rejected directly, not infrequently with the argument that the vacancy was already filled, whereas a subsequent application with an Italian name showed this not to be the case. When it came to face-to-face contact and the job-offering stage, discrimination occurred less frequently.

During the year 2006, researchers in France sent out 6,46I CVs in response to $\mathrm{I}, 340$ job offers in a large-scale field experiment. It turned out that people of Maghreb origin only had 36 chances to be invited for a job interview, compared to Ioo chances for the native French majority. ${ }^{\mathrm{IO}}$ Also in 2006 , an independent Hungarian social research centre carried out tests using phone applications with ethnically identifiable family names, and with testers who announced that they were Roma during the phone call. Results showed Roma applicants had much less success than the others for no other reason than their ethnic identity (TÁRKI 2006). And in 2007 in Greece, field experiments showed that Albanian applicants had a much lower chance of employment than Greeks, and that when they were offered a job, they were offered greatly inferior terms and conditions of employment (Drydakis \& Vlassis 2007). 


\section{Weaknesses in research methods}

The above-described research methods provide both indirect and direct evidence of ethnic discrimination in the labour market, and complement the statistical data on inequality presented earlier. Nevertheless, all of these methods have their particular weaknesses.

Concerning victim surveys, some researchers have found that the self-reporting of discrimination could overstate or understate the occurrence of discrimination (Integrationsverket 2004). For example, research in Germany showed that immigrants overestimated the occurrence of discrimination in comparison with what was shown in situation testing. In contrast, in the Netherlands, discrimination was underestimated by ethnic minorities (Integrationsverket 2006). Therefore, experiences of discrimination do not necessarily reflect actual discrimination.

Attitude studies of the majority rely on the same type of material as victim studies and have similar methodological problems as to what the answers are really telling us, since reported behaviour and actual behaviour do not always correspond. For example, many respondents will give 'socially acceptable' answers. Additionally, people who do not seem to be prejudiced may nevertheless discriminate in practice. It may also be the case that people with prejudices do not, in practice, discriminate because their organisations' recruitment system has been structured in such a way that it is not possible to do so (Höglund 2008).

Participant observation during recruitment processes is advantageous because real daily actions are studied instead of organised actions meant to detect discrimination. Nonetheless, people who know they are being observed may hide information from the observer. As a result, the method may underestimate the level of discrimination. Another even more important weakness of this method is the lack of wider generalisability: how can we know how representative the experiences of just one observer are? (Wrench 2005)

Finally, while discrimination testing is a convincing method for demonstrating the existence of discrimination in recruitment that avoids many of the weaknesses of other research methods, there have been criticisms of this methodology. For instance, it is useful for testing only the first stages of recruitment, and gives no clue as to the motives or forces behind the discrimination. ${ }^{\text {II }}$ Furthermore, it is very difficult to make international comparisons due to the differing characteristics of national labour markets, the differing focus on first- and secondgeneration migrants in these studies, and other differences of methodology and context. Such criticisms, however, do not undermine the major advantage of situation testing - the ability to demonstrate the al- 
most 'pure effect' of a signal of ethnicity or race on recruitment. It provides data on direct discrimination that is unambiguous.

\section{Types of discrimination}

The data and research on the relation between discrimination and labour market opportunities enable us to distinguish between various types of discrimination. ${ }^{{ }^{2}}$ This in turn helps us to understand their underlying processes and causes, and thereby the possible measures that would effectively target discrimination.

The primary distinction frequently made between various forms of discrimination is derived from the legal distinction between 'direct' and 'indirect' discrimination: direct discrimination meaning discriminatory practices that can be traced back to specific persons or actions that explicitly aim to exclude certain groups, and indirect discrimination meaning discriminatory practices that are the consequence of apparently neutral practices or work routines and thus not explicitly aiming to exclude certain groups.

Indirect discrimination is most easily understood with regard to recruitment. For example, the earlier-mentioned practice of recruiting staff primarily through informal social networks constitutes indirect discrimination. In the context of the workplace, this heading could also include the passive adherence to company rules or traditions that do not allow for changed circumstances in the workforce. A rule of 'last in, first out' when staff has to be fired will disproportionately penalise an immigrant workforce of recent duration, and thus could constitute an example of indirect discrimination.

Even the perpetuation of traditional practices such as inflexible dress codes, canteen menus or holiday rules can be potential factors of indirect discrimination in the context of a new multiethnic workforce. The implication of cultural diversity in a workforce may be that 'systems and procedures that are appropriate for some groups may be inappropriate or actually discriminatory if applied to other groups of people' (Stewart \& Lindburgh I997: I4).

Indirect discrimination is sometimes classified as a kind of 'structural' discrimination, in that it cannot be reduced to any particular individual's bias or actions. As Williams (2000) writes, 'Acknowledging the existence of structural discrimination means acknowledging that unjust inequalities exist, but that blame for their existence cannot be assigned to any specific, identifiable individuals' (Williams 2000: 66). Structural discrimination operates through longstanding inequalities, which might have originally stemmed from historical acts of discrimination. The acknowledgement of structural discrimination implies that 
affirmative action policies are necessary to reduce unjustified inequalities, in addition to policies that prevent individuals from carrying out acts of discrimination.

There are other forms of systematic differential treatment that can be argued to be types of discrimination, and that are relevant to the issues dealt with in this volume. These might be labelled 'opportunist discrimination' and 'legal discrimination' (Wrench 2007). Also relevant is the broad concept of 'institutional discrimination'.

Opportunist discrimination is differential treatment, and possible exploitation, based not necessarily on the racism or prejudice of the employer, but on the knowledge that the minority ethnic group is in a weak position in society and in the labour market (perhaps because of the effects of racist or historical discrimination, or the kinds of legal discrimination described below). As a result, these individuals can safely be given inferior working conditions, paid lower wages, etc. An example would be the exploitation of legally restricted or undocumented workers. This type of discrimination does not apply to exclusion at the recruitment stage, as some employers are only too willing to recruit such exploitable workers.

Legal discrimination is found more in some European countries than others. While European antidiscrimination law confers the right to labour without discrimination, including for third-country nationals, there are legal restrictions within some countries that restrict the access of non-nationals to certain occupations, often in the public sector, or restrict the ability to change jobs. Laws and administrative restrictions governing the access of third-country nationals to employment are in principle legitimate, unless it can be proven that discrimination has taken place on the grounds of ethnic or racial origin. Nevertheless, they are instruments that do contribute to inequalities along the lines of social group membership, and are considered by some to be a form of 'legal discrimination'. In some European countries, for example, even long-term immigrant residents still have to rely on a range of restrictive work and residence permits, which severely limit their freedom in relation to majority workers.

It is clear that the concepts of opportunist and legal discrimination are particularly relevant to the circumstances of migrant women in Europe, as discussed in Chapter 3.

\section{Institutional discrimination}

It is argued that while some progress has been made in measures to fight direct and open discrimination, there remains a residue of racial and ethnic inequality that is understood to be partly the result of a combination of more subtle, structural institutional forces rather than 
individual acts of exclusion by identifiable persons. The terms 'institutional racism' or 'institutional discrimination' are sometimes used to describe this.

'Institutional discrimination' within an organisation is likely to refer to established practices over time that can be rooted in a combination of other types of discrimination - for example, it might include direct racist discrimination by some people with racist ideas; there may be routine 'societal' discrimination carried out by people with no racist attitudes, but who are simply following traditions of recruitment; there may be routine practices of indirect discrimination; a failure to understand and make allowances for historical discrimination, and all this could occur in a national context of broader legal discrimination. All of these might come together over time to characterise the organisation's common practices, which may result in institutional discrimination becoming part of an organisational culture (Wrench 2007).

This clarification of various types of discrimination is important because it has direct implications for the kinds of antidiscrimination measures that are to be employed. For example, types of direct intentional discrimination might be tackled by awareness-raising activities or the policing of behaviour, whereas the recognition of historical forms of structural discrimination suggests the necessity of positive action policies. Legal discrimination, on the other hand, requires government action to change laws. And when various forms of racism and discrimination crystallise into a longstanding organisational culture of institutional discrimination, this constitutes one of the targets of a diversity management policy, given that the long-term goal of such a policy is often stated to be the production of a new organisational culture (see Chapter 5).

\section{Conclusions}

In this chapter, we have focused on data that presents inequality in the labour market, in relation to both access to the labour market and working conditions, and also on research revealing the occurrence of discrimination in different countries.

Statistics and national studies have shown that unemployment rates are much higher among foreign-born people and that working conditions differ between native- and foreign-born people in most European countries. The latter translates into insecure terms of employment, temporary employment, limited access to in-service training and lower wages for similar work. Research has also shown that it is not profitable for highly educated people to accept a lower position than the one for which they are educated. Furthermore, there are differences de- 
pending on supply and demand: when there are many job openings, unemployment among highly educated immigrants will decrease. This is consistent with the idea that immigrants serve as a buffer on the labour market and are therefore more sensitive to economic fluctuations than the native population. In addition, national studies showed that certain minority groups, such as people from North Africa, suffer disproportionately and are most often unemployed or working in low-paid jobs.

It is not possible to stipulate unambiguously that discrimination is at the root of the problem on the basis of statistical patterns alone. Many other factors may explain the inequality, such as differences in qualifications or in length of time of residence and changes in the labour market. Nonetheless, when statistical patterns are combined with the evidence from various types of research, a strong indication of real discrimination emerges. Victim studies reveal that many immigrants report firsthand experiences of discrimination. Studies of gatekeepers reveal attitudes and practices of direct discrimination. 'Situation testing' experiments demonstrate that having a foreign name is enough reason for exclusion even if competences and experiences are similar to applicants with indigenous-sounding names.

While it is difficult to make meaningful comparisons when labour markets and the wider context differ from country to country, the results from investigations within different countries show that discrimination occurs in all countries where research has been carried out. Situation testing research confirms that it is the first phase in recruitment, the application, which is the most problematic for people of immigrant and ethnic minority backgrounds.

Part of discrimination has been shown to occur indirectly through routines and regulations, networks and norms, which lead to the exclusion of some applicants. Even if the purpose is not to exclude people with other ethnic backgrounds, the dominant way of thinking and acting leads to such a result. People with a mother tongue other than the dominant one, and those who have a foreign education will have problems finding employment to match their expectations. And with regard to indirect discrimination, various studies show that those who lack the necessary social networks have restricted opportunities when looking for work, since a majority of jobs are mediated through informal contacts typically accessed by the native population. These phenomena form part of what has been called 'institutional discrimination', which includes the normal routines and regulations within organisations that affect immigrants and ethnic minorities more than the native majority.

To sum up, the evidence described in this chapter indicates that there are factors which, regardless of the abilities and achievements of 
the individuals themselves, have a negative influence on their participation in the labour market. Access to the labour market differs between descendants of natives and immigrants, and has been shown to be at least partially determined by phenotypical and cultural characteristics that differ from the majority native population.

It is possible for employers to respond to what has been mentioned here only if they are made aware of it, and research has a role in this. It is not only the excluded individuals who have something to gain from the removal of barriers of discrimination; employers have a lot to gain as well. They need to be more aware of the advantages of recruiting from a broader labour base, and the improvement in the retention and utilisation of this labour that can be achieved through policies of antidiscrimination and diversity management.

\section{Notes}

I The views expressed in this chapter are those of John Wrench and his co-author, and not those of the EU Agency for Fundamental Rights.

2 See www.dailymail.co.uk/news/article-Io8I42I/Financial-crisis-send-millionimmigrant-workers-home-race-chief-says.html.

3 See www.irrawaddy.org/article.php?art_id $=$ I452I and www.ituc-csi.org/spip.php?article2486.

4 It should be noted that there is a wide variety between EU member states regarding the minimum periods of legal residence required to obtain citizenship, ranging from three to ten years (FRA 2007: 43).

5 On this crucial topic, see Simon 2004, Mannila 2005, Rallu et al. 2006 and Simon 2007.

6 See the recommendations in a recent report for the European Commission: 'How to measure progress in combating discrimination and promoting equality?', DG ESAEO 2008, http://ec.europa.eu/social/BlobServlet?docId=770\&langId=en.

7 The case is described at: www.personneltoday.com/Articles/2007/07/18/41568/ pauline+taylor+wins+34000+compensation+after+suffering+eight+years+of+racial +abuse.html, I6 October 2007.

8 See www.fra.europa/eu-midis.

9 For further discussion of these types of discrimination, see Wrench 2007: II6-I22.

Io See www.cergors.univ-parisı.fr/docsatelecharger/Barometrezoo6resultats.pdf, I4 June 2007.

II See Banton 1994 on ethics, Heckman 1998 on economic assessment and Simon \& Stavo-Debauge 2004 on antidiscrimination policies.

I2 This section looks at different types of discrimination, drawing on Wrench 2007: II6-I22.

\section{References}

Algemene Directie Werkgelegenheid en Arbeidsmarkt/Direction générale Emploi et Marché du Travail (2006), 'De Immigratie in België: Aantallen, Stromen en Arbeids- 
markt - Rapport 2006/L'immigration en Belgique: Effectifs, Mouvements et Marché du Travail - Rapport 2006: 36 .

Andriessen, I., J. Dagevos et al. (2007), Discriminatiemonitor niet-westerse allochtonen op de arbeidsmarkt 2007, Den Haag/Rotterdam: Sociaal en Cultureel Planbureau, Art.I.

Arai M., R. Håkan \& L. Schröder (I999), 'Är arbetsmarknaden öppen för alla?’ Bilaga 6, Långtidsutredningen 2000. Stockholm: Fritzes.

Aronsson, G., M. Dallner \& K. Gustafsson (2000), 'Yrkes- och arbetsplatsinlåsning. En empirisk studie av omfattning och hälsokonsekvenser'. Arbete och hälsa 5. Stockholm: Arbetslivsinstitutet.

Attström, K. (2007), Discrimination against native Swedes of immigrant origin in access to employment. A research study on Stockholm, Malmö and Gothenburg, utilizing the ILO discrimination practice testing approach. ILO: Geneva. www.ilo.org/public/english/ protection/migrant/download/imp/imp86e.pdf

Banton, M. (I994), Discrimination. Buckingham: Open University Press.

Behtoui, A. (2006a), Unequal opportunities: the impact of social capital and recruitment methods on immigrants and their children in the Swedish labour market. Linköping: Department of Social and Welfare Studies.

Behtoui, A. (2006b), Om de hade föräldrar födda på 'rätt plats' - om ungdomar med utländsk bakgrund $i$ det svenska utbildningssystemet och på den svenska arbetsmarknaden, Expert bilaga till Rapport integration 2005, Norrköping: Integrationsverket.

Bertrand, M., D. Chugh \& S. Mullainathan (2004), 'Implicit discrimination', The American Economic Review 95 (2): 94-98, Papers and Proceedings of the $\operatorname{II}^{\text {th }}$ Annual Meeting of the American Economic Association, Philadelphia, PA, 7-9 January 2005.

Blank, R., M. Dabady \& C. F. Citro (2004), Measuring Racial Discrimination. Washington, DC: National Academies Press.

Boog, I. et al. (2006), Monitor rassendiscriminatie 2005. Rotterdam: National Bureau against Racial Discrimination.

Botcherby, S. (2006), Pakistani, Bangladeshi and Black Caribbean women and employment survey: aspirations, experiences and choices. Manchester: Equal Opportunities Commission. http://83.137.212.42/sitearchive/eoc/PDF/bme_gfi_women_employment_survey. pdf?page $=$ I947I (I7.I0.2007).

Bovenkerk, F. (2000), 'The research Methodology I3-40', in R. Zegers de Beijl (ed.), Documenting Discrimination Against Migrant Workers in the Labour Market. A Comparative Study of Four Countries. Geneva: International Labour Office.

Burkert, C. \& H. Seibert (2007), 'Labour market outcomes after vocational training in Germany. Equal opportunities for migrants and natives?', IAB Discussion Paper No. 3I.

Carlsson, M. \& D. O. Rooth (2006), 'Evidence of Ethnic Discrimination in the Swedish Labour Market Using Experimental Data', IZA Discussion Paper No. 228I. Bonn: IZA.

Central Statistics Office (2004), National Census 2002 - Irish Traveller Community, released 29 January 2004.

Decoo, S. (2007), 'Zelfstandigen zien allochtone werknemers niet graag komen', in De Morgen, I7 March 2007, p. 3.

Drydakis, N. \& M. Vlassis (2007), Ethnic Discrimination in the Greek Labour Market: Occupational Access, Insurance Coverage, and Wage Offers, University of Crete Working Paper. http://econpapers.repec.org/paper/crtwpaper/0715.htm, 30 November 2007.

Ekberg, J. \& D. O. Rooth (2004), Yrke och utbildning på 2000-talets arbetsmarknad - skillnad mellan inrikes och utrikes födda personer. Norrköping: Expertbilaga, Rapport Integration 2003 .

EUMC (2006), Annual report on the Situation regarding Racism and Xenophobia in the member States of the EU. EUMC: Vienna.

http://eumc.europa.eu/eumc/material/pub/aro6/ARo6-P2-EN.pdf. 
EUMC (2002a), 'Migrants, Minorities and Employment in Belgium. Exclusion, discrimination and antidiscrimination', Raxen 3 Report to the European Monitoring Centre on Racism and Xenophobia (EUMC).

EUMC (2002b), 'Migrants, Minorities and Employment in Finland. Exclusion, discrimination and antidiscrimination', Raxen 3 Report to the European Monitoring Centre on Racism and Xenophobia (EUMC).

EUMC (2002C), 'Migrants, Minorities and Employment in the UK. Exclusion, discrimination and antidiscrimination', Raxen 3 Report to the European Monitoring Centre on Racism and Xenofobia (EUMC).

EUMC (2002d), 'Migrants, Minorities and Employment in Denmark. Exclusion, discrimination and antidiscrimination', Raxen 3 Report to the European Monitoring Centre on Racism and Xenophia (EUMC).

EUMC (2005), Racism and Xenophobia in EU Member States: trends developments and good practice: Annual Report 2005, European Monitoring Centre on Racism and Xenophobia, Vienna

Forsythe, R., J. L. Horowitz, N. E. Salvin \& M. Sefton (I994), 'Fairness in Simple Bargaining Experiments', Games and Economic Behavior 6: 347-369.

FRA (2007), Report on Racism and Xenophobia $n$ the Member States of the EU. Vienna: FRA.

Fridholm, A. (2006), Den mångkulturella marknaden 2006. En studie av invandrarnas köpkraft. Stockholm: Timbro.

Gestring, N., A. Janssen \& A. Polat (2006), Prozesse der Integration und Ausgrenzung. Türkische Migranten der zweiten Generation, I35-I93. Wiesbaden: VS Verlag für Sozialwissenschaften.

Griffin, J. H. (I968), Svart som en nigger. Stockholm: Rabén \& Sjögren.

Hallik, K. et al. (2006), Estonia: Interethnic Relations and the Issue of Discrimination in Tallinn, 39. Tallinn: LICHR.

Heckman, J. (I998) 'Detecting discrimination' Journal of Economic Perspectives I2: IOI-II6.

Höglund, S. (2002), 'Invandrarna och arbetsmarknaden' in L. H. Hansen \& P. Orban (eds.), Arbetslivet, 40I-435. Lund: Studentlitteratur.

Höglund, S. (2008) 'Etnisk diskriminering I arbetslivet', in M. Darvishpour \& C. Westin (eds.), Migration och etnicitet. Perspektiv på ett mångkulturellt Sverige. Lund: Studentlitteratur.

Hönekopp, E., G. Will \& S. Rühl (2002), 'Migrants, Minorities and Employment in Germany', Raxen 3 Report to the European Monitoring Centre on Racism and Xenophobia (EUMC).

Houtzager, D. \& P. R. Rodrigues (2002), 'Migrants, Minorities and Employment in the Netherlands. Exclusion, discrimination and antidiscrimination', Raxen 3 Report to the European Monitoring Centre on Racism and Xenophobia (EUMC).

Integrationsverket (2004), Tillämpningen av Situation testing - metodologi $i$ analysen av Arbetsmarknadsdiskriminering. Norrköping: Integrationsverket.

Integrationsverket (2006), Rapport integration 2005. Norrköping: Integrationsverket.

Inter-ministerial Commission for Roma Community Affairs (2005), Report on the situation of Roma communities in the Czech Republic in 2004, acknowledged by the government on 9 March 2005. http://wtd.vlada.cz/scripts/detail.php?id=772I.

Klaver, J. \& A. Odé (2005), 'Een weg vol obstakels: de moeizame integratie van vluchtelingen op de Nederlandse arbeidsmarkt', in Migrantenstudies 2005 (2): IO2-II8.

Knocke, W. \& F. Hertzberg (2003), Retorik och praktik i rekryteringsprocessen. Stockholm: Arbetslivsinsitutet.

Lange A. (I992), 'Begreppet diskriminering', in Diverse skrifter. Stockholm: CEIFO. 
Lange A. (I999), Invandrare om diskriminering IV: en enkät- och intervjuundersökning om etnisk diskriminering på uppdrag av Diskrimineringsombudsmannen (DO). Stockholm: CEIFO.

Lange A. (2000), Diskriminering, integration och etniska relationer. Norrköping: Integrationsverket.

Langenberg, H. \& H. Lautenbach (2007), 'Beroepsniveau niet-westerse allochtonen lager', in Sociaaleconomische trends I: 37-45.

Le Grand, C. \& S. Ryschard (I999), 'Invandrarnas löner i Sverige', in Arbetsliv och arbetsmarknad. Stockholm: Arbetslivsinstitutet.

Manfredi, A. (2007), 'Aosta, 'Sei di colore, in sala non vai bene', ristoratore rifiuta di assumere ragazza', La Repubblica.it, 4 January 2007. www.repubblica.it/2007/oI/sezioni/cronaca/eliana-cau/eliana-cau/eliana-cau.html.

Mannila, S. (ed.) (2005), Data to Promote Equality, European Commission / Finnish Ministry of Labour, Helsinki

Meurs, D., A. Pailhé \& P. Simon (2006), 'The Persistence of Intergenerational Inequalities Linked to Immigration: Labour Market Outcomes for Immigrants and Their Descendants in France, Populations 20065 (6), www.cairn.info/load_pdf.php?ID_ARTICLE=POPE_605_0645.

Muus, P. (2002), Migration, immigrants and labour markets in EU countries. ThemES, occasional papers and reprints on ethnic studies 3. University of Linköping: Centre for Ethnic and Urban Studies (CEUS). www.ceus.nu/themes/THEMESo32002.pdf.

Neergaard, A. (2005), 'Rasifierad rekrytering i storstadskommunen: Mellan exkluderad och inkluderad underordning', in E. Gunnarsson, A. Neergaard \& A. Nilsson (eds.), Skillnader på kors och tvärs: Arbetsliv, storstad och makt. Stockholm: Normal.

NEKI (2007), Fehér Füzet 2006. www.neki.hu/index.php?option=com_docman\&task=cat_view\&gid=32\&Itemid=45; www.neki.hu/index.php?option=com_content\&task=view\&id=3II\&Itemid=I; www.neki.hu/index.php?option=com_content\&task=view\&id=20\&Itemid=I, II October 2007).

Nilsson, A. (2006), Gränsvakter: tankestilar och sortering vid rekrytering av personal $i$ sex kommuner. Stockholm: CEIFO.

OECD (200I), Employment outlook. Paris: OECD.

OECD (2005), Employment outlook. Paris: OECD.

Rallu J.L., Piché V. \& Simon P. (2006), 'Demography and Ethnicity: An Ambiguous Relationship’, in Graziella Caselli, Jacques Vallin et Guillaume Wunsch, éd. Demography: Analysis and Synthesis. A Treatise in Population Studies. Volume 3. Elsevier, Academic Press : 53I-549.

Rooth, D. O. \& J. Ekberg (2006), 'Occupational Mobility for Immigrants in Sweden', International Migration 44 (2): 57-77.

Rooth, D. O. (200I), 'Etnisk diskriminering och “Sverige-specifik” kunskap', Ekonomisk Debatt 29 (8): 535-546.

Schröder, L. \& R. Vilhelmsson (2000), 'En svartvit arbetsmarknad?', ESO-rapport om vägen från skola till arbete. Stockholm: Fritzes.

Segendorf, Å. O. (2005), Job search strategies and wage effects for immigrants. Stockholm: Swedish Institute for Social Research (SOFI).

Silberman R. \& I. Fournier (2006), 'Les secondes générations sur le marché du travail en France : une pénalité ethnique ancrée dans le temps', Revue française de sociologie $2006(2)$.

Silberman, R., R. Alba \& I. Fournier (2007), 'Segmented assimilation in France? Discrimination in the labour market against the second generation', Ethnic and Racial Studies 30 (I): I-27. 
Simon P. (2004), Comparative study on the collection of data to measure the extent and impact of discrimination within the United States, Canada, Australia, the United Kingdom and the Netherlands, Rapport à la commission européenne, DG Emploi et Affaires sociales, Droits fondamentaux et antidiscrimination, Luxembourg. http://europa.eu.int/ comm/employment_social/fundamental_rights/pdf/pubst/compstudo4_en.pdf

Simon P. (2007), Ethnic statistics and data protection, report for ECRI, European Council, Strasbourg, June 2007

Simon P. \& J. Stavo-Debauge (2004), 'Les politiques anti-discrimination et les statistiques: paramètres d'une incohérence', Sociétés Contemporaines, 53/2004, p.57-84

Sjögren, L. (2004), Invandrares upplevelse av diskriminering. En studie av anmälningar till DOK gällande etnisk diskriminering $i$ svenskt arbetsliv. Uppsats 484. Umeå: Umeå Universitet, Sociologiska institutionen.

Sjölin, T., S. Rönnqvist, C. Ljungberg \& P. Broomé (2006), Chefsrekrytering i Malmö stad - En fallstudie om kompetens, mångfald och homogenisering. Norrköping: Integrationsverket.

Stewart, M. \& L. Lindburg (1997), Gaining from Diversity. Brussels: European Business Network for Social Cohesion.

TÁRKI (2006), Az esélyegyenlőség érvényesülése az önkormányzatoknál.

Van den Maagdenburg, V. (2004) 'Arbeid en Inkomen', in Jaarrapport Integratie 2004, Instituut voor Sociologisch-Economisch Onderzoek.

VDAB (2007), VDAB ontcijfert nummer 3. www.vdab.be/trends/ontcijfert/ontcijfert2007nr3.pdf, i5 January 2008.

Veenman, J. \& J. van Ours (2002), 'From Parent to Child: Early Labour Market Experiences of Second-Generation Immigrants in the Netherlands', IZA Discussion Paper 649, Institute for the Study of Labour (IZA).

Vlada Republike Slovenije, Urad za enake možnosti (2007), Sexual and other harassment at the workplace.

www.uem.gov.si/fileadmin/uem.gov.si/pageuploads/RaziskavaNadlegovanje.pdf, I5 October 2007.

Wallraff, G. (I986), Längst dür nere. Stockholm: Norstedts.

Williams, M. S. (2000), 'In Defence of Affirmative Action: North American Discourses for the European Context?', in E. Appelt \& M. Jarosch (eds.), Combating Racial Discrimination: Affirmative Action as a Model for Europe. Oxford: Berg.

Wrench, J. (2005), 'The Measurement of Discrimination: Problems of comparability and the role of research' in S. Mannila (ed.), Data to Promote Equality, European Commission/Finnish Ministry of Labour, Helsinki, p. 56-76

Wrench, J. (2007), Diversity Management and Discrimination: Immigrants and Ethnic Minorities in the EU. Aldershot: Ashgate.

Министерски съвет (2005) Годишен доклад за младежта на Република България за 2005 г. (12 април 2006 г.). www.youthdep.bg/base/d2005.pdf. 


\title{
3 Migrant and minority women, inequalities and discrimination in the labour market
}

\author{
Eleonore Kofman, Judith Roosblad and Saskia Keuzenkamp ${ }^{\mathrm{I}}$
}

\section{Introduction}

While race and ethnicity are central dimensions of inequalities in the labour market, they also intersect with other dimensions of social inequality such as gender, age, disability and sexuality.

Not only do migrant and ethnic minority workers have fewer opportunities in the labour market than their indigenous counterparts, but research has shown that the cumulative effects of gender and ethnic inequalities lead to a gender stratification in which native men have the best opportunities, and migrant and minority women have the most disadvantaged positions in many EU member states. Their employment is heavily concentrated in particular segments of the market characterised by low pay, low status and insecure jobs (EUMC 2003). The lack of contracts and the informality of their work, especially in the form of household help, mean that they are either not covered by antidiscrimination legislation or are unable to make use of it. Migrant and ethnic minority women are by no means a homogeneous group, and differ by demographic characteristics, nationality, education, skills, religion, legal status, duration of residence and employment.

Native women share some of the characteristics of migrant women, although to a far lesser degree. They tend to be concentrated to a greater extent than men in a few sectors and to be paid less than men. These characteristics can be attributed to structural problems within sectors and occupational gender segregation, gender-specific employment patterns such as part-time work, structural inequalities in access to education and training, biased evaluation and pay systems and stereotypes. Evidence suggests that the pay gap is even worse for ethnic minority women (EOC 2007; Zorlu 200I).

According to the 2008 EU Report on Equality between Women and Men, female employment has been the main factor in the steady growth of employment in the EU in recent years. The female employment rate has gone up each year, reaching 57.2 per cent in 2006, 3.5 percentage points higher than in 2000. The male employment rate rose as well in this period, but only by less than one point. Although 
female labour participation has increased in general, that of migrant and ethnic minority women is still lagging behind. In 2003, their employment rate was $\mathrm{I} 6.9$ percentage points lower than that of EU nationals. Among highly-skilled migrant women, it was even 23.2 points lower (EC 2005).

In their study on the participation of immigrant women in the labour market, Dumont and Isoppo conclude that individual characteristics such as education, mode of entry, duration of residence and skills alone do not explain the labour market participation of migrant and ethnic minority women, and that we should therefore not overlook the impact of discrimination on their participation (Dumont \& Isoppo 2005: 3).

In recent years, the EU has increasingly turned its attention to issues of the participation of and challenges faced by migrant women in the labour market. The European Commission has acknowledged that getting a better understanding of migrant women in the labour market is a key condition to developing appropriate policy responses to the problems faced by migrant women.

While the EU is moving towards addressing these multiple inequalities (Verloo 2006), a long history of treating different forms of inequality separately has made it difficult to understand and recognise the ways in which they dynamically interact. EU policies and the legal framework against discrimination are still fragmented: discrimination on the basis of race is covered by different directives and programmes than discrimination on the basis of gender. Furthermore, gender as grounds for discrimination is in fact excluded from the 2000 antidiscrimination directives and from the programme to combat discrimination. In its first migration and integration report, however, the European Commission has recognised that the systematic mainstreaming of gender issues seems to be lacking in most member states' immigration policies and data (COM 2004).

In addition, the lack of appropriate methodological tools for studying intersectionality contributes to the tendency in literature to treat gender and ethnicity separately and then add them together, overlooking possible cumulative effects (McCall 2005).

In this chapter, we will examine the labour market opportunities of migrant and ethnic minority women in comparison to native women and both migrant and native men. To start off, we will provide an overview of ethnic and gender differences in labour market participation and unemployment rates. We will then take a closer look at differences in sectors of employment, income, working conditions and terms of employment. We will proceed to highlight inequalities related to legal status, which are tied to immigration and integration policies. Immigration policies do not just formally sanction different positions, but they 
also have different impacts regarding gender that play themselves out in the labour market. To conclude, we will attempt to explore the extent to which discrimination can account for the multiple inequalities migrant and minority women face.

\section{Labour participation and unemployment of men and women, both migrant and native}

It is not easy to offer a good overview of the position of migrant and ethnic minority women in the labour market. Often, research on the labour market participation of ethnic minorities only pays minor attention to differences between women and men. In research on the gendered character of labour, ethnic differences often get little attention. There are some studies on migrant and ethnic minority women, but often their labour participation is only compared with that of native women and not with that of men from their own group. Another problem is that much of the international comparative data is only on the first generation, defined as people who are born outside the country of residence. As a result, we learn very little about how the second generation fares in different countries. Generally speaking, however, the second generation has higher participation rates and a better position in the labour market than the first. An important explanation is of course that the second generation is educated in the country of residence, so the human capital of these people is of greater value than that of their parents (OECD 2008).

In other studies, nationality is used as a marker to distinguish between groups, leaving members of ethnic minority groups who have gained the nationality of their country of destination out of the picture. Moreover, countries have different regulations concerning naturalisation, which can hinder international comparisons.

As a consequence, most of the international comparative data we present in our chapter does not show the whole picture of ethnic minority women in the labour market. Comparisons are often made between nationals and non-nationals, or between those who were born inside or outside the country of residence. Now and then, we will add extra information about the second generation, mostly stemming from studies in one particular country.

In many European countries, male non-nationals have lower participation rates than nationals, but the participation rates of foreign women are especially low, both when compared to foreign men and to indigenous women (Table I). In 2000-200I, the participation rates of foreign women were the lowest in Belgium, France and the Netherlands. 
In all three countries, native women and foreign men participated in the labour market far more often.

In almost all European countries, foreigners are more often unemployed than nationals and the situation of foreign women is the worst in most countries. In 2000-200I, the highest unemployment rates for foreign women were found in Finland, France and Italy.

Table 3.1 Labour force participation rate (\%) and unemployment rate (\%) of nationals and foreigners, by gender, in selected OECD countries, 2000-2001

\begin{tabular}{|c|c|c|c|c|c|c|c|c|}
\hline & \multicolumn{4}{|c|}{ Participation rate } & \multicolumn{4}{|c|}{ Unemployment rate } \\
\hline & \multicolumn{2}{|l|}{ Men } & \multicolumn{2}{|l|}{ Women } & \multicolumn{2}{|l|}{ Men } & \multicolumn{2}{|l|}{ Women } \\
\hline & Nationals & Foreigners & Nationals & Foreigners & Nationals & Foreigners & Nationals & Foreigners \\
\hline Austria & 78.9 & 85.1 & 62.4 & 63.3 & 3.9 & 8.4 & 3.9 & 8.6 \\
\hline Belgium & 73.3 & 72.4 & 57.0 & 41.0 & 4.6 & 14.2 & 7.0 & 16.5 \\
\hline Czech Republic & 78.7 & 87.8 & 63.3 & 56.3 & 7.1 & 7.6 & 10.1 & 12.5 \\
\hline Denmark & 84.1 & 71.2 & 76.2 & 53.0 & 3.6 & 12.2 & 4.9 & 7.2 \\
\hline Finland & 79.4 & 83.1 & 74.6 & 60.2 & 10.0 & 24.2 & 11.2 & 29.9 \\
\hline France & 75.1 & 76.6 & 63.3 & 48.6 & 7.1 & 17.1 & 10.7 & 23.9 \\
\hline Germany & 78.9 & 77.6 & 64.7 & 50.7 & 7.2 & 13.4 & 7.8 & 11.7 \\
\hline Greece & 76.2 & 89.2 & 49.0 & 56.0 & 7.2 & 7.6 & 16.2 & 17.6 \\
\hline Hungary & 67.6 & 77.8 & 52.2 & 51.8 & 6.4 & & 4.9 & 5.5 \\
\hline Ireland & 79.2 & 77.0 & 55.9 & 56.2 & 4.1 & 5.1 & 3.8 & 6.2 \\
\hline Italy & 73.6 & 87.7 & 46.6 & 50.7 & 8.0 & 7.4 & 13.9 & 21.3 \\
\hline Luxembourg & 74.0 & 79.7 & 47.7 & 57.7 & 1.2 & 2.5 & 1.7 & 3.8 \\
\hline Netherlands & 84.9 & 69.5 & 67.2 & 49.0 & 1.9 & 4.7 & 2.9 & 7.0 \\
\hline Norway & 84.6 & 82.1 & 76.8 & 67.2 & 3.7 & 5.3 & 3.4 & 4.5 \\
\hline Portugal & 79.0 & 81.5 & 64.0 & 65.3 & 3.1 & 8.4 & 5.1 & 9.6 \\
\hline Slovakia & 76.9 & 79.4 & 63.2 & 51.8 & 19.8 & 26.2 & 18.6 & 17.0 \\
\hline Spain & 77.3 & 85.4 & 50.9 & 59.1 & 9.3 & 12.9 & 19.8 & 17.2 \\
\hline Sweden & 78.0 & 63.1 & 74.2 & 60.3 & 5.5 & 16.1 & 4.6 & 13.0 \\
\hline Switzerland & 89.2 & 89.5 & 73.3 & 68.6 & .3 & 4.3 & 2.6 & 6.4 \\
\hline United Kingdom & 83.1 & 75.6 & 68.4 & 55.8 & 5.5 & 9.8 & 4.4 & 7.9 \\
\hline
\end{tabular}

Source: Labour Force surveys, Eurostat, quoted in OECD/SOPEMI 2002, as presented by Steinhilber 2004

In this table, all foreigners are grouped together, but there are sizeable differences according to the country of origin. Immigrants from nonOECD countries tend to have lower participation rates and higher unemployment rates than immigrants from within the OECD area. Dumont and Liebig (2008) analysed the gap in employment rates between native women and women who were born in non-OECD countries in 2004. They show that the difference in employment rates was largest in the case of Ireland, but also very high (a gap of 20 per cent or more) in the Scandinavian countries, in Germany, the Netherlands and Poland.

A problem often faced when trying to distinguish between different ethnic groups within countries is that their numbers in the datasets 
are too small. Van Tubergen and Maas (2004) solved this problem by adding Io years in one dataset. Table 2 shows the labour participation rates of foreign women (aged 25-64) both by country of origin and country of destination. If we look at Moroccan women, for example, we can see that on average 45.3 per cent participated in the labour market in the period I992-200I in the EU-I5. Nonetheless, their participation rate was much lower in Belgium, Germany and the Netherlands. Looking at differences within countries and taking Belgium as an example, Van Tubergen and Maas showed that on average, the participation of foreign women is 46.5 per cent. It is lowest among Turkish women (25.7 per cent), followed by Moroccan women ( 28.8 per cent). In the Netherlands, Turkish women are more often active in the labour market (34.I per cent) than Turkish women in Belgium. And other than in Belgium, Turkish women are more often active in the labour market than women from Morocco.

Of course these figures raise lots of questions as to how all these kinds of differences can be explained. Generally speaking, several clusters of factors are of importance. Differences in individual characteristics of the groups can play a role (for example concerning their human capital), as can differences in characteristics of the country of origin or the country of destination (Van Tubergen 2005). In addition, differences in gender role attitudes between various groups of migrants can also have an effect. Moreover, diverse policies in countries contribute to diverse outcomes, as we will discuss later on.

Table 3.2 Labour participation rates (\%) of foreign women 25-64 years of age, by country of origin and country of destination (selection of countries and mean of EU-15), 1991-2001

\begin{tabular}{lcccccccccc}
\hline Country of origin & \multicolumn{1}{l}{ Country of destination } \\
\cline { 2 - 11 } & $A T$ & $B E$ & $D K$ & $F R$ & $G E$ & NL & SP & SE & UK & $\begin{array}{c}\text { Mean } \\
\text { EU-15 }\end{array}$ \\
\hline Italy & 40.7 & 37.7 & & 52.4 & 61.9 & 48.1 & 46.5 & & 63.0 & 50.5 \\
Morocco & & 28.8 & 37.2 & 50.8 & 22.1 & 27.7 & 43.2 & & 47.4 & 45.3 \\
Poland & 68.7 & 48.3 & 75.2 & 62.8 & 54.4 & 61.2 & 60.8 & 69.8 & 58.1 & 59.5 \\
Portugal & & 59.3 & & 73.8 & 55.5 & 64.8 & 45.9 & & 65.7 & 69.4 \\
Spain & 56.9 & 49.4 & 87.1 & 55.1 & 61.6 & 66.8 & & 72.4 & 68.1 & 56.7 \\
Turkey & 54.3 & 25.7 & 41.6 & 33.6 & 48.8 & 34.1 & & 46.8 & 33.4 & 38.5 \\
Former Yugoslavia & 73.2 & 42.9 & 43.2 & 69.0 & 68.0 & 52.7 & 48.5 & 53.5 & 49.9 & 65.4 \\
Mean & 64.0 & 46.5 & 65.1 & 59.2 & 57.9 & 54.8 & 58.2 & 67.2 & 60.2 & 59.0 \\
\hline
\end{tabular}

Source: Van Tubergen \& Maas 2004, Tables 3.4 and 3.6

If we look at the labour participation of different groups of foreign women, it is important to take that of native women into account as well. 
It is well known that native women in the Scandinavian countries participate in the labour market much more than those in other European countries. Considering the low labour participation rate of Turkish women on average, it is quite conceivable that the ratio between foreign women and native women is smaller in Sweden than for example in Austria and Germany, where native women participate in the labour market much less. This is indeed the case, although the difference between Sweden and the EU mean is small (0.56 compared to 0.62 ). Moreover, the assumption is not always true that in countries where native women have high participation rates, the ratio to foreign women will be relatively small. For example, the ratios of Turkish women to native women in Sweden and the Netherlands are quite comparable, while native Dutch women are much less active in the labour market.

Table 3.3 Ratios of labour participation between female migrants and native women, 25-64 years of age, by country of origin and country of destination (selection of countries and mean of EU-15), 1991-2001

\begin{tabular}{|c|c|c|c|c|c|c|c|c|c|c|}
\hline \multirow[t]{2}{*}{ Country of origin } & \multicolumn{10}{|c|}{ Country of destination } \\
\hline & AT & $B E$ & $D K$ & $F R$ & $G E$ & $N L$ & $S P$ & $S E$ & $U K$ & $\begin{array}{l}\text { Mean } \\
\text { EU-15 }\end{array}$ \\
\hline Italy & .63 & 0.62 & & 0.74 & 0.91 & 0.76 & 0.94 & & 0.91 & 0.82 \\
\hline Morocco & & 0.47 & 0.47 & 0.72 & 0.32 & 0.44 & 0.87 & & 0.68 & 0.73 \\
\hline Poland & 1.06 & 0.79 & 0.96 & 0.89 & 0.80 & 0.97 & 1.23 & 0.83 & 0.83 & 0.96 \\
\hline Portugal & & 0.97 & & 1.05 & 0.81 & 1.03 & 0.93 & & 0.94 & 1.12 \\
\hline Spain & 0.88 & 0.81 & 1.11 & 0.78 & 0.90 & 1.06 & & 0.86 & 0.98 & 0.92 \\
\hline Turkey & 0.84 & 0.42 & 0.53 & 0.48 & 0.72 & 0.54 & & 0.56 & 0.48 & 0.62 \\
\hline Former Yugoslavia & 1.13 & 0.70 & 0.55 & 0.98 & 1.00 & 0.83 & 0.98 & 0.64 & 0.72 & 1.06 \\
\hline $\begin{array}{l}\text { Participation rate } \\
\text { natives (\%) }\end{array}$ & 64.7 & 60.9 & 78.4 & 70.5 & 68.1 & 63.2 & 49.4 & 83.9 & 69.6 & 61.9 \\
\hline
\end{tabular}

Source: Van Tubergen \& Maas 2004, Tables 3.5 and 3.7

Due to the data limitations we mentioned before, international comparative figures on the labour participation of the second generation are hard to obtain. Only those who have a foreign nationality but were born in the country of residence are sometimes included in the data that is available. Nonetheless, Liebig's analysis of the European Community Labour Force Survey (Liebig 2007) shows that in most of the countries that he looked at, the employment rates of 'native-born nonnationals' are still lower than those of 'native-born nationals'. Dutch studies show that there are differences between groups from different ethnic backgrounds. Turkish and Moroccan women from the second generation have higher employment rates than those of the first. Members of the second generation are often still young and in school, 
although some of them already work. Turkish and Moroccan women of the first generation have a very low participation rate, so even although members of the second generation are relatively young and sometimes still in school, their participation rate can easily surpass that of the first generation. By contrast, the participation rate among first-generation Surinamese and Antillean women is much higher, so only when most of the members of the second generation have left school will their participation rate surpass that of the first (Merens 2006).

In Germany, there has been a deterioration in the employment rates of 'native-born foreigners' relative to those of German natives (Table 4). Especially second-generation women show a worrisome development: their employment rate reaches just a little more than 75 per cent of that of the natives of the same age group (Liebig 2007).

Table 3.4 Evolution of employment rate of native-born foreigners relative to native Germans in the age group 25-34 years, by gender

\begin{tabular}{llll}
\hline & 1992 & 1999 & 2004 \\
\hline Women & 0.84 & 0.85 & 0.76 \\
Men & 0.94 & 0.92 & 0.88 \\
\hline
\end{tabular}

Source: Liebig 2004, Table 5b

\section{Differences in sectors of employment}

Generally speaking, migrant and ethnic minority workers are employed in different segments of the labour market than native workers. Among migrant and ethnic minority workers, however, there is a distinction between employees from Western Europe and third-country nationals. Western European immigrants are often highly mobile financial and technical professionals who earn a great deal of money, while the majority of third-country nationals are employed in lowskilled, low-paid professions. Migrant and ethnic minority workers are disproportionately employed in the so-called $3 \mathrm{D}$ jobs: dirty, dangerous and demanding, and they are more likely to hold precarious positions (more fixed-term and flexible labour contracts). Furthermore, they are heavily concentrated in certain industrial sectors (e.g. manufacturing, construction), parts of the service sector (e.g. personal services, cleaning, catering, caring) and sectors that are subject to strong seasonal fluctuations (e.g. tourism and agriculture). This is partly a result of the recruitment of low-skilled migrant workers in particular industries and occupations, especially during the I96os and I970s. Consequently, migrant workers have been particularly affected by technological change and industrial restructuring, as the demand for low-skilled jobs has di- 
minished. At the same time, the shift to employment in the service sector often creates specific problems for immigrant workers, as the newly created jobs in this sector often require particular skills (EUMC 2003: 35).

There are also noticeable gender differences in relation to sectors of industry and occupations. Though not adequately acknowledged, migrant and ethnic minority women have participated in European labour markets since the Second World War. They initially worked in factories and as cleaners, care and nursing assistants in residential homes and hospitals (Kofman et al. 2000; Knocke 2005). Some came as labour migrants from Mediterranean countries and former European colonies to Northern Europe, and many entered through family reunification as mass labour migration ended in the mid-I970s. While women who entered through family reunification were usually treated as dependants and initially faced restrictions on entry into the labour market in some countries, they too became part of the labour force.

In the early years of immigration, migrant women were overrepresented in the less-skilled occupations, such as domestic work and in hotels and restaurants. At that time, however, there was a smaller gap between migrant and native women (Dumont \& Liebig 2005). By the mid-I990s, independent female labour migration was growing. But while native women have moved into higher-skilled occupations, this has not generally been the case for migrant women, especially in Southern Europe, where the shortfall of child and elderly care provision by the welfare state opened up a major sector of household employment. Nonetheless, quotas for this sector have been inadequate, forcing many migrant women to work with an irregular status.

The use of networks and contacts to obtain employment frequently reinforces gender and ethnic segregation, as do stereotyping by employers and institutional discrimination (McIlwaine et al. 2006; Rydgren 2004). In many countries, women with a migrant background are still often concentrated in certain segments of the labour market, such as personal and domestic services, cleaning, catering, health and child and elderly care (EUMC 2003: 5; Dumont \& Liebig 2005). ${ }^{2}$ Domestic services, cleaning and catering are highly unregulated segments of the labour market and are often unprotected by collective bargaining agreements, which gives these women less access to benefits such as training, health insurance, paid or unpaid sick leave, maternity leave, employment protection and other social rights.

There is evidence of great differences between ethnic groups in relation to sectoral segregation: For example, the EOC's 2007 investigation found that in the UK 46 per cent of the employed Black Caribbean women work in the public sector compared to an average of 34 per cent of all women and 16 per cent of all men. ${ }^{3}$ 
With the exception of the UK and Portugal, the difficulty of getting qualifications recognised and the impossibility of obtaining regulated professions and public sector employment in the EU have resulted in a pattern of high concentration in a few sectors and very low proportions in skilled occupations (Dumont \& Liebig 2005). The UK is the only country where the share of low-skilled women has sharply declined and a higher proportion of foreign-born women, including from nonOECD countries, are employed in highly-skilled occupations. The UK is also characterised by a relatively low percentage difference of overqualified foreign-born women compared to native-born women. It is also the only country to have a significant number of migrant women in the traditionally male IT sector (I.5 per cent). Education, health and other social and community services are also significant sectors of employment, though not as high as in Scandinavian countries such as Norway and Sweden (SOPEMI 2006).

Table 3.5 Female employment by sector and birth status

\begin{tabular}{|c|c|c|c|c|}
\hline \multirow[t]{2}{*}{ Economic sector } & \multicolumn{2}{|c|}{ Foreign-born women } & \multicolumn{2}{|l|}{ Native-born women } \\
\hline & $\begin{array}{l}\text { Foreign-born } \\
\text { women's share } \\
\text { of total } \\
\text { employment (\%) }\end{array}$ & Overrepresented & $\begin{array}{l}\text { Native-born } \\
\text { women's share } \\
\text { of total } \\
\text { employment (\%) }\end{array}$ & Overrepresented \\
\hline Agriculture and fishing & 1.1 & No & 3.3 & No \\
\hline $\begin{array}{l}\text { Mining, manufacturing and } \\
\text { energy }\end{array}$ & 12.1 & No & 12.8 & No \\
\hline Construction & 1.0 & No & 1.5 & No \\
\hline Wholesale and retail trade & 12.6 & Ind. & 15.6 & Yes \\
\hline Hotels and restaurants & 8.1 & Yes & 4.4 & Yes \\
\hline Education & 8.1 & Yes & 11.2 & Yes \\
\hline $\begin{array}{l}\text { Health and other community } \\
\text { services }\end{array}$ & 17.0 & Yes & 16.5 & Yes \\
\hline Households & 6.2 & Yes & 1.6 & Yes \\
\hline Administration and ETO & 4.7 & No & 7.5 & Ind. \\
\hline Other services & 23.2 & Ind. & 21.2 & Ind. \\
\hline
\end{tabular}

Notes: Columns do not sum to 100 because not all employed women indicate their sector of activity. Overrepresentation occurs when the share of foreign-born or native-born women in one particular sector is more important than their share in total employment. Sector overrepresentation is said to be undetermined (Ind.) if the share of foreign-born or nativeborn women in a given sector divided by their share in total employment is higher than 0.9 and lower than 1.1.

Source: European Community Labour Force Survey (data provided by Eurostat) 
Table 3.6 Employment of women in selected countries

\begin{tabular}{|c|c|c|c|c|}
\hline & \multicolumn{2}{|l|}{1994} & \multicolumn{2}{|l|}{2004} \\
\hline & $\begin{array}{l}\text { Foreigners } \\
\%\end{array}$ & $\begin{array}{l}\text { Natives } \\
\%\end{array}$ & $\begin{array}{l}\text { Foreigners } \\
\%\end{array}$ & $\begin{array}{l}\text { Natives } \\
\%\end{array}$ \\
\hline \multicolumn{5}{|c|}{ Household services } \\
\hline Spain & 27.1 & 6.9 & 36.0 & 4.6 \\
\hline France & 14.7 & 3.5 & 21.1 & 3.8 \\
\hline Greece & 35.0 & 1.5 & 42.4 & 1.3 \\
\hline Italy & 10.3 & 2.3 & 27.9 & 1.6 \\
\hline UK & 3.7 & 1.1 & 3.1 & 0.8 \\
\hline \multicolumn{5}{|c|}{ Hotels and Restaurants } \\
\hline Germany & 10.8 & 3.2 & 11.5 & 3.8 \\
\hline Spain & 24.4 & 7.1 & 19.0 & 7.5 \\
\hline France & 8.5 & 3.8 & 6.0 & 3.4 \\
\hline Greece & 12.2 & 6.4 & 16.3 & 7.4 \\
\hline UK & 6.5 & 5.7 & 7.6 & 5.2 \\
\hline \multicolumn{5}{|c|}{ Health and Social Services } \\
\hline Belgium & 14.5 & 19.3 & 15.9 & 22.4 \\
\hline Germany & 11.9 & 11.7 & 15.7 & 19.6 \\
\hline Denmark & 37.6 & 26.9 & 27.4 & 32.6 \\
\hline France & 10.5 & 16.9 & 12.1 & 20.3 \\
\hline UK & 21.0 & 18.8 & 25.0 & 20.6 \\
\hline \multicolumn{5}{|l|}{ Education } \\
\hline Belgium & 6.8 & 15.3 & 7.5 & 14.8 \\
\hline Germany & 3.4 & 7.9 & 5.7 & 8.8 \\
\hline Spain & 9.5 & 9.8 & 3.8 & 10.2 \\
\hline France & 4.8 & 11.3 & 6.8 & 10.5 \\
\hline Italy & 16.1 & 14.8 & 4.2 & 14.0 \\
\hline UK & 12.5 & 11.4 & 11.4 & 14.4 \\
\hline \multicolumn{5}{|c|}{ Information Technology } \\
\hline UK & unavailable & unavailable & 1.5 & 0.8 \\
\hline
\end{tabular}

Source: European Community Labour Force Survey

\section{Income, working conditions and terms of employment}

Generally speaking, income differences between native and migrant workers can be observed in all EU member states. Even though there is a lack of data on the specific incomes of migrants, what we do know indicates a sharp difference between EU nationals and non-nationals, which corresponds to differences in occupation, length of stay and legal status (Ayres \& Barber 2006). Adsera and Chiswick (2004) carried out an analysis of earnings of immigrants compared to native-born workers in various European countries. In their sample, earnings of immigrants upon arrival were found to be on average 38 per cent lower for women and 42 per cent lower for men. For example, earnings of foreign women in Germany were found to be 8 per cent lower than those of native-born women, while in Sweden they were 62 per cent 
lower than for native-born women. Major differences were also found in Finland, Luxembourg and Italy.

For migrant women, low pay results from overrepresentation in marginal and flexible sectors, such as cleaning and domestic work, with poor protection and working conditions (see Table 6). The European Trade Union Confederation has highlighted the need to organise domestic work and provide those in need with appropriate services and support (ETUC 2005).

Due in part to the characteristics of the sectors they work in, migrant women are also more likely to have temporary work contracts (Table 7), a pattern that is particularly evident in Southern European countries. In Sweden too, complaints were voiced about temporary work that does not allow women to plan ahead (Cederberg 2007). These employment characteristics may contribute to their taking a much longer time than men to achieve a level commensurate with their qualifications.

Table 3.7 Share of women with temporary contracts, 2004 (aged 15-64)

\begin{tabular}{lcc}
\hline & Temporary \% & \\
\cline { 2 - 3 } Country & Foreign-born & Native-born \\
\hline Austria & 9.0 & 8.6 \\
Belgium & 14.7 & 11.2 \\
France & 14.7 & 13.6 \\
Germany & 13.7 & 12.1 \\
Greece & 24.7 & 13.3 \\
Ireland & 5.4 & 3.7 \\
Italy & 16.9 & 14.8 \\
The Netherlands & 20.8 & 15.4 \\
Portugal & 28.2 & 20.5 \\
Spain & 53.1 & 31.8 \\
Sweden & 22.9 & 16.7 \\
UK & 10.6 & 5.7 \\
\hline
\end{tabular}

Source: European Labour Force

A survey of immigrants conducted in the south of Italy in 2003 revealed 24 per cent of women were unhappy with their working conditions and 33 per cent experienced discrimination in terms of pay, treatment, tasks assigned to them and hours worked (Chaloff 2005).

Inferior working conditions are not only found in poorly protected occupational sectors. Even in public sectors such as health services, migrant and minority women tend to have an inferior position compared to native women. For example, nurses from minority ethnic origins in the UK are more likely than white nurses to work longer hours, be forced to take on additional jobs, have experienced bullying or harass- 
ment on the job and have changed jobs due to negative pressure (RCN 2002: 85).

In the Dutch health sector, ethnic minority and indigenous women tend to differ in the types of jobs and contracts they have. Ethnic minority women are more often employed in lower, auxiliary positions and less often on the executive level. They are also more likely to have temporary contracts than their indigenous counterparts, and are over four times more likely to have a subsidised job intended for the long-term unemployed.

In Ireland, Filipino women working in nursing and health care have fewer employment rights than their Irish counterparts and are overcharged for the overcrowded accommodations provided to them. They also experience excessive deductions from their wage packets and nonrecognition of their qualifications (EUMC, 2003: 47).

\section{Deskilling and underutilisation of skills and educational qualifications}

Migrant women not only experience the same difficulties faced by migrant men, such as lack of domestic labour market experience and human capital, language problems, lack of recognition of qualifications and discrimination, but also gender-specific problems such as lower appreciation of their capital (Dumont \& Liebig 2005) and social competence (Knocke 2005). While deskilling is particularly severe in Greece and Spain, it is also considerable in many other countries such as Finland, Germany and Ireland (SOPEMI 2006). As Wall et al. report, there are many practical problems with the recognition of migrants' qualifications and professional skills (Wall et al. 2005). In addition, some skills may not be easily transferable (Dustman \& Schmidt 2000). Therefore, many migrants end up working in jobs for which they are overqualified, due in part to non-recognition of qualifications as well as ethnic and racial discrimination (McIlwaine et al. 2006). This is even more common for women from non-OECD member countries, especially in Germany, Switzerland, Luxembourg and the Nordic countries (Dumont \& Liebig 2005). Furthermore, having higher educational qualifications brings migrant women fewer rewards than female nationals. This outcome most likely reflects problems arising from the recognition of qualification in highly regulated education and health sectors, in which many skilled migrant women are concentrated (Kofman 2007; SOPEMI 2006). For example, the British National Health Service (NHS) has clearly defined opportunities for career progression and different pay grades that can act as a promotion incentive. 70 per cent of the Afro-Caribbean nurses say they are inappropriately graded, com- 
pared to 5I per cent of the white nurses (RNC 2002: 52.). There are numerous problems in career progression, though, as black ethnic minorities take five years longer than white Britons, especially to reach management levels, and men tend to progress much more quickly than women. It has been stated that roughly two-thirds of the managers in the NHS are female (Truss \& O'Callaghan I998: 2). Nonetheless, among the most senior civil servants (including NHS managers), just I8 per cent are women, against a target of 25 per cent (Butler 200I). For ethnic minorities, the situation is even worse. Although 45 per cent of the hospitals state they have black, Asian or ethnic personnel in senior management positions just below board level, this figure decreases to 22 per cent for executive board positions, and only 3 per cent of the senior managers are from ethnic minority backgrounds (Agnew 2000). Therefore, in most member states, migrant and ethnic minority women are more often employed in jobs below their educational qualifications (see Table 8).

Table 3.8 Percentage of women by birth status (15-64) in jobs for which they are overqualified, 2003-2004

\begin{tabular}{lrcc}
\hline Country & Native-born & Foreign-born & $\begin{array}{c}\text { Foreign-born } \\
\text { non-OECD }\end{array}$ \\
\hline Austria & & & 32.8 \\
Belgium & 9.3 & 24.8 & 27.2 \\
Czech Republic & 17.7 & 24.6 & 22.0 \\
Denmark & 6.6 & 12.8 & 31.0 \\
Finland & 10.5 & 19.7 & 38.0 \\
France & 18.8 & 26.2 & 19.8 \\
Germany & 14.2 & 18.8 & 32.3 \\
Greece & 9.9 & 23.6 & 62.0 \\
Hungary & 9.0 & 53.4 & 8.9 \\
Ireland & 7.3 & 10.5 & 38.2 \\
Italy & 15.6 & 23.9 & 34.0 \\
Luxembourg & 7.1 & 27.4 & 31.0 \\
Norway & 3.2 & 14.1 & 35.9 \\
Portugal & 10.6 & 25.1 & 18.7 \\
Spain & 8.9 & 16.2 & 56.7 \\
Sweden & 24.4 & 47.6 & 23.2 \\
Switzerland & 7.2 & 15.3 & 19.8 \\
UK & 7.6 & 13.8 & 18.7 \\
\hline
\end{tabular}

Source: SOPEMI 2006, Table I.16

The evidence presented in Table 8 of unequal labour market outcomes across Europe fails to show differences within countries between nationalities, ethnicities, established and recent migrants and routes of entry. For example, recent research in the UK has highlighted the con- 
siderable differences between women of different ethnicities in terms of labour force participation, over-qualification and ideologies of motherhood (Dale et al. 2006; Dex \& Lindley 2007). Over-qualification was found to be highest among Sub-Saharan African and Chinese women. Black Caribbean women tended to have an even stronger attachment to the labour market than white women and than Black Caribbean men. On the other hand, low rates of labour force participation and post-secondary education characterise Pakistani and Bangladeshi women, for whom motherhood was associated with full-time care for children. Even among educated women in the latter groups, there was a much greater tendency to leave the labour market while children were young. Such a pattern cannot be solely imputed to religion and culture. Social origin and class in the homeland and the fact that these groups are the most disadvantaged are factors that must be taken into account. In this context, the pressure for women to nurture their young and preserve the honour of their community is heightened.

In other European countries, there are substantial variations in labour force participation, educational achievement and access to more skilled occupations. Very low levels of education are to be found among Turkish and Moroccan women in the Netherlands. For example, 5I per cent of Turkish women had only primary education (or not even that), compared to 40 per cent of Turkish men (Keuzenkamp \& Merens 2007).

\section{Immigration, legal status and employment}

A dimension that has not been taken into account in most national studies on labour market participation and integration is immigration regulations and legal status. Many of the inequalities discussed above are shaped and/or reinforced by legally sanctioned discrimination arising from the application of immigration regulations and conditions. A tension increasingly exists between immigration policies and labour market demands. While immigration policies have become more selective in favouring skilled workers, they have restricted entry for less skilled non-EU workers, probably resulting in higher levels of undocumented workers who do not have access to antidiscrimination legislation. The ability to access and use legislation to pursue and enforce rights varies markedly by legal status.

Country policies on immigration, residence, employment and citizenship play a major role in the workforce position of migrant and minority ethnic populations. While minority ethnic citizens including naturalised migrants may not encounter legal discrimination, many non-EU citizens who have full rights to residency and work suffer not 
only informal racial discrimination, but also formal legal discrimination excluding them from certain forms of employment. This applies particularly to the public sector, which in many states is largely closed to them. Third country-nationals 'whose employment is constrained by revocable work or residence permits only for a fixed period' may confront more restrictive conditions of employment and exploitation, as well as formal and informal discrimination. Undocumented migrants, including asylum seekers, are officially barred from the labour market. Recent migrants are particularly affected by restrictive conditions. Article I3 of the Treaty of Amsterdam prohibited discrimination based on sex, racial or ethnic origin, religion or belief, disability, age or sexual orientation, but not aspects concerning legal and immigration status. The different legal statuses have implications for the type of work migrants can do compared to citizens. The following typology of legal status modifies and updates that of Wrench (Wrench 2007: 69-70):

I. Citizens living and working within their own country of citizenship. This includes people of immigrant origin who have become naturalised and citizens of the original fifteen member states of the European Union. All occupations are open to them.

2. EU nationals from the A8 accession countries who are allowed entry into certain countries (originally Ireland, Sweden and the UK) and are eligible for public sector and other forms of protected employment in certain EU-I5 states, but not in others. Even in countries where there are no restrictions on their employment, such as in the UK, the vast majority are employed in less skilled work reflecting the typical gender division of labour (for example, female migrants in child and elderly care) (Home Office et al. 2007). An increasing number of states, especially in Southern Europe, have opened up their borders, while others such as Belgium, France and the Netherlands have lifted restrictions in designated sectors since 2006 (Chow et al. 2006).

3. Third-country nationals who have full rights to residency and work in a member state (non-EU citizens). They are excluded from a whole range of public sector occupations, the extent of which varies between states. In many countries like France, Germany and Italy, a very wide range of occupations in administration, education and health are not open to them.

4. Third-country nationals whose employment in the country is constrained by a revocable work or residence permit, often for a fixed period of time. Those entering through family reunification streams may be given limited residence permits and are generally subject to a probationary period (see below). 
5. Undocumented workers including asylum seekers, overstayers and those who have entered illegally while they are waiting for a decision, or asylum seekers who have been denied residency and are not permitted to work. Excluding asylum seekers from work became the norm in France in I99I and in the UK in 2002. Sweden is one of the few countries not to exclude asylum seekers from working.

In addition, immigration regulations have implications for gender, which we can see for example in relation to quotas for certain sectors that are either largely occupied by men, such as construction, or filled by women, such as domestic labour and care. The quotas in the latter case may be insufficient due to the undervaluing of this form of labour, thus forcing many women to work illegally. Amnesties and regulations for contract work in Italy have tended to favour sectors employing mostly men, with domestic-related work as the only exception (Chaloff 2005). In many countries, household labour, though in growing demand, is either not recognised for purposes of work permits or has lesser rights attached to it. It has been noted that domestic workers experience a degree of vulnerability that is unparalleled to that of other workers' (ILO 200I cited in European Women's Lobby 2007:29).

Other regulations may seem gender-neutral, but in effect include criteria such as previous earnings, which tend to favour men. An example of this is the Highly Skilled Migrants Programme in the UK, in which men predominate (Kofman et al. 2005). For female migrants who enter disproportionately through family reunification, the conditions of immigration are particularly salient. In general, family migrants are assumed to be not primarily concerned with the labour market. Until recently, some countries prohibited these individuals from entering the workforce in their early years of settlement. Such exclusions are likely to have played a part in the low level of labour force participation among female migrants from Muslim countries.

\section{Route of entry}

The route of entry is also important, especially for non-EU female migrants. While independent female labour migration has increased markedly in the past decade, the vast majority of migrants enter many EU countries through family streams (Kofman 2004). Many of these women may not have initially been eligible to work. The European Directive 2003/86/EC (on the Right to Family Reunification) states that although family members must be given access to employment and vocational training, countries may still include considerations of the labour market situation in determining whether the family member is 
able to enter employment or engage in self-employment. Since women make up the majority of family reunification migrants, such restrictions have tended to affect them much more than men. In a number of EU countries, family migrants were denied work permits especially during their initial years of settlement, this due to the prevailing situation of the labour market. Such restrictions were considered to be a major reason for low participation in the labour market among Turkish women in Germany (Liebig 2007). Women in Portugal who enter through family reunification are not allowed to work automatically but require a permit, which usually takes more than three months to obtain, and for which a work contract is required in order to apply (Wall et al. 2005: 3). These kinds of practices prolong the time they are unemployed, and make it very difficult to find employment in the end.

Table 3.9 Family and long-term migrants (absolute numbers), and the proportion of family migrants among long-term migrants (\%), 2004

\begin{tabular}{lccc}
\hline Country & $\begin{array}{c}\text { Family migrants } \\
(* 1,000=a b s .)\end{array}$ & $\begin{array}{c}\text { Long-term migrants } \\
(* 1,000=a b s)\end{array}$ & \% family \\
\hline Austria & 34.4 & 54.2 & 63.5 \\
France & 112.6 & 175.2 & 64.3 \\
Germany & 90.4 & 202.2 & 44.7 \\
Italy & 96.5 & 156.4 & 61.7 \\
The Netherlands & 28.4 & 57.0 & 49.4 \\
Norway & 12.6 & 21.4 & 59.9 \\
Portugal & 4.7 & 13.0 & 36.2 \\
Sweden & 27.6 & 40.7 & 67.8 \\
Switzerland & 38.8 & 82.6 & 47.0 \\
UK & 100.8 & 266.4 & 37.8 \\
\hline
\end{tabular}

Note: In this table, family migrants include family members of economic and work permit migrants, but not those entering through humanitarian channels or those entering through family streams.

Source: SOPEMI 2006

Women who migrated after marriage were also less likely to be actively employed than unmarried migrant women (Duleep \& Sanders 1993). Moreover, the longer the husbands stayed in the country and increased their chances of accumulating financial resources, the less likely their wives were going to participate in the labour market. Due to financial constraints, migrant women may have limited access to child care and lack family or social support networks enabling them to make private arrangements (Dumont \& Liebig 2005). The lack of affordable child care may determine migrant women's labour force participation, so that women who delay entering the workforce for this reason can face difficulties when they try to do so later (Heron 2005). In the UK, the 
recent subsidisation of child care has taken the form of tax credits for which non-EU migrants cannot apply during the first five years. In other words, they have no recourse to public funding.

\section{Duration of residence}

For some migrant women, length of stay helps them to overcome the initial handicap, but it does not do so to the same extent as for migrant men (Dumont \& Isoppo 2005). This situation is more evident for migrant women in most EU countries, especially where family migration is high, such as France and Sweden. On the other hand, it is less evident where they have largely entered as labour migrants, such as in Southern and Central Europe and Ireland. Still, over time and for all types of migration, migrant men's convergence in relation to employment rates of non-migrant men are achieved after six years of residence, whereas women do not even manage to achieve convergence after ten years (Dumont \& Liebig 2005).

The difficulty of overcoming initial disadvantages and barriers can be caused by several factors. First of all, it may involve profound protectionism and closure of certain kinds of labour markets such as the civil service. In all likelihood, difficulties also involve strong gender stereotyping and the channelling of women into certain forms of 'female' employment, from which it is difficult to escape. Secondly, it may stem from the differential routes of entry, in particular the high proportion of women who enter through family reunification and subsequently face restrictions on their entry into the labour force, at least during the initial years of residence. Thirdly, the 'time gap' - in which women spend more time in unpaid care for dependents and those with special needs than men, which results in unequal opportunities to enter the labour market and to obtain a full-time job - can impact their labour market participation and income. Many migrant and ethnic minority women are affected by this time gap and balancing of work and family life to a greater extent than native women. This is because they have larger (extended) families and more family responsibilities (i.e. taking care of the elderly), and/or are more likely to be single parents (EOC 2007: 28).

\section{Conclusions}

Though the experiences of migrant and ethnic minority women in the EU are heterogeneous, evidence suggests they experience multiple forms of inequality that reflect the complexity of their identity as women and as migrants. These different forms of unequal opportunities 
may reinforce and interact with each other. Irrespective of their educational level or skills, migrant women might be employed in low-status sectors because of their migrant or ethnic status, and in low-paid sectors that typify the gender gap in pay. There may be little choice of occupation due to stereotyping and discrimination in which characteristics of docility and aptitude for certain tasks are imputed to migrant and ethnic minority women. Hence, migrant and ethnic minority women not only suffer from an ethnic penalty, but also from gender-specific difficulties such as lower appreciation of their capital.

In this chapter, we have shown that as far as issues such as employment and unemployment rates, labour market segmentation, working conditions and terms of employment are concerned, migrant and ethnic minority women have on average an inferior position compared to both native men and women and migrant men in virtually all EU member states. They tend to be clustered in the less skilled occupations, and are often overqualified for the type of jobs they undertake. Highly qualified women from non-OECD countries are particularly disadvantaged. While partly offsetting the initial handicap, longer duration in the receiving country does not greatly improve the employment situation in some countries. Although there is scarce data available on the offspring of migrants, there are signs of progress over generations. In the Dutch case, for example, second-generation Turkish and Moroccan women have higher participation rates than the first generation. Nevertheless, the labour market outcomes of the second generation lag behind those of their native peers, even when they have reached a comparable educational level.

These inequalities could partially be explained by differences in supply-side factors such as skill level and educational qualifications, human capital, vocational preferences or job-seeking activities. More traditional gender role attitudes among certain groups of migrants (e.g. Muslims) are significant as well. But analysis of recent statistical data, which controlled for other variables, indicates that discrimination may also play a part in the differences between migrant and ethnic minority women and their native counterparts. For example, the employment gap between migrant and ethnic minority women and native women tends to widen as a function of the level of education, which suggests that qualifications are not being recognised and human capital is not being transferred. Language difficulties are only one aspect of the problem of human capital transference. Generally speaking, foreign women are overrepresented at the top and bottom levels of education. In the new countries of immigration such as Ireland, Greece, Spain and Portugal, foreign women tend to be better qualified than native women but still work in low-status jobs (Dumont \& Isoppo 2005). 
Several of these aspects warrant further discussion to understand the differences in labour market outcomes between native and migrant women, and the ways in which formal and informal discriminatory practices may be contributing to these differences. We are beginning to paint a cross-national picture on gender and ethnic inequalities in labour market outcomes. This picture covers rates of participation, unemployment and level of over-qualification, but there is still a rudimentary understanding of how different forms of discrimination interact with socioeconomic characteristics, and how this varies per country and by nationality/ethnicity at different stages of the life cycle and in the workplace. This will require more penetrating analyses of quantitative and qualitative data in different countries. Nonetheless, the current statistical infrastructure has a number of shortcomings. The data on the labour market participation of ethnic minorities often pays only minor attention to gender differences, and the data on the gender aspect of labour differences gets little attention. Furthermore, surveys are usually not translated in other languages, which hampers the participation of migrants and ethnic minorities who have not mastered the local language. Other crucial shortcomings are that data only includes nationality and is restricted to the first generation, or considers the first and second generation as one group. This hinders the effective monitoring of developments in the labour market position of ethnic minority groups.

\section{Notes}

I This chapter was first published as a state-of-the-art report on gender written by Eleonore Kofman (Social Policy Research Centre, Middlesex University) with Bernadetta Siara (Westminster University), Floya Anthias and Maja Cederberg (FEMIPOL Project, Oxford Brookes University). The state-of-the-art report has been thoroughly rewritten and extended for this volume by Judith Roosblad and Saskia Keuzenkamp.

2 See also Tables 5 and 6.

3 EOC, 2007: I8.

\section{References}

Adsera, A. \& B. R. Chiswick (2004), Are There Gender and Country of Origin Differences in Immigrant Labor Market Outcomes across European Destinations? Bonn: IZA.

Agnew, T. (2000), Down Equality Street. Emap Public Sector Management

Ayres, R. \& T. Barber (2006), 'Statistical analysis of female migration and labour market integration in the EU', FeMiPol Working Paper No. 3. Oxford: FeMiPol.

Butler, P. (200I), 'Top of the NHS is no place for women', in The Guardian, I6 April $200 \mathrm{I}$.

Cederberg, M. (2007), 'State of the Art Theoretical Perspectives and Debates in Sweden', FeMiPol Working Paper No. 4. Oxford: FeMiPol. 
Chaloff, J. (2005), 'Immigrant Women in Italy', in Migrant Women and the Labour Market: Diversity and Challenges. Brussels: OECD and European Commission.

Chow, K., T. Venables \& M. Bryska (2006), 'Report on the Free Movement of Workers in EU-25. The Functioning Arrangements - Two Years after Enlargement'. Brussels: European Citizen Action Service.

COM (2004), First Annual Report on Migration and Integration. Brussels: Commission of the European Communities.

Dale, A., J. Lindley \& S. Dex (2006), 'A life course perspective on ethnic minority differences in women's economic activity in Britain', European Sociological Review 22 (4): 459-76.

Dex, S. \& J. Lindley (2007), 'Labour market job matching for UK minority ethnic groups', GeNet Working Paper 23.

Duleep, H. O. \& S. Sanders (I993), 'The Decision to Work by Married Immigrant Women', Industrial and Labor Relations Review 46 (4): 677-690.

Dumont, J. C. \& T. Liebig (2005), 'Labour Market Integration of Immigrant Women. Overview and Recent Trends', in Migrant Women and the Labour Market: Diversity and Challenges. Brussels: OECD and European Commission.

Dumont, J. C. \& M. Isoppo (2005), 'The participation of immigrant women in the labour market: a double handicap despite the progress made', in Migrant Women and the Labour Market: Diversity and Challenges. Brussels: OECD and European Commission.

Dustmann, C. \& C. Schmidt (2000), The Wage Performance of Immigrant Women: Fulltime Jobs, Part-time Jobs, and the Role of Selection. London: Centre for Economic Policy Research.

Equal Opportunities Commission (EOC) (2007), Moving on up? The way forward. Report of the EOC's investigation into Bangladeshi, Pakistani and Black Caribbean women and work.

European Commission (2008), Equality between Women and Men. Luxembourg: Office for Official Publications of the European Communities.

EUMC (2003), Migrants, Minorities, and employment: Exclusion, Discrimination and Antidiscrimination in 15 Member States of the European Union, EUMC: Vienna.

European Trade Union Confederation (2005), Out of the shadows. Organising and protecting domestic workers in Europe - the role of trade unions. Brussels: ETUC.

European Women's Lobby (2007), 'Equal Rights, Equal Voices: Migrant Women in the European Union', Brussels, I9-2I January 2007.

Heron, A. (2005), 'Migrant Women into Work - What is Working?', in Migrant Women and the Labour Market: diversity and challenges. Brussels: OECD and European Commission.

Home Office, Department for Work and Pensions, HM Revenue \& Customs and Communities and Local Government (2007), Accession Monitoring Report, May 2004-December 2006, no. IO, London.

Keuzenkamp, S. \& A. Merens (2007), 'De positie van allochtone meisjes en vrouwen', in J. Dagevos \& M. Gijsberts (eds.), Jaarrapport Integratie 2007, 249-28I. The Hague: Sociaal en Cultureel Planbureau.

Knocke W. (2005), Immigrant Women on the Swedish Labour Market - The Past and Present Situation, in Migrant Women and the Labour Market: Diversity and Challenges. Brussels: OECD and European Commission.

Kofman, E. (2004), 'Family-related migration: a critical review of European studies' Journal of Ethnic and Migration Studies 30 (2): 243-262.

Kofman, E. (2007), 'Gendered migrations, livelihoods and entitlements in European welfare states', in N. Piper (ed.), New Perspectives on Gender and Migration: Empowerment, Rights, and Entitlements, 59-IOI. New York: Routledge. 
Kofman, E., P. Raghuram \& M. Merefield (2005), Gendered Migrations: towards gender sensitive policies in the UK, Asylum and Migration Working Paper 6, Institute of Public Policy Research.

Kofman, E., A. Phizacklea, P. Raghuram \& R. Sales (2000), Gender and International Migration in Europe: employment, welfare and politics. New York: Routledge.

Liebig, T. (2007), The Labour Market Integration of Immigrants in Germany. OECD Social, Employment and Migration Working Paper 47.

McCall, L. (2005), 'The complexity of intersectionality', in Signs. Journal of Women in Culture and Society 30 (3): I77I-I800.

McIlwaine C., K. Datta, Y. Evans, J. Herbert, J. May \& J. Wills (2006), Gender and Ethnic Identities among Low-Paid Migrant Workers in London. London: Queen Mary, University of London.

Merens, A. (2006), 'Betaalde arbeid' in S. Keuzenkamp \& A. Merens (eds.), Sociale atlas van vrouwen uit etnische minderheden, 68-90. The Hague: Sociaal en Cultureel Planbureau.

OECD (2008), Jobs for Immigrants (Vol. 2): Labour market integration in Belgium, France, The Netherlands and Portugal. Paris: OECD.

OECD/European Commission (2005), Migrant Women and the Labour Market: Diversity and Challenges.

Royal College of Nursing (RCN) (2002), Valued equally? www.rcn.org.uk.

Rydgren, J. (2004), 'Mechanisms of exclusion: ethnic discrimination in the Swedish labour market', Journal of Ethnic and Migration Studies 30 (4): 697-716.

SOPEMI (2006), International Migration Outlook. Paris: OECD.

Truss, C. \& F. O'Callaghan (I998), 'Experience of Management Careers in the NHS', Research Paper in Human Resource Management, Kingston Business School.

Tubergen, F. van (2005), The Integration of Immigrants in a Cross-national Perspective: Origin, Destination, and Community Effects. Utrecht: Utrecht University.

Tubergen, F. van \& I. Maas (2004), Women migrants in the European Union. A Demographic and Socioeconomic Profile. Den Haag: SZW.

Verloo, M. (2006), 'Multiple Inequalities, Intersectionality and the European Union', European Journal of Women's Studies I3 (3): 2II-228.

Wall, K., C. Nunes \& A. R. Matias (2005), 'Female Migration Vision. Immigrant Women in Portugal: Migration Trajectories, Main Problems and Policies', Working Papers. Lisbon: Instituto de Ciencias Sociais.

Wrench, J. (2007), Diversity management and discrimination. Immigrants and ethnic minorities in the EU. Aldershot: Ashgate.

Zorlu, A. (200I), Do ethnicity and sex matter in pay and employment choices? Analysis of 8 groups in the Dutch labour market. Amsterdam: University of Amsterdam Press. 


\title{
4 Employment equity policies in work organisations
}

\author{
Stijn Verbeek and Rinus Penninx
}

\section{Introduction}

The preceding chapters have focused on the labour market situation of immigrants and ethnic minorities, as well as the mechanisms and various forms of discrimination that influence this labour market outcome, including the role of gender. In principle, two lines of reasoning have been used to analyse the relation between discrimination of immigrants or ethnic groups and inequality. The first starts from evidence of inequality at the group level and analyses to which extent that inequality can be attributed to discriminatory processes by checking for relevant factors that may account for differences between groups. The second outlines evidence of research on discrimination in its different forms from which inequality at the group level has been the consequence.

In this chapter, we will take a different perspective and move from describing labour market opportunities and analysing factors that negatively influence these opportunities to an analysis of the policies that are being developed to combat discriminatory practices and resulting inequality.

Policies aim at a desired outcome - in our case, 'employment equity'. Equity is defined here as a non-discriminatory outcome in terms of 'ethnicity' or 'immigrant background'. Therefore, employment equity policies (EEPs) are specific policy tools that are designed to strive for employment equity. Such EEPs basically exist in two forms: direct and indirect. With direct EEPs, organisations aim at employment equity in their own workforce, whereas indirect EEPs are formulated to convince or pressure other organisations to strive for employment equity. Governments may use both forms of EEPs, partly to set an example to be followed by society at large (Bovenkerk 1986; Dagevos \& Beljaarts I996). In other words, governmental organisations try to improve the position of ethnic minorities in their own workforces (direct EEPs) and try to persuade other work organisations to do the same (indirect EEPs). Indirect EEPs are found less among non-governmental work organisations, such as companies ${ }^{\mathrm{I}}$ and NGOs. ${ }^{2}$ 
This chapter focuses on direct EEPs, which is a consequence of the focus of this publication and the workshops on which it is based. These workshops aimed primarily at trade unions, employers' associations and large companies as stakeholders that should be informed about the state of research in this field. The literature on indirect EEPs is of course also very interesting. There is a significant tradition of such policies in the US under the name of affirmative action (Agocs \& Burr I996; Appelt \& Jarosch 2000; Bovenkerk 1986; Glazer I987, 2000; Holzer \& Neumark 2000; Kelly \& Dobbin I998; Leonard 1990; Skrentny 1996), in Canada under various names (Abella I984, I985; Adams et al. I995; Agocs 2002; Jain \& Lawler 2004; Kurthen I997; Mentzer \& Fizel I992; Ventura 2000) and elsewhere around the world (Jain et al. 2003; Sowell 2004; Thomas 2002; Verhoeven \& Martens 2002). In Europe, the UK has built up a tradition under the term positive action (Kirton \& Greene 2005; Moore 1997; Sloane \& Mackay I997; Taylor 2000; Wrench \& Modood 2000). In continental Europe, however, such governmental initiatives have been largely absent ${ }^{3}$, except in the cases of Sweden (Soininen \& Graham 2000) and the Netherlands, where they were part of early integration policies for immigrants (Abell et al. 1995; Bacchi 1994; Glastra et al. I998; Gras \& Bovenkerk I995; Jonkers 2003; Smeets I993). Even a first glance at this literature on indirect EEPs shows that the variation is great and that such policies and programmes are still hot topics for both politicians and researchers. One of the most important issues in this regard is the level of pressure put on work organisations: both when it concerns the actual implementation of relevant laws and the actual content of employment equity goals to be pursued by work organisations.

In our analysis of direct EEPs, we will start off by briefly introducing some crucial concepts behind these programmes. ${ }^{4}$ The next step is to outline their scope by describing the various elements and instruments that may be part of them. We will do this by taking classifications or typologies as a point of departure. By choosing three different kinds of classifications, we intend to illustrate the major normative questions in this field. In a third step, we will review the literature that has mapped which EEPs are actually used by work organisations and evaluations of such programmes.

\section{Different concepts and perspectives}

We have just given a general indication of what EEPs aim to achieve a non-discriminatory outcome in terms of 'ethnicity' or 'immigrant background' - but such a general definition does not come without its problems. In the literature, 'employment equity policy' is increasingly 
used as a catch-all term for related concepts like 'affirmative action', 'equal opportunities policy', 'positive action' and 'diversity management' (Jain et al. 2003). 'Equity' is a normative concept that can be interpreted in various ways (Stone I988). 'Employment equity' obviously means different things to different people.

Three broad meanings may be distinguished: I) equal treatment; 2) equal results; and 3) individual recognition. Relating these meanings to discrimination, one could say that equal treatment refers to the absence of direct discrimination, whereas equal results aim to do away with structural discrimination. ${ }^{5}$ The difference is that the latter form of discrimination cannot be reduced to a particular social agent's bias against the disadvantaged group (Williams 2000: 64). Evidence of structural discrimination can only be found by looking at patterns of inequality at the level of groups or categories, whereas direct discriminators can be 'caught in the act' on the individual level. These differences of meaning - equal treatment versus equal results - have direct consequences for the instruments to be chosen for policies. This is even more the case when individual recognition, or 'recognition of unique characteristics of individuals' (including ethnic, cultural and religious ones), is the key meaning of employment equity. This concept is mostly associated with diversity management. Diversity management does not aim to promote justice - as is the case with equal treatment and equal results - but primarily to change the culture of organisations in order to make them perform better and use the diversity of personnel as an important means for such improvement. ${ }^{6}$

In view of such important differences in key concepts underlying EEPs, it is not surprising that the goals and instruments of EEPs and their interrelationships are hotly debated. There are not only different normative positions involved, but the three possible meanings of employment equity are not necessarily in harmony with each other, either. The research literature reflects this.

\section{Classifications of employment equity policies}

What can be characterised as the main components or elements of EEPs and how should these be interpreted? In the literature on EEPs, we find many classifications. Most authors order the different policy types along a continuum. They make distinctions between 'soft' and 'hard' policies, between 'strong' and 'weak', 'passive' and 'proactive', and even 'positive' and 'negative' policies. As a general background, we will use the analytical instrument furnished by McGinn and Borden (McGinn \& Borden 1995). According to them, policies generally contain four elements or stages that together make up a cycle: I) the goals 
or definition of the problem that needs to be tackled; 2) the instruments or the planning stage and determination of the actions and the physical resources needed; 3) the implementation or taking concrete actions and using resources; and 4) evaluation or monitoring the effects of the policy and the situation perceived to be problematic. But using that basic instrument leaves us with a number of choices as to whether we start with goals and definitions and then move to instruments and implementation, or the other way around; whether we take work organisations as units for our typology, or the content and orientation of forms of policies themselves, and so forth.

Our strategy is to highlight three major classifications in the following sections. In our view, these models have a state-of-the-art quality by providing a synthesis of existing research. The first one is Wrench's typology of organisational antidiscrimination activities (Wrench 2007). This typology has the advantage of outlining an impressive scope of possible EEPs. The second one, that of Kirton and Greene, takes organisations as units and uses the expressions of goals and the use of instruments to characterise these organisations' policies on a continuum of intensity (Kirton \& Greene 2005). The third is Glazer's theoretical typology of EEPs as programmes, based primarily on the quality of measures: from non-discrimination to hard affirmative action (Glazer 2000). Taken together, these classifications illustrate possible ways of characterising EEPs and the current debates in this field.

\section{Wrench's classification of employment equity policies}

In his book Diversity Management and Discrimination - Immigrants and Ethnic Minorities in the EU, Wrench gives an overview of the development of diversity management in Europe in relation to the issue of racial and ethnic inequality in employment (Wrench 2007). He develops an elaborate six-fold typology of employment equity policies, which he describes as 'a classification of levels or stages of antidiscrimination activity in organisational measures' (Wrench 2007: II5). The central focus of Wrench's classification is combating discrimination. The differences between the levels are both quantitative (the number of instruments and goals) and qualitative (different kinds of awareness). The typology is cumulative: higher-level activities may and mostly do contain a combination of lower-level activities and instruments. The different types of activities are ordered from the 'soft' end to the 'harder' end, including more ambitious policies and measures of which diversity management/mainstreaming is described as the most ambitious of all. Mainstreaming means that a certain goal becomes part and parcel of all organisational activities - it is always on the agenda. Wrench argues that the classification could also constitute 'a sequence of chronological 
stages': organisations first pass through a 'supply-side conscious' phase before they recognise the structural aspects of discrimination, and then develop a 'multicultural awareness' and an 'anti-racism awareness' (Wrench 2007: 54-55). Finally, Wrench states that higher-level activities may be more effective in combating discrimination, but that in the end the effectiveness of direct EEPs also depends on the country's historical, cultural and political context. ${ }^{7}$

Table 4.1 Wrench's 'classification of organisational antidiscrimination activities' (2007: 117)

\begin{tabular}{ll}
\hline Goals & Instruments \\
\hline \multicolumn{1}{c}{ Level 1. Training immigrants/minorities } \\
\hline $\begin{array}{ll}\text { To assist in their integration into society } & \text { Formal training for immigrants themselves } \\
\text { (Wrench 2007: 43) } & \text { 'to improve their education and skills, and } \\
\text { To combat different kinds of } & \text { to help them learn the language, culture } \\
\text { discrimination, 'depending on the context } & \text { and customs of the new society, and the } \\
\text { and the underlying rationale' (2007: 123): } & \text { appropriate ways of behaving, as well as } \\
\begin{array}{l}\text { opportunist discrimination, racist } \\
\text { discrimination, indirect discrimination and }\end{array} & \text { how to operate in the labour market' } \\
\text { past-in-present or historical discrimination } & \end{array}$ \\
\hline
\end{tabular}

Level 2. Making cultural allowances

To combat discrimination, only inasmuch Making allowances for specific religious or as it covers some of the elements of indirect discrimination (2007: 122)

Making allowances for specific religious or
cultural needs of minority groups within the organization

Training for some staff on cultural awareness or leading multi-ethnic teams Informing service providers such as social workers, teachers and doctors about immigrant cultures, realizing that "immigrants may have "special needs" related to their ethnic background' (2007: 43)

Level 3. Challenging racist attitudes

To combat different kinds of discrimination, if elements of this level are taken together with organisational activities at Levels 4 and 5 (2007: 122): racist discrimination, statistical discrimination, societal discrimination and indirect discrimination
Publicity and information campaigns Training to reduce people's prejudices or racist attitudes 
Level 4. Combating discrimination

To change people's behaviour as well as people's attitudes

To combat different kinds of discrimination, if elements of this level are taken together with organisational activities at Levels 3 and 5 (2007: 122): racist discrimination, statistical discrimination, societal discrimination and indirect discrimination
Introduction of fair recruitment and selection procedures, and training on how to operate these

Training on how to comply with antidiscrimination legislation Anti-harassment policies and training Introduction of disciplinary measures against racism and discrimination within the organisation

Level 5. Equal opportunities policies with positive action

To provide equal opportunities as the simple provision of equal treatment and the production of a 'level playing field' through removing discriminatory barriers' (2007: 44)

To combat different kinds of discrimination, if elements of this level are taken together with organisational activities at Levels 3 and 4 (2007: 122): racist discrimination, statistical discrimination, societal discrimination and indirect discrimination

To combat past-in-present or historical discrimination, if positive action initiatives are included
Equal opportunities policies, as 'a combination of the above approaches in a general equal opportunities package' (2007: 44), like:

- an equal opportunities statement for the organisation;

- a handbook for employees setting out the policy's intentions and procedures;

- a target, 'such as the long-term aim of reflecting the ethnic mix of the local population in the workforce' (2007: 44) 'Often there will be monitoring of the ethnic background of the workforce' (2007: 44)

Positive action initiatives as 'doing something extra for previously excluded minorities, something not being done for the national majority' (2007: 44), like:

- recognizing the existence of a sort of structural discrimination known as 'pastin-present discrimination' (Williams 2000, in Wrench 2007: 44);

- making an extra effort to encourage groups who might not normally apply (Wrench 2007: 44);

- translating job advertisements into ethnic minority languages;

- placing advertisements in the ethnic minority press;

- using statements to encourage applications from minorities;

- providing extra training related to the specific needs of immigrants and ethnic minorities to help them compete for work on a more equal footing with others in the labour market;

- mentoring to increase the retention of minorities once they have been recruited into the organisation;

- providing special training schemes for 


\begin{tabular}{|c|c|}
\hline & $\begin{array}{l}\text { immigrants and ethnic minority youth in } \\
\text { disadvantaged areas; } \\
\text { - supporting cultural programs in } \\
\text { disadvantaged areas }\end{array}$ \\
\hline \multicolumn{2}{|c|}{ Level 6. Diversity management/mainstreaming } \\
\hline $\begin{array}{l}\text { To value diversity (first stage) (Wrench } \\
2007: 44-45 \text {, based on Thomas 1990): } \\
\text { 'where there is a positive desire to work } \\
\text { towards an ethnically mixed workforce and } \\
\text { a recognition of the positive benefits that } \\
\text { a diverse workforce can bring to the } \\
\text { organisation' } \\
\text { To manage diversity (second stage) (Ibid.): } \\
\text { 'to contribute to organisational goals and } \\
\text { develop a heterogeneous organisational } \\
\text { culture' } \\
\text { In the long term to address institutional } \\
\text { discrimination (2007: 123) }\end{array}$ & $\begin{array}{l}\text { Diversity management 'can include many } \\
\text { or all of the elements of the other } \\
\text { approaches and adds diversity philosophy } \\
\text { and practice to this, mainstreamed in a } \\
\text { whole-organisational approach' (2007: 44) } \\
\text { 'Making cultural allowances for cultural } \\
\text { diversity is a standard component' (2007: } \\
71 \text { ) }\end{array}$ \\
\hline
\end{tabular}

\section{Kirton and Greene's classification of employment equity policies}

Gill Kirton and Anne-Marie Greene's second edition of The Dynamics of Managing Diversity - A Critical Approach discusses a wide variety of themes related to equality, diversity and discrimination in employment, focusing on the British and European context in particular (Kirton \& Greene 2005). One of the tools they provide is a classification of organisations according to their orientation towards equal opportunities and diversity policy. ${ }^{8}$ Kirton and Greene's classification is not intended as 'a picture of the reality of equality within organisations', but as an exploration of the different policy orientations in the United Kingdom. The different types of policies are again ordered hierarchically. It is a 'continuum', 'moving from approaches which can be characterised as reproducing inequality, to tackling discrimination, through to actively promoting equality and valuing diversity' (Kirton \& Greene 2005: 206). The typology is cumulative in terms of goals and instruments: higher-ordered types feature more of them. Kirton and Greene are quite explicit as to the normative character of their scheme. Offering terms and conditions for minority ethnic workers and positive action are described as progressive, and in their eyes, monitoring/auditing should be more than only a number registration tool. 
Table 4.2 Glazer's typology of employment equity policies

\begin{tabular}{|c|c|}
\hline Goals & Instruments \\
\hline \multicolumn{2}{|c|}{ Type 1. Non-discrimination } \\
\hline $\begin{array}{l}\text { To eliminate direct discrimination } \\
\text { 'The employment of persons with certain } \\
\text { levels of skill' (Glazer 2000: 140) }\end{array}$ & 'Neutrality in treatment' (2000: 139) \\
\hline \multicolumn{2}{|c|}{ Type 2. Soft affirmative action } \\
\hline $\begin{array}{l}\text { 'To improve the position of minority racial } \\
\text { and ethnic groups that have suffered from } \\
\text { racial and group discrimination. ... } \\
\text { [Affirmative action] goes beyond neutrality } \\
\text { in treatment ... to call for some degree of } \\
\text { special concern or preference' (2000: 139) } \\
\text { Soft affirmative action 'eschews the } \\
\text { attempt to reach a specific numerical goal' } \\
\text { (2000: 141) }\end{array}$ & $\begin{array}{l}\text { Outreach measures 'to seek out the } \\
\text { qualified of the underrepresented groups, } \\
\text { to inform them they are welcome and that } \\
\text { the employer ... is eager to employ ... } \\
\text { them' (2000: 140) } \\
\text { 'Employers may set up special programs } \\
\text { for persons from the underrepresented } \\
\text { groups to prepare them for higher skilled } \\
\text { jobs' (2000: 141) } \\
\text { There are many policies of this sort, like } \\
\text { 'policies of reaching out, advertising, } \\
\text { training, and preparing' (2000: } 141)\end{array}$ \\
\hline
\end{tabular}

Type 3. Hard affirmative action

'To improve the position of minority racial and ethnic groups that have suffered from racial and group discrimination. ...

[Affirmative action] goes beyond neutrality in treatment ... to call for some degree of special concern or preference' (2000: 139) To achieve 'certain numerical goals' (2000: 141)
Setting 'a target, a goal, a number so and so many Blacks, Hispanics, or women by such and such a date' (2000: 141)

Table 4.3 Kirton and Greene's 'continuum of forms of organisational approaches to equality and diversity' (2005: 206)

Goals Instruments

Type 1. The negative organisation

No goal like equal opportunities, diversity, No traditional equal opportunities policy or valuing diversity

or diversity policy

The organisation 'may (consciously or unconsciously) practice discrimination' (Kirton \& Greene 2005: 207)

Type 2. The minimalist/partial organisation

'This organisation will declare itself to be an equal treatment employer, and will probably follow management fashion and claim to value diversity' (2005: 207)
The organisation 'might not have a written EO or diversity policy, and will therefore not have developed comprehensive measures to overcome discrimination and 
promote equality and diversity' (2005: 207)

Type 3. The compliant organisation

Fulfilling legal obligations

'Paradoxically, this organisation may have switched to the individualist language of diversity in order to downplay social group-based disadvantage and discrimination' (2005: 207)
'A formal EO policy approach, probably developed and implemented by HR practitioners. The emphasis is likely to be on recruitment, and procedures will adopt 'good practice' as advocated by the statutory agencies' (2007: 207). This generally means the development of formalised bureaucratic procedures (Gibbon 1990, in Kirton \& Greene 2005: 208)

A 'form of positive action': targeted training to break down various forms of segregation and to achieve a more diverse workforce, like training programs for minority ethnic workers (Kirton \& Greene 2005: 210)

'Common features of traditional EO policies are arrangements for monitoring and auditing procedures, practices and outcomes to determine whether or not the objectives of the policy are being achieved' (2005: 211)

Type 4. The comprehensive proactive organisation

'The proactive organisation will emphasize the business case for equality and diversity, but will broaden the agenda to encompass elements of the social justice case' (2005: 207)

If positive action initiatives are included, 'the agenda moves beyond tackling discrimination towards promoting equality and valuing diversity' (2005: 207, see also 210)

One goal is to avoid indirect discrimination (2005: 217)
The organisation 'will comply with the law, it will aim to develop and implement "best practice" measures, and it will also monitor the outcomes of policy and practice in order to assess their impact' (2005: 207)

'Positive action initiatives might be a feature of policy here' (Ibid.), as for example formalized bureaucratic procedures in recruitment and selection, usually moving away from reliance on 'word of mouth' methods (Healy 1993, in Kirton \& Greene 2005: 209)

The organisation will advertise in locations that will reach the largest pool of applicants, may advertise in minority ethnic press and will construct advertisements carefully to avoid deterrence of certain social groups (Kirton \& Greene 2005: 209)

It may offer targeted training for underrepresented groups (2005: 210) It may also offer terms and conditions to facilitate the employment of underrepresented groups and to recognize 
and value diversity, like (2005: 210-211):

- arrangements for time off for religious observance;

- extended holiday leave for visiting family overseas;

- flexibility in relation to uniforms and dress codes to accommodate cultural and religious customs

\section{Glazer's classification of employment equity policies}

Ever since his 1975 classic Affirmative Discrimination, Nathan Glazer has been one of the most prominent critics of affirmative action in the United States (Glazer 1987). In 2000, he published an article concerning what Europe could learn from the experience of the United States: Affirmative Action and 'Race' Relations: 'Affirmative Action' as a Model for Europe. Glazer makes a distinction between three different types of policies. ${ }^{9}$ He also clearly orders the three types of policies hierarchically, from neutrality in treatment to hard affirmative action and numerical goals. Nonetheless, he strongly opposes hard affirmative action, because he believes that this type of employment equity policy may have unintended negative consequences such as societal controversy. ${ }^{\mathrm{IO}}$

\section{Existence of employment equity policies and their evaluation}

Now that we have a certain idea of the kind of equity policies that can be distinguished, how these relate to different goals and preferred outcomes, and the type of discrimination they target, we will look at the actual existence and effects of EEPs on the basis of underlying empirical data and case studies of relevant literature. Two preliminary remarks are in place here. The first is that empirical investigations of the implementation and evaluation of EEPs are usually motivated in two different ways. On the one hand, there are those who are mainly concerned with the so-called 'business case for diversity (management)'. ${ }^{\text {II }}$ On the other hand, one finds texts that are based on an antidiscrimination perspective, or what one might call the 'social justice case' for EEPs. The differences between these two perspectives are located in terminology, research questions and research designs. We will focus here on the second category of studies. ${ }^{\text {I2 }}$ Secondly, we would like the reader to keep in mind one of the basic problems of policy analysis: the difficulty of inferring causality. In most social contexts, the introduction of a policy is paralleled in time by a range of other changes that may influence the goal of the policy. From a methodological point of view, this makes it very difficult to measure the effects of the policy. 
In short, there is always room for interpretation in policy analysis, and all the more so when a highly controversial issue is at stake.

We will start our analysis of the actual existence and the effectiveness of EEPs by taking another look at the three classifications, which were all based on extensive collections of empirical data and evaluation studies.

\section{Empirical evidence in Wrench, Kirton and Greene and Glazer}

Wrench's classification is based on several major projects that were carried out in the I990s: the programme Combating discrimination against (im)migrant workers and ethnic minorities in the world of work of the International Labour Office (ILO); the European Compendium of Good Practice for the Prevention of Racism at the Workplace; ${ }^{\mathrm{I} 3}$ and Gaining from Diversity, an initiative of the European Business Network for Social Cohesion with the support of the European Commission. He also summarises two more recent European Commission reports: The Costs and Benefits of Diversity from 2003 and The Business Case for Diversity: Good Practices in the Workplace from 2005.

The ILO programme included a comparative project on antidiscrimination training in several European countries and the United States. The project concluded that the occurrence of antidiscrimination training was low and the training emphasis was quite different in the countries studied. The European Compendium and the report Gaining from Diversity included 30 cases that were analysed regarding the implementation of EEPs, leaving out cases that only described the intention of an organisation's policy. Even though the researchers were explicitly looking for policies that improved multicultural and anti-racism awareness, they only found four cases of what they called proper organisational equal opportunities or diversity policies. Fifteen cases were primarily concerned with the least ambitious policy of training immigrants/ minorities. Finally, the 2003 and 2005 European Commission reports indicate a growing awareness of diversity in European business. For the latter report, a questionnaire was sent out to around 3,000 companies in order to identify good practices, but only I2I of them replied and most of the reported initiatives were found to focus mainly on gender equality issues. In the end, less than half of the nineteen good practices in the text included ethnicity. As Wrench notes:

There is a growth in Europe in 'diversity consciousness' even though, strictly speaking, much of it to does not yet look like a diversity management consciousness, and some of these activities labelled diversity management might be more correctly categorised 
elsewhere on the earlier six-fold typology of organisational activity. (Wrench 2007: 64)

Kirton and Greene's classification is based on a thorough review of the British literature in particular. That review gives some hints on the effectiveness of policy instruments. When discussing recruitment and selection measures, they note that:

In fact there is some evidence of the efficacy of the kinds of approaches described here and found within proactive EO policies; workplaces with an EO policy employ proportionately more people from minority ethnic groups than do those without. (Kirton \& Greene 2005: 209)

The same cautiousness on effectiveness and an indirect observation on the spread of EEPs are also present when they comment on the state of the art of what we know about this field:

What is striking is that articles about equality initiatives in both the academic and practitioner journals tend to use the same few companies as examples, suggesting that the strategies adopted in the private sector, beyond a fairly limited list of exemplar employers, are generally less proactive. Nevertheless, it is important to highlight exemplars of good practice in order to provide encouragement and inspiration to key actors in other organisations. (Kirton \& Greene 2005: 210)

Since Glazer is a strong opponent of 'hard' affirmative action, we cannot expect much attention in his work to its possible positive effects. In fact, he doubts whether any of the policy types he distinguishes (non-discrimination, 'soft' affirmative action and 'hard' affirmative action) have been effective in terms of actual participation rates - what we have called the equal results-strand of employment equity. AfricanAmericans have experienced considerable improvement in their social and economic situation in the past decades, but this may be explained by other factors like the strength of the American economy, the general decline in racist sentiment and the migration of southern blacks to the north and west (Sowell I98I; Thernstrom \& Thernstrom 1997, in Glazer 2000: I5I). Apart from that, the black population still seems to be locked in a relative inferior position, caused by the history of slavery. He stresses that affirmative action has had the unintended effect of concentrating black employees in local, state and federal government, and of concentrating this target group in employers with governmental contracts, a result that he considers negative. In his view, the basic pro- 
blem is that affirmative action policies 'might simultaneously advance the interests of members of minority groups and increase the antagonism and resentment against them' (Glazer 2000: 138). Whether the costs outweigh the benefits, he argues, is a matter of interpretation.

From the abovementioned research, we cannot draw clear conclusions as to the actual existence and effectiveness of EEPs: the empirical evidence is not that strong due to low participation rates of businesses, and the actual effectiveness of policies is blurred by the influence of additional contextual factors. When we look at other literature on the actual existence and the effects of EEPs, however, we find some interesting examples from the Netherlands and the United States.

\section{Empirical evidence from studies in the Netherlands and the United States}

TNO, an established semi-governmental scientific institute in the Netherlands, published a report on diversity in the workplace in 2005 (De Vries et al. 2005). ${ }^{\mathrm{I}}$ This research project featured a survey among a representative sample of 500 Dutch organisations and an extensive portrait of ten different 'good practices'. In terms of policies, the researchers made a distinction between measures aimed at the inflow of ethnic minorities (coming to work in an organisation) and measures aimed at the promotion of ethnic minorities (the extent to which target group members make it to the higher ranks of the organisation). The idea behind this typology is that ethnic minorities face two obstacles: getting hired at all, and moving upwards from one job level to another once they get hired. The first type of policy was found in 15 per cent of all organisations, and the second one was found in 13 per cent. Only 7 per cent of the organisations had formulated both types of policies. In general, bigger organisations were more likely to have employment equity policies. The researchers also found considerable sectoral variation: service sector organisations were more active in terms of policies and employed a higher share of ethnic minorities on average. Interestingly, Dutch government agencies proved to have a special position: they were by far the most active in terms of policies (37 per cent had measures aimed at the inflow of ethnic minorities, 4I per cent aimed at promotion), but they lagged behind in terms of minority participation rates (4 per cent, compared to the national average of 7 per cent) (De Vries et al. 2005: I5-19).

In the United States, there is a long tradition of studying the effects of affirmative action, in various scientific disciplines. Most publications, however, deal with the effects of affirmative action as a governmental policy - as an indirect EEP, in terms of this chapter. These research projects examine for example whether black participation rates rise more quickly in companies that fall under affirmative action legis- 
lation. To our knowledge, there are only two exceptions: a study by Leonard on the late I970s and one by Holzer and Neumark on the early I990s (Leonard I985; Holzer \& Neumark 2000). ${ }^{15}$

In the I980s, Jonathan Leonard published a series of quantitative articles on affirmative action in the United States, the results of which were later summarised in an often-cited overview (Leonard I990). One of his publications partly dealt with a highly controversial policy instrument: the formulation of goals and timetables at the level of the organisation. In What Promises are Worth: The Impact of Affirmative Action Goals, he reported that establishments which promised to employ more blacks and women did actually witness an improvement in minority employment shares in subsequent years: total employment in these establishments fell by 3 per cent, but contrary to all expectations, white males were overrepresented in this decline. More ambitious affirmative action goals were strongly correlated with greater subsequent achievements, even though the actual achievements were much lower than the targets set. Apparently, these companies somehow succeeded in living up to their promises by protecting minority staff during periods of downsizing.

Leonard's sample consisted of 4,479 establishments that were reviewed by the Office of Federal Contract Compliance (OFCCP) in consecutive years. These companies were put under pressure by the government, which may have had a differential effect on the organisations' willingness to change the makeup of their workforce: for some, it might have been a wake-up call. Hence, Leonard's main conclusion is about the impact of affirmative action as an indirect EEP:

... [C]an we infer that extracting greater promises will result in greater achievement? The critical evidence is that there is an overall response to pressure. (...) My reading of this evidence is that while much of the nit-picking over paperwork is ineffective, the system of affirmative action goals has played a significant role in improving employment opportunities for members of protected groups. (Leonard I985: I9, emphasis added)

Although Leonard goes to great lengths to find how these companies succeeded in living up to their promises, he is not able to establish a clear causal chain, which makes him cautious in his recommendations:

What ultimately cannot be resolved with certainty here is the implication this has for policy beyond the important observation that goals appear to be neither so vacuous nor so rigid as their critics on either side have supposed. (Leonard I985: 19) 
Harry Holzer and David Neumark also noted the lack of understanding of the exact mechanisms by which the US government's policy of affirmative action seemed to affect minority employment at the level of work organisations. In their article What Does Affirmative Action Do?, they tried to open this 'black box' by empirically describing how behaviour differed among employers using and not using affirmative action. Central to their argument is the distinction between affirmative action in recruitment and affirmative action in hiring. Affirmative action in recruitment means that employers use search methods that are non-traditional for them but that enable them to find qualified women and minorities. These recruitment and screening instruments should generate more applicants from target groups, thus possibly countering different forms of discrimination. Examples include the use of state/ community or private agencies, referral from unions/schools and greater reliance on formal methods of screening. Affirmative action in hiring means that target group membership plays a role in who is actually hired. This second type may also be called preferential treatment. In American public opinion, it is often seen as a 'quota system' and is much more unpopular than the first type. Both types of affirmative action 'go well beyond simple non-discrimination in employment' (Holzer \& Neumark 2000: 268).

Based on a survey of over 3,200 employers in four metropolitan areas, Holzer and Neumark found that 55 per cent of the establishments were using some kind of affirmative action in recruitment, and 42 per cent in hiring. Almost all establishments (93 per cent) that were using affirmative action in hiring also did so in recruitment, but the reverse was not as true: 30 per cent reported using affirmative action in recruitment only. Both types of policy were positively correlated with establishment size, unionisation and the existence of a personnel department. Affirmative action was also more common in the services sector.

What were the employment effects of the two types of affirmative action in this study? Affirmative action in recruitment (the first type) increased the number of black female and Hispanic applicants. In terms of actual hires, affirmative action was 'weakly associated' with increased representation of white women, black men and Hispanics and decreased representation of white males, though the only statistically significant shift was in favour of Hispanic hires in jobs not requiring college degrees. When looking at the overall demographic composition of the establishments' workforces, the effects of affirmative action in recruitment seemed 'much stronger' - at least there were more significant positive effects. ${ }^{16}$ Nonetheless, widening the potential pool of applicants to encompass more women and minorities did contribute to some extent to their representation in actual employment. Still, Holzer 
and Neumark remain cautious, since there was little evidence for direct effects of changes in recruitment and screening methods.

The effects of affirmative action in hiring (the second type) were more consistent and clear. There were no significant effects on the number of minority applicants, but the effects on the inflow of new employees were more pronounced with statistically significant increases for both white women and black men, and statistically significant decreases in the probability that white men were hired. Surprisingly, however, some significant negative effects on black females were found as well, which suggests that EEPs may also reduce the chances of target groups to get hired. Affirmative action in hiring also had statistically significant effects on the diversity of the workforce: proportions of both white women and Hispanics increased. All in all, the effects on the different target groups were mixed and white women benefited most.

Finally, it is interesting to report on the relationship between affirmative action and training found by Holzer and Neumark, even though it is mainly formulated from a business perspective. In general, new employees in establishments with affirmative action received more training than elsewhere. In establishments that were using affirmative action in hiring, women and minorities received relatively more training, presumably because these establishments were more likely to hire candidates with lower qualifications. In these establishments, probationary periods were also used less often. Probably by combining affirmative action with special training, potential productivity losses were offset. Summing up:

When affirmative action is used in recruiting, it generally does not lead to lower credentials or performance of women and minorities hired. When it is also used in hiring, it yields minority employees whose credentials are somewhat weaker, though performance generally is not. (Holzer \& Neumark 2000: 240)

According to Holzer and Neumark, neither special recruitment and screening methods nor special training methods are as unpopular as 'quota systems'. In normative discussions on employment equity, however, there is no consensus on the question whether remedial training for discriminated groups should be offered before or after the selection process: in preparation of competition or after its closure. ${ }^{\mathrm{I7}}$

We conclude this section on the actual existence and effectiveness of EEPs with a discussion of an article by Alexandra Kalev, Frank Dobbin and Erin Kelly, who recently made an important contribution to the literature on direct employment equity policies. In Best Practices or Best Guesses? Assessing the Efficacy of Corporate Affirmative Action and Diver- 
sity Policies (Kalev et al. 2006), the authors systematically analyse the effects of three approaches on diversity in the management ranks of American private sector firms: I) organisational change; 2) behavioural change; and 3) treating social isolation. These three approaches are grounded in different social scientific theories of how organisations achieve goals (mainly organisational sociology), how stereotyping shapes behaviour at work (social psychology) and how networks influence careers. According to the authors, seven diversity programmes that are common in the United States may be grouped under these headings. In Table 4, their typology is depicted as yet another classification of direct EEPs. ${ }^{\text {I }}$

Table 4.4 Kalev, Dobbin and Kelly's three approaches to increasing managerial diversity

\begin{tabular}{ll}
\hline Goals & Instruments \\
\hline Ancreasing managerial diversity through & Affirmative action plan and responsible \\
establishing structures of responsibility & staff member \\
& Oversight and advocacy via committees \\
& Oversight via staff positions and \\
& departments \\
\hline
\end{tabular}

\begin{tabular}{ll}
\hline \multicolumn{2}{c}{ Approach 2. Behavioural change } \\
\hline $\begin{array}{ll}\text { Increasing managerial diversity through } & \text { Education via diversity training } \\
\text { reducing bias } & \text { Feedback via diversity performance } \\
& \text { evaluations }\end{array}$ \\
\hline
\end{tabular}

Approach 3. Treating social isolation

The common policy goal of increasing managerial diversity is firmly rooted in the equal results-tradition of employment equity. What counts for Kalev et al. in the final analysis is whether the three approaches and their instruments do anything to increase diversity.

In order to be able to distinguish between the effects of different types of policies in statistical terms, the researchers constructed a large-scale database describing the workforce of 708 companies in the United States from I97I to 2002, based on the so-called annual EEO-I reports. These are the reports that private employers with more than Ioo employees and government contractors with more than 50 employees and contracts worth more than $\$ 50,000$ are required to file each year to the Equal Employment Opportunity Commission under the Civil Rights Act. Over the years, survey data on companies' employment 
practices were added to the database, as well as a high number of control variables such as the economic context. The main research question was which of the seven diversity policy instruments help white women, black women and black men move at least into the bottom ranks of management and which do not.

On the sheer existence of the seven different policy instruments, Kalev et al. report the following. Affirmative action plans are by far the most common instrument in private sector workplaces that have to file annual EEO-I reports under the Civil Rights Act. From the I970s onwards, the percentage of companies with affirmative action plans rose steadily from about 20 per cent to $6_{3}$ per cent of the companies in the sample in 2002. This is not surprising, since federal contractors are required to have such plans. ${ }^{\text {I9 }}$ Starting at the beginning of the I990s, the popularity of diversity training increased sharply from less than Io per cent to 39 per cent in 2002 . The other five common policy instruments also showed increases during that decade: in 2002, I9 per cent of the companies had diversity committees, I9 per cent had networking programmes and I9 per cent had diversity evaluations for managers. Diversity staff members were appointed in II per cent of the establishments, and mentoring programmes were implemented in II per cent as well. All in all, 76 per cent of the respondents had adopted one of the seven instruments by 2002 and was thus doing 'something to promote diversity' (Kalev et al. 2006: 6II).

On the effectiveness of the different policies, Kalev et al. report that policies aimed at organisational change lead to the broadest increases in diversity in management staff: all three target groups (white women, black men and black women) seem to benefit from such policies. ${ }^{2 \circ}$ Furthermore, organisational change boosts other policy instruments aimed at behavioural change or treating social isolation, rendering them more effective. In comparison, policies aimed at behavioural change (the second approach) showed no effect, and those aimed at treating social isolation (the third approach) are described as disappointing because of their modest effects:

Broadly speaking, our findings suggest that although inequality in attainment at work may be rooted in managerial bias and the social isolation of women and minorities, the best hope for remedying it may lie in practices that assign organisational responsibility for change. (Kalev et al. 2006: 6Io-6II)

In other words, if a company makes a person or group of persons within the organisation responsible for the diversity policy, it is more likely to increase managerial diversity. 
Furthermore, the authors find differing effects for the different target groups. White women benefit most from diversity policies aimed at organisational change, black women come in second and black men benefit least. Both diversity evaluations and networking programmes show negative effects on the managerial representation of black men, and diversity training shows a negative effect on the representation of black women in management jobs, but no instrument has such effect on white women. The mere number of policy instruments matters for white women, whereas for blacks this is less important than the content of the policies. In addition, the interaction effect of the first approach with the other two approaches is different for the three target groups: organisational change only boosts networking programmes for black men and mentoring programmes for black women. ${ }^{2+}$ The authors conclude:

Even the programs that work best have modest effects, particularly for African Americans, who are poorly represented to begin with. (...) These programs alone will not soon change the look of management. (Kalev et al. 2006: 6II-6I2)

By means of conclusion, the authors stress the continuing importance of antidiscrimination legislation.

\section{Conclusions}

There are many different ways to frame and define 'employment equity'. In our attempt to review the literature, we have distinguished between equal treatment, equal results and individual recognition.

Equal treatment, or the absence of direct discrimination, is no longer controversial. A long tradition of research in this field has contributed to a change of public attitudes and stimulated antidiscrimination legislation and policies. The role of research can hardly be underestimated (Banton I994). It should be noted, however, that aiming at equal treatment alone leaves various other forms of discrimination untouched. Another basic difficulty is that unequal treatment is difficult to establish on a larger societal scale, as the policy approach is principally based on individual cases. Nevertheless, in view of the general acceptance of equal treatment as a norm in liberal-democratic societies, this definition of EEPs offers a solid starting point for such policies for private firms and governments alike. Tools developed within this approach are most frequently found in direct EEPs, although they may be used in a varying degree of intensity. 
Defining equal results (or the absence of structural discrimination) as the goal of EEPs is controversial. This approach doubts whether equal treatment 'automatically' leads to equal results on the group and societal level. Most scientists - but not all - would agree that there is an undesirable level of ethnic inequality in work organisations. This holds for the numerical representation of minority groups in management jobs in particular. The question is if this can and should be repaired with means that 'force' equal results. Do such means and instruments create unequal treatment of others, and do they have unintended effects that are more negative than the results attained? The controversies around such EEPs stem from the lack of consensus on the normative assumptions behind this approach.

The third definition of employment equity as individual recognition has mostly been dealt with in a business perspective: valuing the diversity of individuals is supposed to make the organisation function better and more productively. This may have become a more acceptable approach in recent times, since many individuals nowadays think of individual recognition as a moral goal in itself. The approach does not necessarily contribute to equal treatment or equal results, but it may be fruitfully combined with explicit antidiscrimination policies in certain contexts.

In the literature, there are many classifications of EEPs. There is a strong tendency to present a classification of EEPs as a continuum, from soft to hard, from negative to positive, and so forth. In this chapter, we have presented three of such classifications. Taken together, they give an exhaustive overview of possible policy instruments in this field. They also offer different ways of framing EEPs in organisational contexts, which can be useful for practitioners considering actions.

As for empirical evidence of the existence of direct EEPs, our overview suggests that we do find such organisational policies in countries that have, or have had a tradition of indirect EEPs. Governmental policies that force work organisations to be aware of inequality and discrimination and to take action against them obviously have an effect on the existence of the organisations' policies. The US, Canada and European countries such as the Netherlands, Sweden and the UK seem to have relatively more work organisations with direct EEPs than other countries, and these are also the countries where research on the topic exists. This applies particularly to those EEPs that are based on equal treatment and equal results. The third approach, that of individual recognition, has developed in recent decades out of a different tradition that is more connected with diversity as a business case, to be discussed in the following chapter.

Apart from this general statement on the relative existence in different countries, the literature is not able to offer a representative picture 
of the phenomenon. The fragmented picture that can be inferred from the literature is that work organisations with a governmental character or related to government by contracts most frequently have EEPs, but such characteristics are not a guarantee that they have such policies. The same goes for size and sector: bigger organisations are more likely to have EEPs, as are service-sector organisations. In the US, which has a long tradition of indirect EEPs, there may be a spillover of direct EEPs to work organisations that are not related to government. Another possible explanation for the differences between the US and Europe is the different legal context: in the US, the potential costs of court cases are higher. In any case, European work organisations with EEPs are still an exception to the rule.

When it comes to the question of what instruments are used in direct EEPs, we see a great variety of instruments and combinations. Awareness training is one of the most frequently used, whereas controversial instruments such as recruitment targets and strict monitoring are less common. Research on the effectiveness of each of the instruments is scarce, and conclusions often variant.

On the level of effectiveness of policies, there is an interesting key message in the American literature: organisational policies matter. Thus, Leonard shows that more ambitious organisations live up to their promises to the authorities to a certain extent, Holzer and Neumark show that affirmative action in hiring partly functions as 'outright preferential treatment', and Kalev et al. show that organisational change may lead to increases in managerial diversity. Such results are hopeful. They imply that pressure should be put on work organisations: they can actually take responsibility, even though they are simultaneously influenced by societal forces beyond their control.

Perhaps the argument can be made that all three US-based contributions make the same point: 'organisations that really want to increase the diversity of their workforce may be able to do so'. In this interpretation, it is not the lack of instruments to be used or the general effectiveness of each of these instruments that is decisive, but commitment of actual decision makers. Firstly, maybe organisations that really want to increase the diversity of their workforce formulate more ambitious goals and are on average more successful. Secondly, these organisations let target group membership play a role in who is actually hired and hire more members. Thirdly, organisations that really want to increase the diversity of their workforce make a person or group of persons within the organisation responsible for the policy and are on average more successful. ${ }^{22}$ This would suggest that the key factor for more equality in actual representation lies in getting commitment to this definition of employment equity in the boardrooms and management circles of companies and other work organisations. 
Finally, research in this field is still scarce and fragmented. Our knowledge about the existence of direct EEPs is not more than impressionistic. Evaluations of the effects of instruments and programmes are not only scarce and difficult to undertake, but the evaluations that do exist only record modest effects in general, and the range of possible unintended consequences is not adequately documented yet. Taken together, the state of the art of research seems to suggest that direct EEPs may have the potential to contribute to solving the problem of ethnic inequality and discrimination in employment under certain conditions, but they are certainly no panacea for that. In this spirit, most authors implicitly or explicitly emphasise the continuing importance of changing public attitudes through education, the mass media, politics and legislation. Both direct and indirect employment equity policies should remain high on the research agenda.

\section{Notes}

I Nowadays, some companies put pressure on their business partners to stimulate 'equal opportunities' or 'diversity' (Mor Barak 2005; Wrench 2007: I0).

2 Some NGOs, however, have been founded specially to campaign on this issue. An NGO is defined here as an organisation representing civil society (Van Tulder 2006: 28).

3 The absence of EEPs on the national level in Europe does not prevent EEPs from existing on the local level. In the CLIP Project, a comparative project of 'Cities for Local Integration Policies' that started in 2006, an inventory and comparative analysis was made of 'diversity policies in employment and service provision' in 25 European cities. The project includes British cities like Wolverhampton and Sefton, but also continental cities like Amsterdam, Copenhagen, Stuttgart and Vienna, all of which turned out to have varying forms of EEPs. The CLIP case studies and the comparative synthesis report can be downloaded at www.eurofound.europa.eu.int. The e-library of the European Urban Knowledge Network (EUKN) at www.eukn.org also contains the case studies.

4 In the remainder of this chapter, we will use 'EEPs' to mean 'direct EEPs'.

5 Direct discrimination may also be termed 'intentional discrimination', as Wrench argues (2007: 104-107). Structural discrimination includes indirect discrimination, past-in-present discrimination and side-effect discrimination; see Williams 2000 and Wrench $1996,2007$.

6 See also the overview of Kirton \& Greene 2005: I25.

7 The table is based on Chapters 3 and 6 of Wrench's book ('The Background to Diversity Management in Europe' and 'Diversity Management and Antidiscrimination').

8 The classification builds on the work of Healy (I993, in Kirton \& Greene 2005: 206) and a theoretical discussion on equality and diversity in Chapter 5 of Kirton and Greene's second edition. Please note that their volume is not only about 'minority ethnic people', but also about women, the elderly and disabled, and gay men and women, though these groups are not included in this chapter.

9 Note that his work also deals with affirmative action in education and housing, areas that are not covered in this chapter. 
Io Due to the abstract nature of Glazer's classification, which is centred around the issue of numerical goals, it may be interpreted as a typology of both indirect and direct employment equity policies. For instance, governments that force employers to advertise broadly in order to reach targeted groups may be said to put indirect EEP Type 2 into practice: 'soft affirmative action'. In any case, the measures he categorises are designed to be taken at the organisational level.

II For an elaboration of the business case for diversity management, see the Chapter 5 of this volume.

I2 In Chapter 5, we will discuss research concerning the business case for diversity.

I3 This project resulted from the Joint Declaration on the Prevention of Racial Discrimination and Xenophobia and Promotion of Equal Treatment at the Workplace, signed by the social partner organisations in Florence in October 1995.

I4 Note that this report also includes target groups such as women and the elderly.

I5 Kalev et al. 2006 also noted this.

I6 Hispanics in the United States might form a special group in the sense that informal recruitment methods are more important in the 'ethnic economy' in Hispanic areas (Falcon \& Melendez I997, in Holzer \& Neumark 2000: 256).

I7 See for example Sowell 2004: 220.

I8 The table is based on the theoretical part of their article (Kalev et al. 2006: 589-595).

I9 Still, 7 per cent of the federal contractors in the sample never had a plan. Conversely, 20 per cent of firms that had never had a contract worth more than $\$ 50,000$ formulated organisation-level affirmative action plans (Kalev et al. 2006: 592).

20 That is, eight out of nine possible relationships between the three policy instruments of the first approach and the three target groups are positive and significant. The only exception is the relationship between corporate affirmative action plans and the representation of black women in management functions: this effect is close to zero and insignificant (Kalev et al. 2006: 605).

2I In turn, the responsibility structure interaction positively affects white women in the case of diversity training or diversity evaluation (the two instruments of the second approach) (Kalev et al. 2006: 607).

22 A possible interpretation of Leonard I985, Holzer \& Neumark 2000, and Kalev et al. 2006, respectively.

\section{References}

Abell, J. P., M. C. Groothoff \& I. L. M. Houweling (I995), Etnische minderheden bij de overheid. Een onderzoek naar belemmerende factoren voor indiensttreding van leden van etnisch minderheden bij de overheid. The Hague: Ministry of Home Affairs.

Abella, R. S. (I984), Equality in Employment. A Royal Commission Report. Ottawa: Ministry of Supply and Services Canada.

Abella, R. S. (ed.) (I985), Equality in Employment. A Royal Commission Report, Research Studies. Ottawa: Ministry of Supply and Services Canada.

Adams, R. J., G. Betcherman \& B. Bilson (I995), Good Jobs, Bad Jobs, No Jobs. Tough Choices for the Canadian Labour Law. Toronto: C.D. Howe Institute.

Agocs, C. (2002), 'Canada's employment equity legislation and policy, I987-2000 - The gap between policy and practice'. International Journal of Manpower 23 (3): 256-276.

Agocs, C. \& C. Burr (I996), 'Employment equity, affirmative action and managing diversity: Assessing the differences'. International Journal of Manpower I7 (4-5): 30-45.

Appelt, E. \& M. Jarosch (eds.) (2000), Combating racial discrimination: affirmative action as a model for Europe. Oxford: Berg. 
Bacchi, C. L. (1994), 'Positive Action in the Netherlands. Reshaping a reform agenda', Nemesis Io (I): 3-II.

Banton, M. (1994), Discrimination. Buckingham: Open University Press.

Bovenkerk, F. (I986), Een eerlijke kans: over de toepasbaarheid van buitenlandse ervaringen met positieve actie voor etnische minderheden op de arbeidsmarkt in Nederland. Den Haag: Ministerie van Binnenlandse Zaken and Ministerie van Sociale Zaken en Werkgelegenheid.

Dagevos, J. M. \& M. A. M. M. Beljaarts (1996), Vijf jaar voorkeursbeleid: instroom, doorstroom en uitstroom van minderheden bij de Rijksoverheid. Rotterdam: Instituut voor Sociologisch-Economisch Onderzoek (ISEO), Erasmus Universiteit Rotterdam.

De Vries, S., C. van de Ven, M. Nuyens, K. Stark, J. van Schie \& G. C. van Sloten (2005), Diversiteit op de werkvloer: hoe werkt dat? Voorbeelden van diversiteitsbeleid in de praktijk. Hoofddorp: TNO Kwaliteit van Leven.

De Vries, S., M. Nuyens, R. W. M. Gründemann, M. R. de Bruin \& M. Willemsen (2002), Deuren open voor doelgroepen: participatie van vrouwen, allochtonen, gehandicapten en ouderen. Hoofddorp: TNO Arbeid.

Falcon L. \& E. Melendez (I997), The Social Context of Job Searching for Racial groups in Urban Centers. Boston: Mimeo, Northeastern University.

Glastra, F. J., P. E. Schedler \& E. Kats (I998), 'Evenredigheidsbeleid tussen markt en overheid: een vergelijking van Canadese en Nederlandse ontwikkelingen', Migrantenstudies: driemaandelijks tijdschrift voor onderzoek naar etnische minderheden en de Nederlandse samenleving I4 (3): I54-I7I.

Glazer, N. (1987), Affirmative discrimination: ethnic inequality and public policy. With a new introduction by the author. Cambridge, MA: Harvard University Press.

Glazer, N. (2000), 'Affirmative Action and "Race" Relations: Affirmative Action as a Model for Europe', in E. Appelt \& M. Jarosch (eds.), Combating Racial Discrimination. Affirmative Action as a Model for Europe, I37-I55. Oxford/New York: Berg.

Gras, M. \& F. Bovenkerk (1995), Preventing racism at the workplace: The Netherlands. Dublin: European Foundation for the Improvement of Living and Working Conditions.

Holzer, H. J. \& D. Neumark (2000), 'What Does Affirmative Action Do?', Industrial and Labor Relations Review 53 (2): 240-27I.

Jain, H. C. \& J. L. Lawler (2004), 'Visible Minorities under the Canadian Employment Equity Act, I987-I999', Relations industrielles 59 (3): 585-6II.

Jain, H. C., P. J. Sloane \& F. Horwitz (2003), Employment equity and affirmative action: an international comparison. With Simon Taggar and Nan Weiner. New York: M.E. Sharpe.

Jonkers, P. (2003), Diskwalificatie van wetgeving. De totstandkoming en uitvoering van de Wet bevordering evenredige arbeidsdeelname allochtonen (Wbeaa). Amsterdam: Aksant.

Kalev, A., F. Dobbin \& E. Kelly (2006), 'Best practices or best guesses? Assessing the efficacy of corporate affirmative action and diversity policies'. American Sociological Review 7I (4): 589-6I7.

Kelly, E. \& F. Dobbin (1998), 'How affirmative action became diversity management', American Behavioral Scientist 4I (7): 960.

Kirton, G. \& A. M. Greene (2005), The dynamics of managing diversity: a critical approach. Second edition. Amsterdam: Elsevier Butterworth-Heinemann.

Kurthen, H. (1997), 'The Canadian experience with multiculturalism and employment equity: lessons for Europe', New Community (23) 2: 249-270.

Leonard, J. S. (1985), 'What Promises Are Worth: The Impact of Affirmative Action Goals', The journal of human resources: education, manpower and welfare policies I: 3-20.

Leonard, J. S. (I990), 'The impact of affirmative action regulation and equal employment law on black employment', Journal of Economic Perspectives 4 (4): 47-63. 
McGinn, N. F. \& A. M. Borden (I995), Framing questions, constructing answers: linking research with education policy for developing countries. Cambridge, MA: Harvard Institute for International Development.

Mentzer, M. S. \& J. L. Fizel (I992), 'Affirmative Action and Ethnic Inequality in Canada: The Impact of the Employment Equity Act', Ethnic Groups 9: 203-2I7.

Moore, R. (I997), Positive Action in Action. Equal Opportunities and Declining Opportunities on Merseyside. Aldershot: Ashgate.

Mor Barak, M. E. (2005), Managing diversity: toward a globally inclusive workplace. Thousand Oaks, CA: Sage.

Skrentny, J. D. (I996), The ironies of affirmative action: politics, culture, and justice in America. Chicago: University of Chicago Press.

Sloane, P. J. \& D. Mackay (I997), 'Employment equity and minority legislation in the UK after two decades: a review', International Journal of Manpower I8 (7-8): 597-626.

Smeets, H. M. A. G. (I993), Etnische minderheden bij de overheid. Faal- en slaagfactoren bij positieve-actiebeleid. TWCM Voorstudie 3, Den Haag: Ministerie van Onderwijs, Cultuur en Wetenschappen.

Soininen, M. \& M. Graham (2000), 'Positive Action in Sweden: from Central Solutions to Local Responsibility for Combating Ethnic Discrimination', in E. Appelt \& M. Jarosch (eds.), Combating Racial Discrimination. Affirmative Action as a Model for Europe. Oxford/New York: Berg.

Sowell, T. (2004), Affirmative action around the world: an empirical study. New Haven, CT: Yale University Press.

Stone, D. A. (I988), Policy paradox and political reason. Glenview, IL.: Scott Foresman and Co.

Taylor, P. (2000), 'Positive Action in the United Kingdom', in E. Appelt \& M. Jarosch (eds.), Combating Racial Discrimination. Affirmative Action as a Model for Europe. Oxford/New York: Berg.

Thomas, A. (2002), 'Employment equity in South Africa: lessons from the global school'. International Journal of Manpower, 23 (3): 237-255.

Van Tulder, R. (2006), International business-society management: linking corporate responsibility and globalisation. With Alex van der Zwart. London: Routledge.

Ventura, C. (2000), 'Racial Discrimination and Affirmative Action: Canada's Experience with Antidiscrimination Legislation', in E. Appelt \& M. Jarosch (eds.), Combating Racial Discrimination. Affirmative Action as a Model for Europe. Oxford/New York: Berg.

Verhoeven, H. \& A. Martens (2002), Imponerend stimuleren. De mogelijke brug tussen redelijke aanpassing en onevenredige belasting? Leuven: Departement Sociologie en Hoger instituut voor de arbeid (HIVA), Katholieke Universiteit Leuven.

Williams, M. S. (2000), 'In Defence of Affirmative Action: North American Discourses for the European Context?', in E. Appelt \& M. Jarosch (eds.), Combating Racial Discrimination. Affirmative Action as a Model for Europe, 6I-80. Oxford/New York: Berg.

Wrench, J. (I996), Preventing racism at the workplace: a report on 16 European countries. Luxembourg: Office for Official Publications of the European Communities.

Wrench, J. (2007), Diversity management and discrimination. Immigrants and ethnic minorities in the EU. Aldershot: Ashgate.

Wrench, J. \& T. Modood (2000), The effectiveness of employment equality policies in relation to immigrants and ethnic minorities in the UK. Geneva: International Labour Office (ILO). 



\title{
5 Diversity management and the business case
}

\author{
Michael Fischer
}

\section{Introduction}

Managing for diversity is a management strategy that intends to make productive use of differences between individuals, ethnic and otherwise. It is based on the premise that - at least if they are well managed - diverse teams will produce better results and diverse companies will gain a market advantage. In contrast to other employment equity policies, diversity management is primarily driven by the 'business case', i.e. by the argument that diversity and/or its management will increase organisational efficiency and profitability. With diversity management as a business practice becoming more and more popular in Europe, the question arises as to whether this policy actually delivers the business benefits that its advocates claim. This question becomes increasingly relevant to anyone involved in the discussion and implementation of employment policies relating to ethnic and other minorities. An examination of the literature, however, shows that there is no unanimous answer regarding the business benefits of diversity and its management. While the business case seems to be rather self-evident for many advocates of diversity management, academic research on the effects of diversity provides mixed and inconclusive results and has led critics to see a 'mismatch between research results and diversity rhetoric' (Kochan et al. 2003: 5). This chapter will I) describe the characteristic features of diversity management and its benefits as described by its proponents; 2) give an overview of the way in which diversity management is implemented; 3) examine the business case for diversity (this will include a discussion of research results regarding the effects of diversity upon performance and a discussion of intervening variables that will influence this impact); and 4) conclude by focusing on the performance-related diversity effects for the business case for diversity management. I will argue that this relevance is limited as the business case for diversity management and the business case for diversity are two interconnected, but different issues. 


\section{What is diversity management?}

\section{Definitions of diversity management}

There is no such thing as a single, authoritative definition of diversity management. Rather, 'diversity management' refers to a set of ideas and practices that have been defined and described in various ways. As its name suggests, diversity management is a management strategy. It is applied predominantly top-down, as a managerial instrument. Its purpose is to enhance the effectiveness and/or productivity of organisations. The central idea of 'managing diversity' is that this organisational improvement is to be achieved through recognising, valuing, promoting and utilising diversity - whereby 'diversity' refers to many, if not all sorts of differences between individuals (cf. e.g. Kirton \& Greene 2005: I23ff). A starting point could be the definition by Kandola and Fullerton:

The basic concept of managing diversity accepts that the workforce consists of a diverse population of people. The diversity consists of visible and non-visible differences which will include factors such as sex, age, background, race, disability, personality and work style. It is founded on the premise that harnessing these differences will create a productive environment in which everybody feels valued, where their talents are being fully utilised and in which organisational goals are met. (Kandola \& Fullerton I998: 8)

Other definitions might place more or less emphasis on aspects such as the rationale of enhancing organisational efficiency or profitability, on the idea of appreciating and valuing differences, or on the goal of constructing an inclusive environment. For example, Schwarz-Wölzl and Maad define diversity management as 'a management instrument for systematically considering, internally and externally, how diversity can be used to enhance the success of a company, and for consciously utilising and promoting diversity to this end' (Schwarz-Wölzl \& Maad 2004a: 5, own translation). Bartz et al. speak of diversity management as ' $\mathrm{u}]$ nderstanding that there are differences among employees and that these differences, if properly managed, are an asset to work being done more efficiently and effectively' (Bartz et al. I990: 321, quoted in Wrench 2007: II). According to Mor Barak, the term refers to

the voluntary organisational actions that are designed to create greater inclusion of employees from various backgrounds into the formal and informal organisational structures through deliberate policies and programmes. (Mor Barak 2005: 208) 
The German Association for Diversity Management defines the term as 'the purposeful perception, the honest appreciation, and the conscious utilisation of differences' - 'diversity is the pivotal topic of management and enhances business success through increased productivity and improved market position' (DGDM 2007, own translation).

The fact that the term 'diversity' is used in the literature in fundamentally different ways can cause confusion and is not particularly elegant in a conceptual sense. Firstly, 'diversity' refers to heterogeneity. Secondly, 'diversity' is used to denote the characteristics in which individuals can differ. Thirdly, 'diversity' is used to describe an attitude that values diversity, and fourthly, 'diversity' is used as shorthand for the diversity management approach itself (cf. Wrench 2007: 8). In the following, the term 'diversity' will refer to heterogeneity and will be distinguished from attitudes valuing diversity and a policy of diversity management.

\section{Differences from other employment equity policies}

The general idea of diversity management differs in some important aspects from other employment equity policies (cf. e.g. Kirton \& Greene 2005; Wrench 2007):

1. Valuing and promoting diversity as something positive

In diversity management, diversity is emphatically seen as something positive. Diversity in organisations is not viewed as something that must be achieved for the sake of complying with legal or moral norms, but as something that should be achieved and should be desired in order to produce an environment in which people can realise their full potential and maximise organisational successes. Advocates of diversity have been creative in coining metaphors pointing to the stimulating and enriching effects of a diverse workforce. 'Differences', Kandola and Fullerton say, 'come together to create a whole organisation in much the same way that single pieces of a mosaic come together to create a pattern (Kandola \& Fullerton I998: 8). Each piece is acknowledged, accepted and has a place in the whole structure' (quoted in Wrench 2007: 7). In much the same way, other authors have compared diversity in organisations to a painter's palette (where different colours are more pleasant if they remain different and are not mixed to become grey (Mor Barak 2005: 292)), to an orchestra that needs many kinds of instruments, etc.

\section{Increasing organisational efficiency}

The primary purpose of diversity management is to increase organisational efficiency. For profit-oriented organisations, this means gaining market advantage and maximising profits. In other words, the primary rationale of diversity management is the 'business case' rather than the 
case for social justice. While diversity management certainly emphasises equality and non-discrimination, these are - theoretically - subordinate goals. In reality, they are means to achieve more efficiency. Therefore, the idea of diversity management implies a hierarchical but harmonious relationship between market advantage and equal opportunities for ethnic and other minorities: market advantage comes first, but action directed towards maximising profits is thought to be necessarily directed towards equal opportunities and ethnic equality, because an organisation that values and promotes diversity will be more competitive, while an organisation that discriminates against minorities will be less so. It is conceivable that this idea might sometimes be used as a subterfuge to convince employers to implement policies directed at equal opportunities and multiculturalism by appealing to what they are presumably more interested in. It would be interesting to know how many of the promoters and practitioners of diversity management really see organisational effectiveness as their primary goal, and for how many others the issue of effectiveness is a sales argument for multiculturalism instead. But regardless of how the primary intentions of diversity management advocates might be distributed empirically, if diversity management theory is right, market advantage and an inclusive multiculturalism go hand in hand.

\section{Broad understanding of diversity}

Diversity management is based on a broad, sometimes apparently allinclusive understanding of 'diversity': many, if not all sorts of differences between individuals are to be taken into account. Other than equal employment opportunities and affirmative action (EEO/AA), which are policies that focus upon specific differences like gender, ethnic or 'racial' differences, diversity management considers more or less any sort of diversity to be relevant. For example, the Ford Motor Company states that 'Diversity in the workplace includes all differences that define each of us as unique individuals' (quoted in Schwarz-Wölzl \& Maad 2004a: 43). Typical examples of specific differences in question include differences in sex, age, ethnicity, 'race', culture, nationality, religious beliefs, sexual orientation, physical ability and education. Nonetheless, it is regularly indicated that such lists are not exhaustive and only provide examples of differences. Human characteristics that can differ and thus constitute diversity are categorised in a number of ways. Readily observable attributes are distinguished from not so readily observable ones, visible differences from invisible ones, inner dimensions from outer dimensions, etc. ${ }^{\mathrm{I}}$ A popular classification of differences distinguishes primary dimensions from secondary dimensions, but there is no consistency in the literature as to what exactly the primary and the secondary dimensions are. Griggs saw age, ethnicity, gender, physical abilities/ 
qualities, race and sexual orientation as the six primary dimensions (Griggs 1995). These are said to be 'inborn and/or (...) exert an important impact on early socialisation and have an ongoing impact throughout life' (Wrench 2007: II). In contrast, secondary dimensions of diversity would be characteristics 'that can be changed' (Wrench 2007:I2), such as income, educational background, marital status, parental status, religious beliefs and others. Other authors might count religion as a primary dimension and add 'physical appearance' to the primary dimensions, or include geographic location, occupational career, language and lifestyle in the secondary (cf. Wrench 2007:I2; DGDM).

However the dimensions of diversity might be classified, the claim to include most or all differences in the policy implies that diversity management is not directed towards specific groups (like women or ethnic minorities). As every person differs in some regard from others, and as all sorts of differences should be taken into account, diversity management is directed towards every employee or the staff as a whole - including members of dominant or majority groups like white men that have decisively not been the focus of earlier EEO/AA approaches. Diversity management should benefit everyone and, thereby, the organisation itself.

\section{Transforming the organisational culture}

Finally, diversity management is seen as an attempt to bring about a thorough change, a transformation of organisational culture (cf. Kirton \& Greene 2005; Kersten 2000). Rather than focusing upon recruitment and selection only, the aim is to create an all-inclusive 'culture of diversity' that penetrates the organisation and is not confined to the separate realm of a specific equity policy (Rees I998, quoted in Kirton \& Greene 2005: 125). A vision for effective diversity management is the idea of the multicultural organisation as envisaged by Cox (Cox 1993). This type of organisation would be 'characterised by a culture that fosters and values cultural differences - truly and equally incorporates all members of the organisation via pluralism as an acculturation process, rather than as an end resulting in assimilation' (Mor Barak 2005: 2I7). The multicultural organisation has 'full integration, structurally and informally, is free of bias and favouritism toward one group as compared with others, and has only a minimal intergroup conflict' (ibid.).

\section{The benefits of diversity management}

With increasing organisational efficiency as the major goal, there are a number of ways in which diversity management is said to achieve this end. While the reasons for which particular organisations implement 
diversity management might differ, there are several advantages of diversity management that are regularly pointed out (cf. e.g. Süß \& Kleiner 2005; Kossek \& Lobel I996; Dass \& Parker 1996; Wrench 2007).

\section{Making use of talents}

With talents being short - and maybe becoming shorter due to demographic developments - it would be unreasonable for organisations to focus upon homogeneity and not make use of existing talents. A policy of diversity simply increases the pool of potential employees to choose from, and it might also make companies more attractive for potential employees from minority backgrounds.

\section{Access to markets and legitimacy with partners and customers}

As markets globalise and societies become more diverse, organisations are dealing with a variety of different partners and customers both at home and abroad. By reflecting this diversity in a diverse staff, companies might firstly strive to gain a better image with their customers as well as their partners. Secondly, minority communities are recognised as markets of growing importance, markets that might better be entered if knowledge about the customers' preferences is available within the company. Thirdly, and ironically, the diversity of the staff can be a way to account for the customers' actual or presumed taste for homogeneity. If for example ethnic groups prefer to deal with staff of their own ethnicity, it will be useful for a company to have that staff available.

\section{Advantages through synergy}

A central idea of diversity management is the assumption that when diverse teams are well managed, they produce better results due to internal dynamics. What we could call the synergy hypothesis assumes that heterogeneity will enhance group performance through changing group processes: diverse teams, the idea goes, will profit from a greater variety of perspectives resulting in better solutions to problems, increased creativity and more innovation. Ideally, processes of intercultural exposure and mutual learning should lead to effects of cultural synergy that benefit the organisation as well as everybody involved.

\section{Productive advantages of an inclusive environment}

Diversity management strives to create an environment in which differences are valued, in which special needs are taken into account and in which every individual feels respected and acknowledged. It is believed that this inclusive setting will create a situation in which people can work more productively and achieve their full potential (cf. Cox I993: 225). Job satisfaction should be enhanced, turnover reduced and the de- 
velopment of synergy effects should be facilitated in an inclusive environment.

\section{Avoiding the costs of discrimination}

While the absence of discrimination is an end in itself, there are also business arguments for equality. On the one hand, discrimination will impede the utilisation of all available talents and create a working environment in which people feel uncomfortable and dissatisfied. On the other hand, discrimination might cost money due to legal penalties. In the US, as Wrench points out, the pressure of equal employment opportunity and affirmative action programmes may have been one of the reasons fostering the continuation of diversity management (Wrench 2007: 19). Effective diversity initiatives may 'assist in the reduction and prevention of costly lawsuits relating to race discrimination, sexual harassment, and gender discrimination lawsuits' (Wentling \& Palma-Rivas 1997: 2I, quoted in Wrench 2007: 2I).

\section{The implementation of diversity management}

Regarding its practical implementation, there is no definite and well defined set of measures that constitute diversity management. Rather, we find a multitude of various steps and programmes, some of which might be implemented in particular diversity management initiatives, while others might not. As even basic approaches or individual measures may be called 'diversity management' (cf. Aretz \& Hansen 2002), the mere information that a company implements or reports to have implemented 'diversity management' is not very meaningful.

\section{Central components of diversity management}

Implementing diversity management might begin by analysing the company/organisation in its present state by answering some of the following questions: Which languages do the clients speak? Which countries does the company operate in? How high is employee turnover? How much does the company spend on discrimination or harassment suits? Are there group conflicts within the company? Do the employees feel valued and satisfied (cf. Schwarz-Wölzl \& Maad 2004a: 42)? Following this analysis, a variety of programmes can be applied. Pitts has suggested a distinction between three central components of diversity management measures: I) recruitment programmes; 2) programmes aimed to increase cultural awareness; and 3) pragmatic management policies (Pitts 2005: I2). Recruitment programmes in diversity management are aimed at systematically increasing the diversity of employees. 
Programmes aimed to increase cultural awareness have the goal of minimising the potential costs of heterogeneity and maximising effects of cultural synergy. This might include awareness and skill-building training (cf. e.g. Ford \& Fisher 1996; Jamieson \& O’Mara I99I), but also the promotion of internal advocacy groups, mentoring programmes and paying attention to representation (cf. e.g. Kellough \& Naff 2004). Pragmatic management policies are policies directed at increasing flexibility and job satisfaction by taking the needs of a diverse staff into account (cf. e.g. Lobel \& Kossek I996). This might include benefits for part-time employees, support for single parents, the provision of childcare facilities, flexible dress codes, room for religious practices, specialised equipment for disabled persons, flexible working hours or the translation of company-related information into languages represented among the staff.

\section{Characteristic elements of diversity management}

Many of the individual measures of diversity management have already been employed in earlier EEO/AA programmes, as we saw in the typologies described in Chapter 4. Sometimes, the difference between diversity management and other equity policies might be somewhat overstated (cf. Wrench 2007: I4). Nevertheless, the mode of implementation of diversity management is said to imply some characteristic elements. For diversity management, leadership commitment and the involvement of top management play a central role. Diversity management is initiated as a top-down process, and managing for diversity should constitute a strategic element of the business plan (Wrench 2007: I2; Schwarz-Wölzl \& Maad 2004a: 44f). The formulation of company-specific definitions of 'diversity' and of 'diversity missions' are common practice, demonstrating commitment to diversity in a prominent and authoritative way. Even if it is coming from top-level management, communicating the diversity policy to the staff is essential. According to the Society for Human Resource Management, this should include for example the explanation of the business case, the explanation of possible effects of diversity management for productivity and the company's goals, the communication of the benefits diversity management will have for every employee, and the explanation of the process of diversity management (cf. Schwarz-Wölzl \& Maad 2004a). This process, during which the organisation should be transformed towards a culture of diversity, is expected to take several years - diversity management is not seen as a set of measures that can quickly be implemented and that will have immediate effects. In the course of the organisational transformation, commitment to diversity is to become an integral part of the organisational culture, and complying with the requirements of the di- 
versity policy may become a part of both individual and organisational performance evaluations (ibid.).

\section{Evaluation or benchmarking as a part of diversity management}

Ideally, the evaluation of its effects should form a part of the implementation of diversity management. This could include analysing variables such as job satisfaction, engagement and behavioural changes among the employees, the development of individual and group achievements, the productivity of the organisation as well as turnover, absenteeism and profitability (cf. Cox I993: 24I). Nonetheless, it is very difficult to evaluate the effects of diversity management due to the large number of factors influencing each of these variables, and due to the multitude of possible causal relations between them. Less satisfying than an actual evaluation, but more feasible and therefore probably implemented more often, is a sort of benchmarking for diversity. For example, the Center for Diversity and Business has created a 'Diversity Assessment Tool' using a five-step 'diversity continuum', which specifies not the effects of diversity management but the degree to which the diversity idea has been implemented and internalised (so that external pressures have transformed into internal motivation); the levels range from 'compliance' to 'beyond compliance', 'business case', 'integrated diversity', and finally 'global employers and suppliers of choice', the highest possible score. At this final level, 'diversity' has become a management imperative reaching beyond the organisation itself and shaping all external relations as well (cf. Schwarz-Wölzl \& Maad 2004a: 47f). Instead of measuring the results of diversity management, this sort of benchmarking assesses the commitment to diversity management.

\section{The business case: the diversity-performance link}

\section{The benefits of diversity and diversity management: evidence from surveys and case studies}

While the benefits of diversity seem almost self-evident for advocates of diversity management and for many companies applying diversity policies (cf. European Commission 2005: 7), the actual evidence that diversity and/or its management enhance organisational performance, efficiency and outcomes is less clear and conclusive. Surveys and qualitative data representing companies' experience with or opinion on diversity policies and their respective benefits indicate considerable positive results of diversity and diversity management.

Of the 505 member companies of the European Business Test Panel that responded to the question of whether diversity initiatives have a 
positive impact on their business, 83 per cent answered positively (European Commission 2005: 53). The two major groups of benefits of a diverse workforce that companies in this survey reported to have experienced or to expect were access to a new labour pool and the attraction of high-quality staff (cited by 43 per cent of all participating companies), and benefits related to reputation, corporate image or good community relations ( 38 per cent). A little more than a quarter of the companies ( 26 per cent) rated innovation and creativity as a benefit of a diverse workforce (European Commission 2005: 53).

Among some I2O companies in four EU countries with 'active diversity policies' that were asked to assess the importance of various potential benefits of those policies, a majority considered the following either 'important' or 'very important': the strengthening of cultural values within the organisation, enhanced corporate reputation, helping to attract and retain highly talented people, improved motivation and efficiency of existing staff, improved innovation and creativity among employees, enhancing service levels and customer satisfaction and helping to overcome labour shortages. Between one-fourth and one-half of the companies also rated reduced labour turnover, lowered absenteeism rates, improved access to new market segments, avoiding litigation costs and improving global management capacity as important or very important benefits (European Commission 2003: 3; Centre for Strategy $\&$ Evaluation Services 2003).

In addition to surveys reporting positive impacts of diversity and diversity management, collections of good practice examples indicate similar positive results, as do the qualitative data obtained in case studies (e.g. European Commission 2005; Schwarz-Wölzl \& Maad 2004b; Centre for Strategy \& Evaluation Services 2003).

Opinions presented by companies or their representatives as they are collected in surveys or interviews are important, but also questionable data when it comes to evaluating the effects of diversity and diversity management. On the one hand, the persons filling out surveys or giving interviews will often be persons responsible for, and committed to, diversity and diversity management, and answers might therefore be biased; moreover, particularly when reports about a company are not anonymous, there will be a strong interest of representatives to provide a positive image of the company and its policies. On the other hand, experiences of companies or their representatives are often not based on actual measurement. There is a 'lack of systematic monitoring and evaluation of the progress and benefits of diversity' (European Commission 2005: 6), 'little evidence of quantitative assessment of costs or benefits' of diversity policies and 'also little evidence of any systematic measurement of costs, benefits and intermediate outcomes' (European Commission 2003: 4). 


\section{Diversity and group performance: mixed evidence}

In addition to surveys and case studies that look into the benefits of diversity policies, the idea of the 'business case for diversity' has stimulated a growing body of academic research on performance-related outcomes of diversity. Nonetheless, there is hardly any research that objectively measures the financial benefits of diversity and diversity management on an organisational level. That is to say, the central promises of diversity management are basically untested. Instead, most studies focus on the link between diversity and group performance regarding the handling of specific tasks, and thus have put one claim of diversity rhetoric under particular scrutiny: the synergy-assumption that diverse teams produce better results.

Overall, the results of such research evoke a less optimistic picture than companies report. On the one hand, there are indeed a number of studies that indicate increased performance in diverse groups. Innovation and creativity in problem solving have been observed to be higher in heterogeneous groups as compared to homogeneous ones, suggesting that minority viewpoints may stimulate creative processes. Heterogeneous groups have been observed to be more likely to consider a greater number of alternative solutions and to come up with higherquality solutions to problems (cf. Thompson \& Gooler 1996). Be that as it may, such findings are far from consistent, and reviewers of academic research on effects of diversity continue to assert that the evidence for positive effects is mixed, inconclusive and in part simply lacking (e.g. Wise \& Tschirhart 2000; Williams \& O'Reilly I998; Pitts 2005). Gender diversity has frequently been observed to be positively related to performance (cf. Pitts 2005: 7), but in various studies, mixed-sex groups have both performed better and worse than singlesex groups (cf. Ely \& Thomas 200I: 234). The same is true for 'racially' or ethnically diverse groups: while some studies have shown a positive relation between 'racial' or ethnic diversity and performance, others have demonstrated a negative relation or no relation at all (cf. Ely \& Thomas 200I: 234; Pitts 2005: 7).

\section{Research on diversity effects: weak reliability, validity and generalisability}

Apart from providing mixed results, the quality of research on diversity effects is often questionable. Wise and Tschirhart reviewed to6 empiri$\mathrm{cal}$, theory-testing studies on the effects of diversity in the workplace and found reliability, validity and generalisability to be weak (Wise \& Tschirhart 2000). Originally intending to conduct a meta-analysis of statistical findings, Wise and Tschirhard found that there were not enough cumulative and consistent findings to do so. Searching for stu- 
dies that analysed the effects of specific types of diversity upon specific work outcomes, there was often only one study that addressed the same combination of diversity dimension and outcome. For the rare combinations that offered ten or more findings, the authors found mixed results, incomparable measures and a differing use of control variables (Wise \& Tschirhart 2000: 39I).

Moreover, the design of many studies on diversity effects does not allow for any immediate conclusions about effects in and upon actual organisations. While effects on the organisational level are of major importance regarding the business case for diversity management (as its central promise is that organisational performance will be improved), effects of diversity have predominantly been studied on individual and group levels: 'The lack of empirical research on organisation-level outcomes [of diversity] is troubling, given the emphasis in the literature on the organisational-level benefits of the managing-for-diversity approach' (Wise \& Tschirhart 2000: 389). Another point of criticism has been that many studies on the effects of diversity have measured performance in laboratory settings (using students as research subjects, for example). These studies lack so many of the contextual factors of actual organisations that the applicability of such research is highly questionable (e.g. Wise \& Tschirhart 2000; Williams \& O'Reilly I998; Thompson \& Gooler I996). In contrast, research in real organisations is comparably underdeveloped, especially when it comes to applying reasonably objective performance measures (cf. Kochan et al. 2003). With maybe just a little overstatement, we could say that while opinions from diversity management practitioners reflect experiences in real organisations but are rarely based on systematic measurement of effects, a considerable part of the academic research measures effects that might bear little relation to the mechanisms found in actual organisations.

\section{Research in real world settings: an example}

Research in actual organisations, however, does not consistently point to positive diversity effects, either. One example is the work that has been done by the Diversity Research Network, an association of researchers who analysed the effects of 'racial' and gender diversity on the performance of teams, workgroups and business units (cf. Kochan et al. 2003). Research took place in four companies, all of which had an established commitment to managing diversity - two information processing firms, a financial services firm and a retail company. The researchers' report gives interesting insights into the practical problems of examining the effects of diversity in actual organisations, which in part might explain why this sort of research is rarely con- 
ducted. To recruit companies for this research, more than twenty large Fortune 500 companies (all of which showed considerable interest in the topic) were contacted and involved in discussions over a two-year period. All but four declined, for reasons such as the lack of influence of the company's diversity advocates, a reluctance to examine the effects of policies that already had sufficient support without 'proof' of the business case, or objections by legal counsels or by managers who would have had to provide data. All four companies that agreed to participate had a prior relationship with members of the research network or its partner initiative, and therefore already had established a high level of trust. Among the four remaining companies, it was not possible to collect the same kind of data and use the same research instruments: 'Each company had its own particular ways of collecting and storing human resource data and three of four firms indicated a strong preference for using their own internal survey measures to capture the variables in the model' (Kochan et al. 2003: 8). Using a variety of quantitative and qualitative data on diversity and constructing means to measure team performance (from performance appraisal ratings, goal achievement ratings, bonus systems and average sales), the results of the four studies showed that there was no simple and unequivocal relationship between diversity and team outcomes. 'Racial' and gender diversity as such did not have a consistently positive or negative impact. While negative impacts of 'racial' diversity were evident, they proved to be mitigated by training. Gender diversity sometimes had no effect on group processes, and it sometimes had a positive effect. The authors emphasise that effects of diversity are rarely direct, and that 'context is crucial in determining the nature of diversity's impact on performance' (Kochan et al. 2003: I7). For example, a highly competitive context aggravated the negative effects of 'racial' diversity. By contrast, 'racial' diversity may enhance performance in an environment that promotes learning from diversity.

\section{Diversity effects: positive and negative potentials}

Kochan et al. suggest that the value of diversity management may primarily lie in reducing the negative effects of diversity, and only secondarily in promoting the positive effects: 'If these studies are representative of other leading companies with similarly strong commitments to diversity, our results may suggest that efforts to create and manage diverse workforces have generally paid off by eliminating many of the potentially negative effects of diversity on group processes and performance documented previously in the literature. Moreover, there appear to be some conditions under which diversity, if managed well, may even enhance performance'(Kochan et al. 2003: I7). With this assess- 
ment, Kochan et al. are in line with reviewers of the research on the effects of diversity. Unless steps are taken to counteract the negative effects of diversity, Williams and O'Reilly say:

...the evidence suggests that, by itself, diversity is more likely to have negative than positive effects on group performance. Simply having more diversity in a group is no guarantee that the group will make better decisions or function effectively. In our view, these conclusions suggest that diversity is a mixed blessing and requires careful and sustained attention to be a positive force in enhancing performance. (Williams \& O'Reilly I998: I29, quoted in Wrench 2007: 85)

Other authors place more emphasis on the positive findings that do exist, while adding that positive results are not always to be expected: 'Consistent positive findings for diversity or heterogeneity have been reported in both the research conducted in laboratory settings and that done in real world settings'. Nonetheless, 'A key finding from all of the research conducted thus far is that the presence of diversity in a work team doesn't just automatically lead to positive outcomes such as enhanced productivity' (Thompson \& Gooler I996: 402). Still others are unable to decide whether diversity effects are more positive or negative: 'Given the weaknesses in the body of research on diversity, we can draw no firm conclusions for public administrators. We cannot claim that diversity has any clear positive or negative effects on individual, group, or organisational outcomes' (Wise \& Tschirhard 2000: 392).

Whether the effect of diversity 'in and of itself' might be more negative or just not automatically positive, empirical research suggests that diversity does not lead to improvements in team performance under all conditions. Most observers agree that diversity has the potential for positive effects (such as increased creativity, innovation and flexibility) as well as for negative effects (such as communication problems and increased conflicts) and that the actual effects strongly depend upon contextual factors.

\section{Contextualising the impact of diversity}

Using this observation as a point of departure, a policy of managing diversity should ideally be based on an answer to the following question: Which context variables will influence group and organisational-level impacts of which types and degrees of diversity in which way? Be it due to the complexity of the field, the problems conducting research in actual organisations, or perhaps the fact that the question is simply too 
broad, there is still no coherent, detailed and satisfying model suitable for providing a comprehensive answer. Nevertheless, the literature offers some basic models and does point to a number of factors that may have an impact on the relationship between diversity and organisational outcomes. When thinking about managing diversity, this should definitely be taken into consideration.

\section{Types of diversity}

To begin with, the effects of diversity will vary with types of diversity. Theoretically, there is no compelling reason to believe that all types of differences between people (such as age, gender, ethnicity, education, sexual orientation, physical abilities, values, beliefs, etc.) should have the same effects upon group performance. It comes as no surprise that empirical research suggests varying effects for various types of diversity (cf. e.g. Wise \& Tschirhart 2000). When distinguishing between types of diversity, the discourse of diversity management focuses upon differences that are relevant for the construction of social identities and that result in potential unequal treatment - these include gender, 'racial' or ethnic differences. From a theoretical point of view, however, it is important to further distinguish identity diversity from cognitive diversity (i.e. diversity in knowledge, perspectives and interpretations) and diversity regarding preferences. Page argues that cognitive diversity produces benefits while preference diversity creates problems (Page 2007). For identity diverse groups, this would mean that they will perform better than homogeneous groups only if (a) the identity diversity translates into cognitive diversity relevant for specific tasks, and (b) the identity diversity does not translate into preference diversity. Nonetheless, as

identity diverse collections of people often contain both types of diversity, they perform both better and worse than homogenous groups as well. Put differently, identity diverse teams, cities, and societies can perform better, but they often fail to do so. (Page 2007: 299)

\section{Degrees of diversity}

An aspect that seems rather obvious, but often is not systematically taken into account, is that effects of diversity will also vary with degrees of diversity. This is another reason why it is somewhat imprecise to talk about effects 'of diversity' as such. If we take all possible sorts of diversity into account, every group will necessarily be diverse in some regards. The question is not so much if diverse groups perform better than non-diverse groups, but to what extent more diversity leads to bet- 
ter performance than less diversity. If we want to establish whether more diversity leads to better performance than less diversity, we will first have to determine what is to be counted as more or less diversity. For many types of diversity, notably also for ethnic diversity, this is not as obvious as it might seem at first sight. For example, if Company A has 50 employees of ethnicity $\mathrm{x}$ and 50 of ethnicity y, while Company B has 70 employees of ethnicity x, I5 of ethnicity y and I5 of ethnicity $z$, which one is more diverse? Or if Company A has 50 employees of ethnicity $\mathrm{x}$ and 50 employees of ethnicity $\mathrm{y}$, while Company B has 50 employees of ethnicity $x$ and 50 of ethnicity $z$, could they show different degrees of diversity according to varying 'distances' (i.e. smaller or larger differences) between $\mathrm{x}, \mathrm{y}$ and $\mathrm{z}$ ? An index to calculate ethnic/cultural or other forms of diversity could take into account the number of types represented (richness), the relative abundance of types (evenness) and the distance between types (Bellini 2005). While this leaves open the essential question as to how to determine and measure this 'distance', it will be more useful to recognise the problem of an operationalisation of degrees of diversity than to talk about 'diversity' as if it were a dichotomous phenomenon that is simply either present or not.

\section{The mode of economic activity}

Particular types and degrees of diversity will probably exert different effects according to the economic sector in which a company is working or the mode of economic activity that is present in a company or parts of it. Broomé et al. (2000) have argued that ethnic diversity always has the potential for positive effects such as increased flexibility, creativity, openness, criticism and knowledge transference and for negative effects such as increased conflicts, communication problems or cultural clashes (cf. Wrench 2007: 88). Nonetheless, these impacts of diversity will be quite different in the manufacturing sector than in the service sector. Communication plays a minor role in manufacturing, and this sector may be less susceptible to the benefits and costs of diversity, whereas the service sector will be more affected both by the positive and negative effects of diversity. Consistently, Audretsch and Thurik contrasted traditional routinised economic activities with knowledgebased innovative activities and argued that the former will benefit more from homogeneity, while the latter will profit more from diversity (Audretsch \& Thurik 2000: 89).

\section{Organisational context}

Within one economic sector, the effects of diversity will vary with a multitude of context variables. A basic model that takes various organi- 
sational context variables into account has been presented by Kochan et al. (Kochan et al. 2003). The authors assume that diversity can have negative and positive effects that are mediated by group processes, and that this connection is affected by organisational context variables. Diversity (the model names cultural, demographic, technical and cognitive diversity) would thus influence group processes like communication, conflict, cohesion, information and creativity. These group processes would then have an impact on organisational outcomes like performance, satisfaction and turnover. Nonetheless, the way in which diversity affects group processes and group processes affect outcomes depends upon organisational culture, business strategy and human resource policies and practices.

While such a model is useful to remind us of the overall importance of organisational context, the categories 'organisational culture', 'business strategy' and 'human resource policies and practices' are still very broad and would need to be developed in more detail as well as complemented by other factors. Among the many variables that can possibly intervene between diversity and outcomes, the literature indicates factors such as the emotional involvement of the actors, coalitions and past communications, the complexity of the task to solve, organisational size, structure and technology, organisational communication mechanisms or type and frequency of the interaction of group members. Moreover, there might be interactions between various dimensions of diversity and there is some evidence suggesting that diversity effects will change over time (cf. Wise \& Tschirhart 2000; Pelled I996; Thompson \& Gooler 1996).

\section{Diversity perspectives}

As is already indicated in the notion of 'organisational culture', because diversity effects are social phenomena, they will vary according to processes of the perception and interpretation of the differences in question. A central difference between a mosaic and a diverse group of individuals is that individuals will observe other individuals, will know that they are being observed by others as well and will change their behaviour according to the resulting patterns of the perception of others, the perception of self and the significance given to the perceived differences. One implication of this fact is that - as Ely and Thomas have found - the very perspective on diversity that is prevailing in a company, the 'diversity perspective', will influence the effects of diversity (Ely \& Thomas 200I). But the implications reach far beyond organisational culture. Effects of diversity will probably vary with the wider cultural setting (e.g. the difference between an individualist and a collectivist culture), with historical and political contexts, with cultural identi- 
ties and power relations (cf. e.g. Wise \& Tschirhart 2000; Ely \& Thomas 200I) - the effects of diversity within a group or organisation will in part be influenced by social context factors well beyond the scope of the organisation or its management.

\section{The business case for diversity management}

The question of whether or not diversity increases organisational performance seems deceivingly simple. Upon closer examination, however, it involves a plethora of complex and interdependent variables to be considered. Taking into account varying types and degrees of diversity, the multitude of meanings that they might have for social actors (and that only constitute a 'type' of diversity in a proper sense of the term), the multitude of organisational and social context factors that will probably intervene (among them, and not least of all, the effects of management policies), and the multitude of possible outcomes on individual, group and organisational levels, it may not come as a surprise that research does not provide a simple answer. Therefore, it seems that while we have an overview of the context factors that do play a role, in the end the impact of specific types of diversity upon performance will be either positive, negative, or none at all, and we do not have a coherent and tested theory able to explain and predict the exact outcomes in real-world situations.

The case for diversity and the case for diversity management: two different issues

What does this state of evidence mean for diversity management? Some critics argue that scientific evidence supporting the business case is lacking, and that the 'diversity industry' is simply earning a lot of money selling diversity training and advice when the business benefits of diversity are not proven by research. The consequence seems to be that a rational employer would have to abandon diversity management until such proof exists. An example of a popular interpretation of research results following this logic is from an article published in Workforce Management. The author argues:

The multibillion-dollar diversity industry is thriving in corporate America. But before you spend another dime on your diversity program, carefully consider this conclusion reached by Thomas A. Kochan, one of the most respected human resources management scholars in the country: 'The diversity industry is built on sand,' he declares. 'The business case rhetoric for diversity is simply na- 
ive and overdone. There are no strong positive or negative effects of gender or racial diversity on business performance.' (Hansen 2003)

While it is true that the diversity rhetoric is often naive and overstated, the conclusions that are drawn here - if, as it seems, they are based on Kochan et al.(2003)- also reach too far. The study in question compared the performance of teams, work groups or business units within companies that showed a commitment to managing diversity; it did not compare the performance of companies with and without diversity policies and therefore could not objectively assess the organisational-level performance-related impact of these policies.

It is dangerous to overestimate the relevance that research on the synergetic performance effects of diversity has regarding whether diversity management makes sense for organisations. The synergy hypothesis the idea that diversity will enhance group performance through changing group processes - is of course of major importance in the literature advocating diversity management, while there is ambivalence as to whether diversity 'as such' or a managed diversity is supposed to deliver these results. It is this hypothesis that much of the research in the field has also focused upon, mostly testing the diversity-as-such version of the thesis. When this version of the synergy hypothesis is shown to be not generally true, some observers consider the case for diversity and thereby the case for diversity management to be gravely impaired. Nonetheless, the case for diversity management must not be confused with the task of a mere assessment of performance-related synergy effects of diversity, and it is misleading to discuss both questions under the common heading 'the business case for diversity'. Upon closer examination, there are two reasons why the performance-based case for diversity and the case for diversity management must be considered as two separate issues.

\section{Diversity management may change diversity effects}

Firstly, and rather obviously, the synergetic effects of diversity may change through diversity management. It is quite possible that specific types of diversity as such may produce inconsistent and sometimes negative results depending on context factors, while an appropriately managed diversity may lead to various benefits, including increased efficiency. Research does suggest that managing diversity may be a way to mitigate potential negative effects of diversity while promoting potential positive effects (cf. e.g. Thompson \& Gooler I996; Kochan et al. 2003). Even if the effects of diversity 'as such' were primarily negative, it would still be a positive result of diversity management to compen- 
sate for this fact. Thus, while studies on the impact of diversity indeed indicate that the 'diversity is good for organisations' mantra (Wrench 2007: 85) found in much of the managerial literature has been overstated, this might not constitute an argument against, but for a sensible diversity management that attempts to create conditions under which negative diversity effects are minimised and positive effects maximised - especially when the workforce is diverse anyway.

On the other hand, this does not mean that every single training and skill-building programme that operates under the name of 'diversity management' is actually beneficial. Which programmes will enhance group processes and efficiency and which might be potentially useless or even counterproductive (cf. Wrench 2007: 9of) is a question that will have to be addressed by further research that evaluates individual programmes.

\section{Most potential benefits of diversity management are not effects of diversity}

Secondly, the strong focus on the synergy effects of diversity is misleading, because diversity management policies in practice consist of several components and cannot be reduced to the attempt to try to enhance synergies. A rough modelling of the impact of diversity management, which takes several components of diversity management into account separately, has been presented by Pitts (Pitts 2005). He suggests that a) the recruitment and outreach component; b) the 'building cultural awareness' component; and c) the pragmatic management policies will have an impact upon different variables, namely on a) integration and increased organisational heterogeneity; b) cultural synergy; and c) job satisfaction. These variables would commonly influence organisational performance. Of course, such a model can only be the beginning of a more detailed modelling of the effects of diversity management. The different components of diversity management, the groups of effects, as well as 'organisational performance' itself, again imply various different approaches and variables that would have to be differentiated in a more detailed model. Nonetheless, it is useful to keep in mind that diversity management may have a number of impacts and that different components of diversity management may have different impacts. If we now reconsider the benefits as suggested by its advocates, it becomes clear that the synergy hypothesis - whether it is proven true or false - is of little importance regarding all of the other suggested benefits: making use of talents, access and legitimacy, productive advantages of an inclusive environment, and avoiding the costs of discrimination (see above). All of these may be results of diversity management, while not being synergy effects of diversity. 
That companies have more of a choice of talented personnel if they broaden the scope of their search towards a greater variety of potential employees is almost self-evident. Making use of talents among minority groups is an effect of diversity management, but not an effect of $d i$ versity - it only means to allow for diversity. Whether diversity in a company will improve access to markets and legitimacy with partners and customers will depend upon the characteristics of the markets, partners and customers in question. If minority markets are or can become relevant for a company and minority knowledge facilitates entry into them, if investors take diversity into account when making an investment decision, if a company has international partners and communication is facilitated through a diverse staff, if customers have a taste for homogeneity that is satisfied through a diverse staff, then access and legitimacy will be improved through diversity. Again, these results could be improved through diversity management, but they are not synergy effects of diversity. They are effects of having relevant competencies at hand and of pleasing interaction partners, which has nothing to do with diversity-improving group processes. The productive advantages of an inclusive environment are manifold. First, an inclusive environment is said to enhance synergies and in this regard, it is related to the synergy hypothesis. Research suggests that this improvement of synergy effects through diversity management is possible. Secondly, an inclusive environment is said to make people feel valued and work to their full potential. This would be an effect of diversity management, but again not an effect of diversity. Thirdly, an inclusive environment may enhance job satisfaction by taking into account the needs of a diverse staff. This again is not an effect of diversity - it is an effect of organisational adaptation to diversity. Reduced costs of discrimination, finally, may also be an effect of diversity management, but it is not an effect of diversity, either. It is an effect of complying with legal norms and of making minorities feel comfortable and accepted.

This means that most of the potential benefits that are claimed for diversity management are in fact not synergy effects of diversity or even effects of diversity at all. As it is applied in practice, diversity management has a lot to do with adapting to social conditions where both diversity and demands for inclusion exist anyway. It might have less to do with radical cultural transformations than its advocates suggest and less with synergy effects than researchers of the business case tend to assume. While focusing on the synergy hypothesis, both managerial advocates of diversity management and academic researchers may have overemphasised one potential benefit of diversity management (namely synergy) over all the others. Thus, if diversity management practitioners see clear benefits of diversity management while research suggests that the effects 'of diversity' are often questionable, this may be 
because practitioners follow wishful thinking more than evidence. But it may also be because researchers, influenced by the common confusion of diversity and diversity management and fascinated by the interesting and difficult synergy hypothesis, have been researching the effects of diversity more than the effects of diversity management - and have neglected the other, sometimes more obvious and simple potential business benefits of managing diversity.

\section{Note}

I For examples, see Schwarz-Wölzl \& Maad 2004a: 7ff.

\section{References}

Aretz, H. J.\& K. Hansen (2002), Diversity und Diversity-Management im Unternehmen. Eine Analyse aus systemtheoretischer Sicht. Münster: LIT.

Audretsch, D. \& R. Thurik (2000), 'Diversity, Innovation and Entrepreneurship', proceedings of the conference Workplace Diversity: A Research Perspective on Policy and Practice, Brussels School of Public and Environmental Affairs, Indiana University, June 2000.

Bartz, D. E., L. W. Hillman, S. Lehrer \& G. M. Mayhugh (I990), 'A model for managing workforce diversity', Management Education and Development 2I (4): 32I-326.

Bellini, E. (2005), 'Defining Cultural Diversity', presentation at $2^{\text {nd }}$ meeting of the study group on Diversity, Integration, and the Economy, Hamburg Institute of International Economics, Hamburg, 3 November 2005.

Broomé, P., B. Carlson \& R. Ohlsson (2000), 'Ethnic diversity and labour shortage: Rhetoric or realism in the Swedish context', paper presented at the conference Diversity Practice: Diversity Management and Integration. Ethnicity and Gender in Focus, Work and Culture, Swedish National Institute for Working Life, Norrköping, November 2000.

Centre for Strategy and Evaluation Services (2003), Methods and indicators to measure the cost-effectiveness of diversity policies in enterprises. Final Report, Ms.

Cox, T. (I993), Cultural diversity in organisations. Theory, research and practice. San Francisco: Berrett-Koehler.

Dass, P. \& B. Parker (I996), 'Diversity. A strategic issue', in E. Kossek \& S. A. Lobel (eds.), Managing diversity. Human resource strategies for transforming the workplace, 36539. Malden/Oxford: Blackwell.

Deutsche Gesellschaft für Diversity Management (DGDM) (2007), ManagingDiversity. www.diversity-gesellschaft.de, 8 October 2007.

Ely, R. J. \& D. A. Thomas (200I), 'Cultural diversity at work. The effects of diversity perspectives on work group processes and outcomes', Administrative Science Quarterly 46 (2): $229-273$.

European Commission (2003), The costs and benefits of diversity. Luxembourg: Office for Official Publications of the European Communities.

European Commission (2005), The business case for diversity. Good practices in the workplace. Luxembourg: Office for Official Publications of the European Communities. 
Ford, J. K. \& S. Fisher (I996), 'The role of training in a changing workplace and workforce: New perspectives and approaches', in E. Kossek S. A. Lobel (eds.), Managing diversity. Human resource strategies for transforming the workplace, I64-I93. Malden/Oxford: Blackwell.

Griggs, L. B. (1995), 'Valuing diversity: where from ... where to?', in L. B. Griggs \& L. L. Louw (eds.), Valuing diversity. New tools for a new reality, I-I4. New York: McGrawHill.

Hansen, F. (2003), 'Diversity's business case doesn't add up', Workforce, April: 28-32.

Jamieson, D. \& J. O'Mara (I99I), Managing workforce 2000. Gaining the diversity advantage. San Francisco: Jossey-Bass.

Kandola, R. \& J. Fullerton (1998), Diversity in action. Managing the mosaic. London: Institute of Personnel and Development.

Kellough, J. E. \& K.C. Naff (2004). 'Managing diversity in the federal service: Responding to a wake-up call', Administration and Society 36 (I): 62-90.

Kersten, A. (2000), 'Diversity management. Dialogue, dialectics and diversion', Journal of Organisational Change Management I3 (3): 235-248.

Kirton, G. \& A. Greene (eds.) (2005), The dynamics of managing diversity. A critical approach. Oxford: Butterworth-Heinemann.

Kochan, T., K. Bezrukova, R. Ely, S. Jackson, A. Joshi, K. Jehn, J. Leonard, D. Levine \& D. Thomas (2003), 'The effects of diversity on business performance. Report of the Diversity Research Network', Human Resource Management 42 (I): 3-2I.

Kossek, E. E. \& S. A. Lobel (I996), 'Introduction. Transforming human resource systems to manage diversity - an introduction and orienting framework', in E. Kossek \& S. A. Lobel (eds.), Managing diversity. Human resource strategies for transforming the workplace, I-I9. Malden/Oxford: Blackwell.

Lobel, S. A. and E. E. Kossek (1996), 'Human resource strategies to support diversity in work and personal lifestyles. Beyond the 'family friendly' organisation', in E. Kossek \& S. A. Lobel (eds.), Managing diversity. Human resource strategies for transforming the workplace, 22I-244. Malden/Oxford: Blackwell.

Mor Barak, M. E. (2005), Managing diversity. Toward a globally inclusive workplace. Thousand Oaks: Sage Publications.

Page, S. E. (2007), The difference. How the power of diversity creates better groups, firms, schools, and societies. Princeton/Oxford: Princeton University Press.

Pelled, L. (1996), 'Demographic diversity, conflict, and work group outcomes. An intervening process theory', Organisation Science 7 (6): 615-63I.

Pitts, D. W. (2005), 'Modelling the impact of diversity management', Research Paper Series, Andrew Young School of Policy Studies, Working Paper 06-18. Ms. www.aysps.gsu.edu/publications/2006.

Rees, T. (1998), Mainstreaming equality in the European Union. Education, training and labour market policies. London: Routledge.

Schwarz-Wölzl, M. \& C. Maad (2004a), Diversity und Managing Diversity, Teil 1: Theoretische Grundlagen. Vienna: Zentrum für Soziale Innovation.

Schwarz-Wölzl, M. \& C. Maad (2004b), Diversity und Managing Diversity, Teil 2 Fallbeispiele, Good Practice. Vienna: Zentrum für Soziale Innovation.

Süß, S. \& Kleiner, M. (2005), Diversity-Management in Deutschland: Ergebnisse einer Unternehmensbefragung, Fernuniversität in Hagen, Fachbereich Wirtschaftswissenschaft, Arbeitsbericht Nr. I5, Hagen.

Thompson, D. E. \& L. E. Gooler (I996), 'Capitalising on the benefits of diversity through workteams', in E. Kossek \& S. A. Lobel (eds.), Managing diversity. Human resource strategies for transforming the workplace, 392-437. Malden/Oxford: Blackwell.

Wentling, R. M. \& N. Palma-Rivas (1997), 'Current status of diversity initiatives in selected multinational corporations diversity', The Workforce Series Report 3, University 
of California at Berkeley: MDS-936, National Center for Research in Vocational Education.

Williams, K. Y. \& C. A. O’Reilly (I998), 'Demography and diversity in organisations. A review of 40 years of research', in B. M. Straw \& L. L. Cummings (eds.), Research in Organisational Behaviour 20: 77-I40.

Wise, L. R. \& M. Tschirhart (2000), 'Examining empirical evidence on diversity effects. How useful is diversity research for public sector managers?', Public Administration Review 6o (5): 386-395.

Wrench, J. (2007), Diversity Management and Discrimination. Immigrants and Ethnic Minorities in the EU. Aldershot: Ashgate. 


\section{List of contributors*}

Michael Fischer, Hamburg Institute of International Economics, Germany

Saskia Keuzenkamp, The Netherlands Institute for Social Research, The Hague; Department of Sociology, Faculty of Social Sciences, VU University, Amsterdam, the Netherlands

Eleonore Kofman, Social Policy Research Centre, Middlesex University, London, United Kingdom

Karen Kraal, Institute for Migration and Ethnic Studies, University of Amsterdam, the Netherlands

Angela Nilsson, Centre for Research in International Migration and Ethnic Relations, Stockholm University, Sweden

Rinus Penninx, Institute for Migration and Ethnic Studies, University of Amsterdam, the Netherlands

Judith Roosblad, Institute for Migration and Ethnic Studies, University of Amsterdam, the Netherlands

Patrick Simon, National Institute for Demographic Studies, Paris, France

Stijn Verbeek, Sociology Department, Erasmus University Rotterdam, the Netherlands

John Wrench, European Union Agency for Fundamental Rights, Vienna, Austria; Centre for Migration and Refugee Studies, Norwegian University of Science and Technology, Trondheim, Norway

* All contributors to this report are members of the IMISCOE Network of Excellence. Names appear in alphabetical order.

** Rinus Penninx serves as Scientific Coordinator of IMISCOE. 



\section{Other IMISCOE titles}

\section{IMISCOE Research}

Rinus Penninx, Maria Berger, Karen Kraal, Eds.

The Dynamics of International Migration and Settlement in Europe:

A State of the Art

2006 (ISBN 9789053568668 )

(originally appearing in IMISCOE Joint Studies)

Leo Lucassen, David Feldman, Jochen Oltmer, Eds.

Paths of Integration: Migrants in Western Europe (1880-2004)

2006 (ISBN 9789053568835 )

Rainer Bauböck, Eva Ersbøll, Kees Groenendijk, Harald Waldrauch, Eds. Acquisition and Loss of Nationality: Policies and Trends in 15 European Countries, Volume 1: Comparative Analyses 2006 (ISBN 9789053569207 )

Rainer Bauböck, Eva Ersbøll, Kees Groenendijk, Harald Waldrauch, Eds. Acquisition and Loss of Nationality: Policies and Trends in 15 European Countries, Volume 2: Country Analyses 2006 (ISBN 9789053569214 )

Rainer Bauböck, Bernhard Perchinig, Wiebke Sievers, Eds.

Citizenship Policies in the New Europe 2007 (ISBN 978905356922 I)

Veit Bader

Secularism or Democracy? Associational Governance of Religious Diversity 2007 (ISBN 9789053569993 )

Holger Kolb \& Henrik Egbert, Eds.

Migrants and Markets: Perspectives from Economics and the Other Social Sciences

2008 (ISBN 9789053566848 )

Ralph Grillo, Ed.

The Family in Question: Immigrant and Ethnic Minorities in Multicultural Europe 2008 (ISBN 978905356869 9) 
Corrado Bonifazi, Marek Okólski, Jeannette Schoorl, Patrick Simon, Eds. International Migration in Europe: New Trends and New Methods of Analysis 2008 (ISBN 978905356894 I)

Maurice Crul, Liesbeth Heering, Eds.

The Position of the Turkish and Moroccan Second Generation in Amsterdam and Rotterdam: The TIES Study in the Netherlands 2008 (ISBN 978908964 o6I I)

Marlou Schrover, Joanne van der Leun, Leo Lucassen, Chris Quispel, Eds. Illegal Migration and Gender in a Global and Historical Perspective 2008 (ISBN 9789089640475 )

Gianluca P. Parolin

Citizenship in the Arab World: Kin, Religion and Nation-State 2009 (ISBN 978908964045 I)

Rainer Bauböck, Bernhard Perchinig, Wiebke Sievers, Eds.

Citizenship Policies in the New Europe: Expanded and Updated Edition 2009 (ISBN 978908964 Io8 3)

\section{IMISCOE Reports}

Rainer Bauböck, Ed.

Migration and Citizenship: Legal Status, Rights and Political Participation 2006 (ISBN 978905356888 o)

Michael Jandl, Ed.

Innovative Concepts for Alternative Migration Policies:

Ten Innovative Approaches to the Challenges of Migration in the 21st Century 2007 (ISBN 978905356990 0)

Jeroen Doomernik, Michael Jandl, Eds.

Modes of Migration Regulation and Control in Europe

2008 (ISBN 978905356689 3)

Michael Jandl, Christina Hollomey, Sandra Gendera, Anna Stepien, Veronika Bilger

Migration and Irregular Work in Austria: A Case Study of the Structure and Dynamics of Irregular Foreign Employment in Europe at the Beginning of the 21st Century

2009 (ISBN 978908964053 6) 
Heinz Fassmann, Ursula Reeger, Wiebke Sievers, Eds.

Statistics and Reality: Concepts and Measurements of Migration in Europe 2009 (ISBN 978908964052 9)

\section{IMISCOE Dissertations}

Panos Arion Hatziprokopiou

Globalisation, Migration and Socio-Economic Change in Contemporary

Greece: Processes of Social Incorporation of Balkan Immigrants in

Thessaloniki

2006 (ISBN 9789053568736 )

Floris Vermeulen

The Immigrant Organising Process: Turkish Organisations in Amsterdam and Berlin and Surinamese Organisations in Amsterdam, 1960-2000 2006 (ISBN 978905356875 ㅇ)

Anastasia Christou

Narratives of Place, Culture and Identity: Second-Generation

Greek-Americans Return 'Home'

2006 (ISBN 978905356878 I)

Katja Rušinović

Dynamic Entrepreneurship: First and Second-Generation Immigrant

Entrepreneurs in Dutch Cities

2006 (ISBN 9789053569726 )

Ilse van Liempt

Navigating Borders: Inside Perspectives on the Process of Human Smuggling into the Netherlands

2007 (ISBN 9789053569306 )

Myriam Cherti

Paradoxes of Social Capital: A Multi-Generational Study of Moroccans

in London

2008 (ISBN 978905356032 7)

Marc Helbling

Practising Citizenship and Heterogeneous Nationhood: Naturalisations in Swiss Municipalities

2008 (ISBN 978908964034 5) 
Inge Van Nieuwenhuyze

Getting by in Europe's Urban Labour Markets: Senegambian Migrants' Strategies for Survival, Documentation and Mobility

2009 (ISBN 978908964050 5)

Nayla Moukarbel

Sri Lankan Housemaids in Lebanon: A Case of 'Symbolic Violence' and 'Everyday Forms of Resistance'

2009 (ISBN 978908964 05I 2)

Jérôme Jamin

L'Imaginaire du Complot: Discours d'Extrême Droite en France et aux Etats-Unis

2009 (ISBN 978908964048 2)

John Davies

'My Name Is Not Natasha': How Albanian Women in France Use

Trafficking to Overcome Social Exclusion (1998-2001)

2009 (ISBN 978905356707 4)

Dennis Broeders

Breaking Down Anonymity: Digital Surveillance of Irregular Migrants in Germany and the Netherlands

2009 (ISBN 978908964 I59 5)

Arjen Leerkes

Illegal Residence and Public Safety in the Netherlands

2009 (ISBN 978908964049 9)

João Sardinha

Immigrant Associations, Integration and Identity: Angolan, Brazilian and Eastern European Communities in Portugal

2009 (9789089640369) 